UNNES

\title{
PEMBELAJARAN MUSIK DENGAN PROGRAM MUSIC WONDERLAND DI HALMAHERA MUSIC SCHOOL SEMARANG
}

\author{
SKRIPSI \\ untuk memperoleh gelar Sarjana Pendidikan \\ oleh: \\ Nama : Didi Hermanto \\ NIM $\quad: 2501411068$ \\ Program Studi : Pendidikan Seni Musik \\ Jurusan $\quad$ : Pendidikan Seni Drama, Tari, dan Musik
}

FAKULTAS BAHASA DAN SENI UNIVERSITAS NEGERI SEMARANG 2017 


\section{PERSETUJUAN PEMBIMBING}

Skripsi yang berjudul "Pembelajaran Musik dengan Program Music Wonderland di Halmahera Music School Semarang" ini telah disetujui oleh dosen pembimbing untuk diajukan ke panitia sidang skripsi Jurusan Pendidikan Seni Drama Tari dan Musik Universitas Negeri Semarang.

Semarang, 15 Agustus 2017

Drs. Slamet Haryono, M. Sn (196610251992031003)

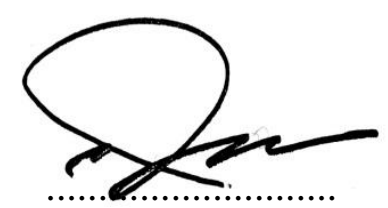

Pembimbing

Dr. Udi Utomo, M. Si (196708311993011001)

Ketua Jurusan Pendidikan Sendratasik 


\section{LEMBAR PENGESAHAN}

Skripsi dengan judul Pembelajaran Musik dengan Music Wonderland di

Halmahera Music School Semarang ini telah disetujui oleh panitia penguji dan disahkan oleh Dekan Fakultas dan Seni pada tanggal Oktober 2017.

Prof. Dr. Agus Nuryatin, M.Hum. (NIP.196008031989011001)

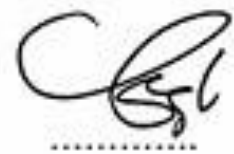

Ketua

Dra. Malarsih, M.Sn. (NIP. 196106171988032001)

Sekretaris

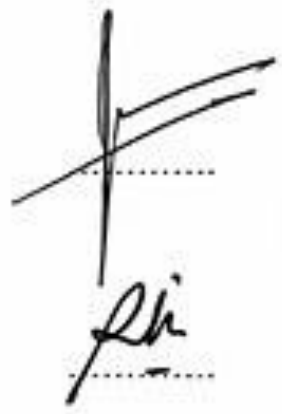

Kusrina Widjajantic, S.Pd., M.A. (NIP.197205182005012001)

Penguji I

M. Usman Wafa, S.Pd., M.Pd. (NIP. 198012042015041001$)$

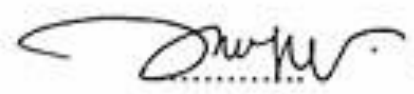
Penguji II

Drs. Slamet Haryono, M.Sn. (NIP. 1966102519920301003)

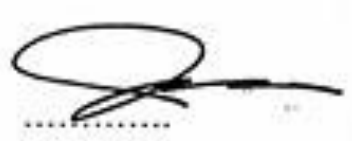
Penguji III/Pembimbing swwocos

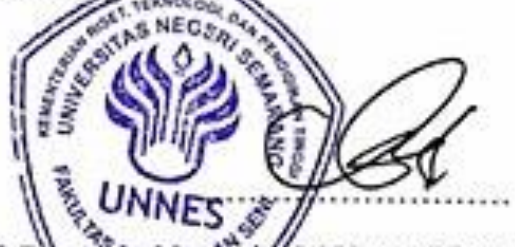

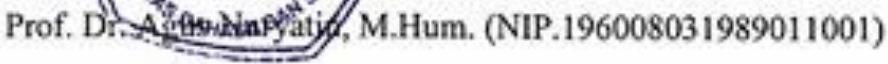

Dekan Fakultas Bahasa dan Seni 


\section{PERNYATAAN}

Dengan ini saya :

Nama : Didi Hermanto

NIM $\quad: 2501411068$

Prodi/Jurusan : Pendidikan Seni Musik/ Pendidikan Seni Drama Tari dan Musik

Fakultas $\quad$ : Bahasa dan Seni Universitas Negeri Semarang

Menyatakan dengan sesungguhnya bahwa skripsi saya yang berjudul "PEMBELAJARAN MUSIK DENGAN PROGRAM MUSIC WONDERLAND DI HALMAHERA MUSIC SCHOOL SEMARANG" saya tulis dalam rangka memenuhi salah satu syarat untuk memperoleh gelar Sarjana Pendidikan, adalah benar-benar merupakan hasil karya saya sendiri yang dihasilkan setelah melakukan penelitian, bimbingan, diskusi dan pemaparan ujian. Semua kutipan baik yang langsung maupun tidak langsung, baik yang diperoleh dari sumber pustaka, media elektronik, wawancara langsung maupun sumber lainnya, telah disertai keterangan mengenai identitas narasumbernya. Demikian pula tim penguji dan pembimbing membubuhkan tanda tangan dalam skripsi ini tetap menjadi tanggung jawab saya secara pribadi.

Demikian pernyataan ini dibuat agar dapat digunakan sebagaimana mestinya.

Semarang, Agustus 2017

Yang membuat pernyataan,

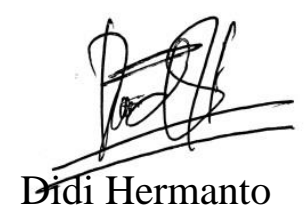




\section{MOTTO DAN PERSEMBAHAN}

Motto:

(1) Sesungguhnya sesudah kesulitan itu ada kemudahan (Al-Insyirah: 6).

(2) Katakanlah yang sebenarnya walaupun pahit (HR. Ibnu Hibban )

Skripsi ini saya persembahkan untuk:

(1) Bapak Purwanto, Ibu Suryati, kakak saya Selly Tri Aryati dan Ikhwan Nur Hakim, adik saya Yogi Heri Nurdi dan Refalita Chandra.

(2) Mertua saya, Bapak Siswanto, dan Ibu Surini.

(3) Istri saya tercinta yang bernama Retno Widowati.

(4) Sahabat dan teman-teman yang saya sayangi.

(5) Keluarga besar Pendidikan Sendratasik UNNES. 


\section{KATA PENGANTAR}

Puji syukur penulis panjatkan kehadirat Allah SWT karena dengan segala limpahan rahmat dan hidayah-Nya sehingga penulis dapat menyelesaikan penyusunan skripsi yang berjudul Pembelajaran Musik dengan Program Music Wonderland di Halmahera Music School Semarang.

Penulis yakin tanpa bantuan dan bimbingan berbagai pihak, skripsi ini tidak akan terwujud. Untuk itu dalam kesempatan ini penulis ingin menyampaikan rasa terimakasih kepada berbagai pihak, yaitu:

1. Prof. Dr. Fathur Rokhman, M.Hum., Rektor Universitas Negeri Semarang yang telah memberikan kesempatan belajar di Universitas Negeri Semarang.

2. Prof. Dr. Agus Nuryatin, M.Hum, Dekan FBS Universitas Negeri Semarang yang telah memberikan ijin penelitian.

3. Dr. Udi Utomo, M.Si., Ketua Jurusan Pendidikan Sendratasik yang memberikan bantuan dan kemudahan dalam penyusunan skripsi.

4. Dosen Pembimbing Drs. Slamet Haryono, M.Sn., yang telah membimbing dengan sabar, memberi saran serta masukan hingga skripsi ini terselesaikan.

5. Halmahera Music School Semarang yang telah memperbolehkan untuk dapat melakukan penelitian di sekolah tersebut.

6. Guru dan staff Halmahera Music School Semarang yang telah menyempatkan waktu untuk bekerjasama dalam penelitian ini.

7. Bapak Purwanto, Ibu Suryati, Adik-adik Seluruh keluarga atas do'a dan dukungannya. 
8. Mertua saya, Bapak Siswanto, dan Ibu Surini.

9. Istri saya tercinta yang bernama Retno Widowati

10. Semua pihak yang tidak dapat disebutkan satu persatu yang telah turut membantu penyelesaian penyusunan skripsi ini.

Penulis menyadari bahwa dalam penyusunan skripsi ini masih jauh dari sempurna. Mengingat keterbatasan penulis, maka penulis mengharapkan kritik dan saran yang bersifat membangun. Harapan penulis, semoga skripsi ini berguna sebagai bahan bacaan dan menambah wawasan.

Semarang, Agustus 2017

Penulis 


\section{SARI}

Hermanto, didi. 2017. Pembelajaran Musik dengan Program Music Wonderland di Halmahera Music School Semarang. Skripsi, Jurusan Pendidikan Seni Drama, Tari, dan Musik. Fakultas Bahasa dan Seni. Universitas Negeri Semarang. Pembimbing: Drs. Slamet Haryono, M. Sn

Kata kunci: Pembelajaran, musik, siswa.

Di Halmahera Music School Semarang terdapat program kelas musik yang memang ditujukan untuk anak usia dini, yaitu Music Wonderland. Program Music Wonderland merupakan pengalaman pertama berkenalan dengan keyboard. Permasalahan pada skripsi ini adalah bagaimana pembelajaran musik pada program Music Wonderland di Halmahera Music School Semarang.

Penelitian ini menggunakan metode kualitatif dengan teknik pengumpulan data melalui observasi, wawancara, dokumentasi, serta analisis secara triangulasi melalui analisis pembelajaran Music Wonderland. Teknik analisis data dilakukan melalui pengumpulan data, penyajian data, reduksi data, dan penarikan kesimpulan.

Hasil penelitian ini menunjukan adanya temuan pada Music Wonderland Halmahera Music School Semarang, siswa yang bisa dikatakan berhasil adalah siswa yang dahulu tidak fokus, mereka bisa fokus, konsentrasi meningkat, memori meningkat, karena dilatih dengan cara diuji kemampuan daya ingat anak dengan menggunakan musik dan gambar. Dengan menggunakan musik dan gambar, otomatis daya imajinasi mereka juga meningkat. Hasil yang sangat membanggakan adalah mereka bisa merasakan tempo, karena diumur 3-4 tahun sangatlah susah untuk mengikuti tempo. Ada juga hal yang mungkin sepele, tetapi manfaatnya luar biasa, yaitu interaksi anak-anak dengan orang tua semakin dekat, karena dalam pembelajaran Music Wonderland, orang tua mendampingi anakanaknya. Music Wonderland menggunakan metode pembelajaran ceramah, demonstrasi, dan drill.

Saran bagi Halmahera Music School Agar pelaksanaan pembelajaran berlangsung lancar, selain menggunakan Teaching Guide sebagai panduan, guru juga harus kreatif dalam mengemas proses pembelajaran agar proses pembelajaran menjadi menyenangkan, siswa menjadi antusias dan siswa bisa lebih menikmati proses pembelajaran. Guru dapat menambahkan media-media lain, sebagai pendukung dalam pembelajaran seperti alat peraga lain yaitu gitar, piano, drum, dan video agar siswa lebih tertarik. 


\section{DAFTAR ISI}

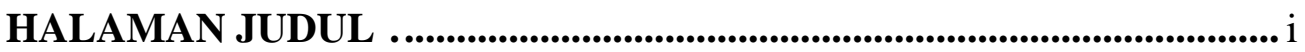

PERSETUJUAN PEMBIMBING ................................................................. ii

LEMBAR PENGESAHAN ........................................................................... iii

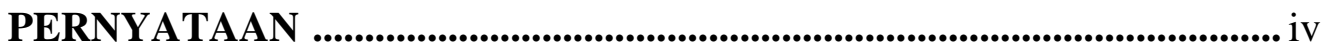

MOTTO DAN PERSEMBAHAN........................................................................ V

KATA PENGANTAR .........................................................................

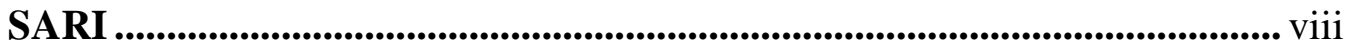

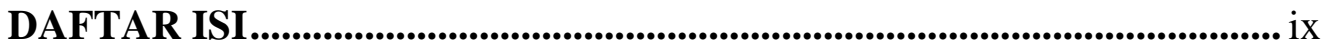

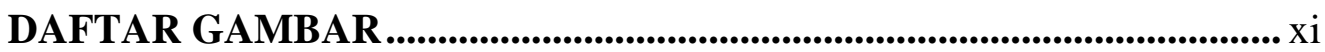

DAFTAR LAMPIRAN ....................................................................... xii

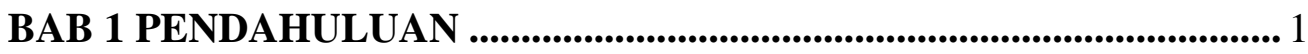

1.1 Latar Belakang Masalah............................................................................................ 1

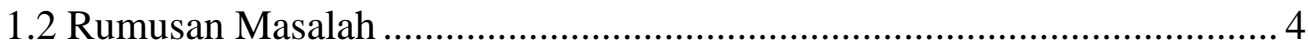

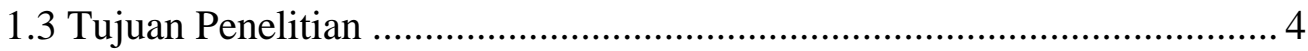

1.4 Manfaat Penelitian ............................................................................ 5

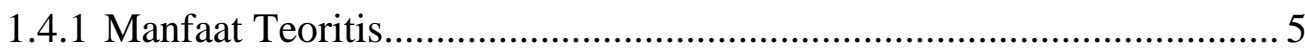

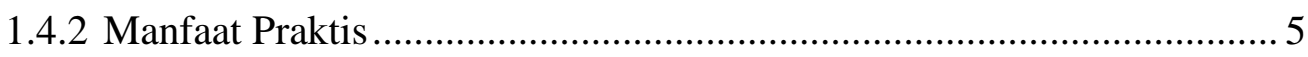

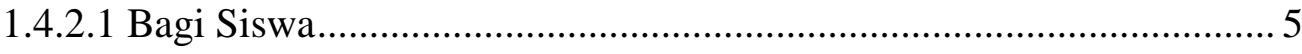

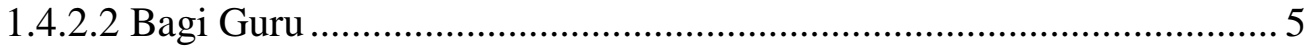

1.4.2.3 Bagi Lembaga Kursus .................................................................... 5

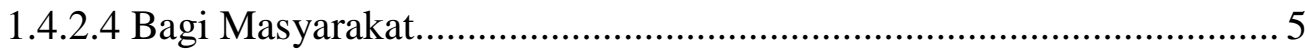

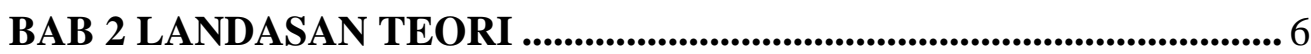

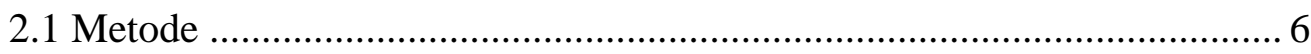

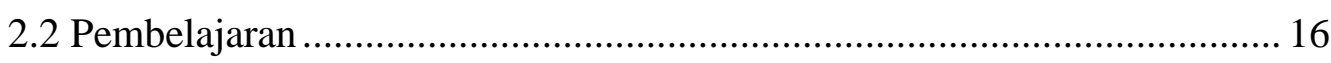

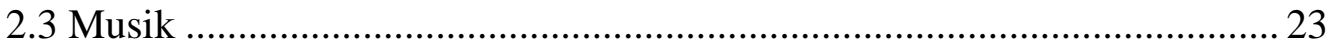

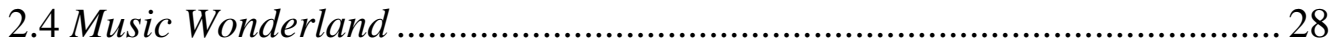

BAB 3 METODE PENELITIAN_............................................................ 31

3.1 Pendekatan Penelitian .......................................................................... 31

3.2 Lokasi Dan Sasaran Penelitian......................................................................... 31 


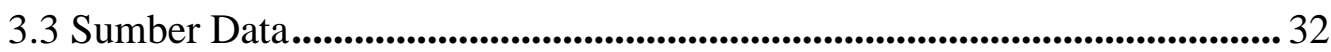

3.4 Teknik Pengumpulan Data........................................................................................... 32

3.5 Metode Pemeriksaan Keabsahan Data ..................................................... 35

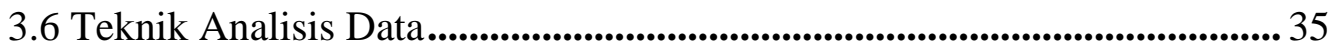

BAB 4 HASIL PENELITIAN DAN PEMBAHASAN ................................. 40

4.1 Gambaran Umum Lokasi Penelitian ............................................................. 40

4.1.1 Berdirinya Halmahera Music School Semarang ............................................ 40

4.1.2 Kondisi Fisik Halmahera Music School Semarang ................................ 43

4.1.3 Sarana Prasarana ....................................................................................... 45

4.2 Pembelajaran Music Wonderland di Halmahera Music School

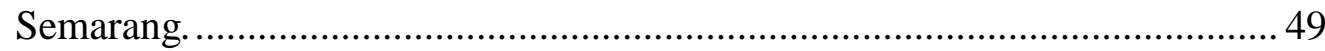

4.2.1 Tujuan- Tujuan Pengajaran Music Wonderland .................................. 49

4.2.2 Langkah langkah Pembelajaran Music Wonderland di Halmahera Music

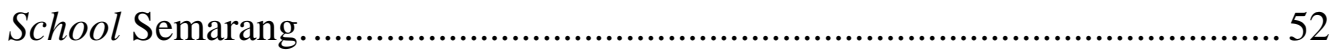

4.2.3 Guru Music Wonderland di Halmahera Music School Semarang.......... 58

4.2.4 Media Pembelajaran Music Wonderland di Halmahera Music School

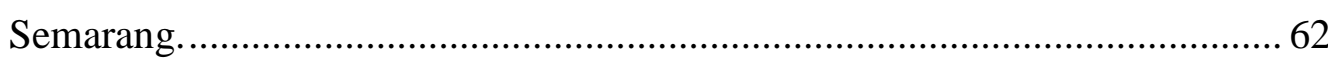

4.2.5 Metode Pembelajaran Music Wonderland di Halmahera Music School Semarang. 65

4.2.6 Evaluasi Pembelajaran Music Wonderland di Halmahera Music School

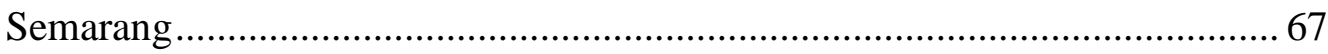

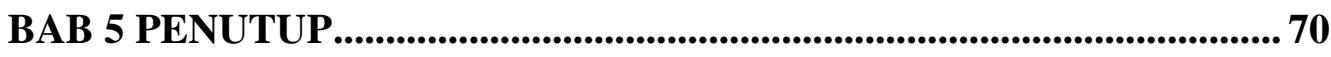

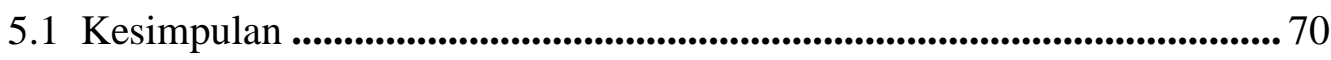

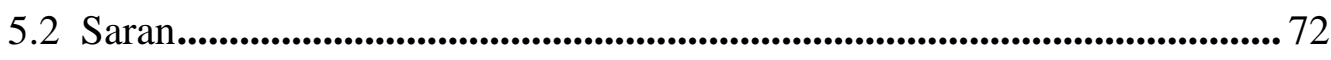

DAFTAR PUSTAKA ........................................................................ 74

LAMPIRAN-LAMPIRAN ....................................................................... 76 


\section{DAFTAR GAMBAR}

Gambar 3.1. Komponen dalam analisis data model interktif

(interactive model)

Gambar. 4.1. Foto tampak depan Halmahera Music School Achmad Yani

Semarang..... 43

Gambar. 4.2. Lokasi Halmahera Music School Achmad Yani Semarang ..... 44

Gambar. 4.3. Ruang tunggu Halmahera Music School Achmad Yani

Semarang 46

Gambar. 4.4. Ruang tunggu Halmahera Music School

Puri Anjasmoro 48

Gambar. 4.5. Foto tentang Music Wonderland ........................................... 52

Gambar 4.6. Lagu Twinkle-Twinkle Little Star ......................................... 56

Gambar 4.7. Lagu Frere Jacques ( Are You Sleeping ) .............................. 56

Gambar 4.8. Ruangan belajar Music Wonderland ..................................... 63

Gambar 4.9. Partitur lagu "Bunyi Drum” ................................................... 64

Gambar 4.10. Halaman yang harus dibuka siswa ketika lagu "Bunyi Drum

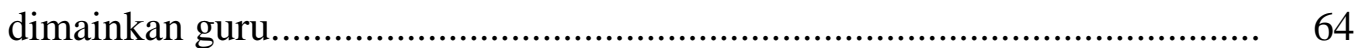

Gambar 4.11. Guru sedang mendemonstrasikan gerakan untuk siswa......... 66

Gambar 4.12. Suasana setelah konser, dan pembagian sertifikat, dan didampingi oleh guru masing-masing 


\section{DAFTAR LAMPIRAN}

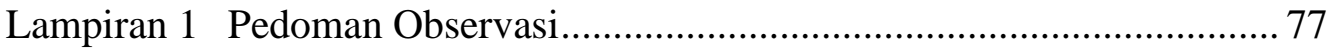

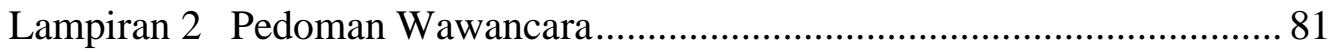

Lampiran 3 Pedoman Wawancara Peneliti dengan General Manager .......... 82

Lampiran 4 Pedoman Wawancara Peneliti dengan Guru............................ 83

Lampiran 5 Pedoman Wawancara Peneliti dengan Siswa ............................. 84

Lampiran 6 Pedoman Dokumentasi .......................................................... 85

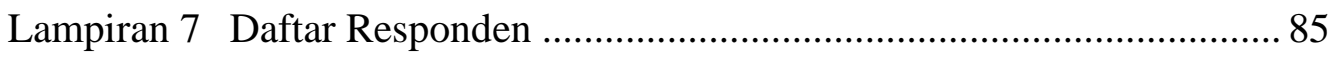

Lampiran 8 Transkrip Wawancara Peneliti dengan General Manager ......... 86

Lampiran 9 Transkip Wawancara Peneliti dengan Guru .............................. 90

Lampiran 10 Transkrip Wawancara Peneliti dengan Siswa .......................... 94

Lampiran 11 Foto-foto Dokumentasi............................................................. 95

Lampiran 12 Surat Keputusan Penetapan Dosen Pembimbing....................... 103

Lampiran 12 Surat Permohonan Izin Penelitian ......................................... 104

Lampiran 12 Surat Keterangan Telah Melakukan Penelitian dari Owner ....... 105 


\section{BAB 1 \\ PENDAHULUAN}

\subsection{Latar Belakang}

Pendidikan merupakan hal yang wajib guna menunjang pembentukan sumber daya manusia yang baik dan terdidik. Pendidikan juga suatu kebutuhan yang sangat penting dalam menopang kehidupan manusia, baik untuk pribadi maupun untuk orang lain. Pada dasarnya, pendidikan merupakan suatu proses yang berlangsung pada seseorang dari keadaan tidak berdaya kepada tingkatan mampu dalam bidangnya. Menurut Saifullah (1980:85), pendidikan adalah suatu proses pertumbuhan di dalam dimana individu diberi pertolongan untuk mengembangkan kekuatan, bakat, dan minatnya.

Menurut Tirtaraharja (1990: 13), pendidikan dibagi menjadi 3 bagian, yaitu pendidikan formal, pendidikan infomal, dan pendidikan non formal. Pendidikan formal adalah pendidikan yang sengaja dirancang dan dilaksanakan dengan aturan-aturan yang ketat, seperti harus berjenjang dan berkesinambungan. Pendidikan informal adalah pendidikan yang terjadi dalam lingkungan keluarga berlangsung alamiah dan wajar. Pendidikan non formal adalah pendidikan dilingkungan masyarakat (salah satunya kursus dan kelompok belajar) tidak dipersyaratkan berjenjang dan berkesinambungan, serta dengan aturan-aturan yang lebih longgar. 
Pendidikan non formal biasanya diselenggarakan pendidikan yang sifatnya melatih ketrampilan tertentu, salah satu jenis pendidikan non formal adalah kursus. Kursus adalah salah satu pendidikan luar sekolah yang terdiri atas sekumpulan warga masyarakat yang memberikan pengetahuan ketrampilan dan sikap mental tertentu dari warga yang belajar (D Sumarno, 1997:208)

Pendidikan non formal merupakan pendidikan luar sekolah yang tidak wajib diikuti oleh setiap orang. Akan tetapi, pendidikan non formal sangat dibutuhkan oleh sebagian orang, dengan tujuan untuk lebih memperluas wawasannya. Salah satu pendidikan non formal yang saat ini diminati oleh sebagian orang baik anak-anak hingga dewasa yaitu pendidikan non formal yang berkecimpung di bidang musik.

Halmahera Music School merupakan Yamaha Showroom \& Music School Semarang. Halmahera Music School terletak di Jalan Ahmad Yani No 193 Semarang, sekolah musik ini diresmikan pada tanggal 1 nopember 2012. Halmahera Music School membuka berbagai les musik dengan menyediakan banyak pilihan, diantaranya adalah: Untuk anak anak ada (1) music fantasi kursus ini untuk anak usia 2 tahun, (2) music wonderland untuk usia 3 tahun, (3) kursus musik yunior, yaitu Junior Music Course (JMC) untuk $4 \& 5$ tahun, (4) Junior Step Fundamental Course (JSFC), (5) kursus Piano, (6) Biola, (7) Drum, (8) Vokal dan (9) Gitar untuk 6 tahun ke atas, (10) kemudian Electone Study Course (ESC) untuk usia 9 tahun ke atas. Sedangkan untuk remaja dan dewasa (12 tahun ke atas) ada (1) kursus alat musik Biola, (2) Saxophone, (3) Vokal, (4) Piano, (5) 
Pop Piano, (6) Flute, (7) Keyboard, (8) Electone, (9) Drum, (10) Gitar, (11) Gitar Listrik, (12) Gitar Akustik, (13)Bass Elektrik dan (14) Recorder.

Halmahera Music School dalam jangka waktu satu tahun mampu menunjukan prestasi membanggakan yaitu, juara 1 "Electone ramai-ramai" tingkat nasional pada acara Yamaha Electone Festival 2013 Indonesia Final. Acara ini telah diselenggarakan dengan meriah pada tanggal 23 Juni 2013 di Nusa Indah Theater Balai Kartini, Jakarta. Dari ajang Yamaha Electone Festival 2013,selain “Electone ramai-ramai”, siswa Halmahera Music School juga mampu mempersembahkan gelar juara 2 nasional Concours A Senior Section atas nama Stevian Arifanto, lalu kemudian ada Concours A Junior Section di tingkat wilayah Jawa Tengah dan DIY. Concours A merupakan cabang kompetisi pada Yamaha Electone Festival dengan ketentuan membuat komposisi musik sendiri, ini tentu bukan merupakan hal yang mudah dan perlu mendapatkan persiapan yang matang.

Sebagian besar siswa-siswi Halmahera Music School adalah anak-anak. Periode anak-anak adalah periode dimana terjadi perubahan emosional yang cepat untuk kebanyakan anak. Mereka sibuk mempelajari ketrampilan baru, meraih tingkat kemandirian yang lebih tinggi. Anak-anak dalam masa ini belajar untuk mengendalikan dan mengarahkan perasaannya. Secara sosial mereka sudah mampu untuk diajak bekerja sama dan menyesuaikan diri dengan orang dewasa. Mereka biasanya mau mengerjakan hal-hal yang diinstruksikan oleh orang dewasa. Maka dari itu, orang tua perlu cermat memilih jenis musik bagaimana yang positif dampaknya dalam menstimulasi otak anak. Halmahera Music School 
terdapat program kelas musik yang memang ditujukan untuk anak usia dini, yaitu Music Wonderland. Program Music Wonderland merupakan pengalaman pertama berkenalan dengan keyboard. Memupuk kecintaan terhadap musik dengan mendengarkan, bernyanyi, merasakan irama dan bermain dengan keyboard. Music Wonderland membantu memperkaya jiwa dan kemampuan pendengaran (Auditory) anak-anak saat bermain musik dengan hati gembira. Kurikulumnya khusus dirancang oleh Yamaha Music Foundation Jepang, agar anak-anak dapat belajar musik dengan sungguh-sungguh dan menikmati aktifitas bermusik yang kreatif.

Berdasarkan latar belakang yang sudah dipaparkan diatas, penulis tertarik untuk meneliti hal yang berkaitan dengan Music Wonderland di Halmahera Music School Semarang dengan judul "Metode Pembelajaran Musik dengan Program Music Wonderland di Halmahera Music School Semarang."

\subsection{Rumusan Masalah}

Berdasarkan latar belakang yang telah dipaparkan, maka rumusan masalah penelitian ini adalah “ Bagaimana Pembelajaran Musik pada Program Music Wonderland di Halmahera Music School Semarang."

\subsection{Tujuan Penelitian}

Berdasarkan permasalahan yang dikemukakan di atas, penelitian ini bertujuan untuk: Mengetahui dan mendeskripsikan metode pembelajaran musik dengan program Music Wonderland di Halmahera Music School. 


\subsection{Manfaat Penelitian}

Manfaat yang bisa diambil dalam penelitian ini adalah:

\subsubsection{Manfaat Teoritis}

1.4.1.1 Dapat digunakan untuk meningkatkan pemahaman mengenai pembelajaran musik dengan program Music Wonderland.

\subsubsection{Manfaat Praktis}

1.4.2.1 Bagi siswa, bisa meningkatkan skill dan progres, serta mempercepat peningkatan kecerdasan emosi anak.

1.4.2.2 Bagi instruktur atau guru, dapat meningkatkan kinerja dalam mengajar siswa pada kursus Music Wonderland.

1.4.2.3 Bagi lembaga kursus, dapat meningkatkan popularitas sekolah musik, sehingga mampu mendapatkan siswa yang lebih banyak lagi, mengharumkan nama sekolah musik atau lembaga kursus, dengan semakin banyaknya siswa yang berprestasi.

1.4.2.4 Bagi masyarakat umum, penelitian ini dapat digunakan sebagai bahan informasi oleh berbagai pihak yang berkepentingan untuk mempelajari Music Wonderland. 


\section{BAB 2}

\section{LANDASAN TEORI}

\subsection{Landasan Teori}

\subsubsection{Pengertian Metode}

Metode menurut Djamaluddin dan Abdullah Aly dalam Kapita Selekta Pendidikan Islam, (1999:114) berasal dari kata meta berarti melalui, dan hodos jalan. Jadi metode adalah jalan yang harus dilalui untuk mencapai suatu tujuan. Sedangkan menurut Depag RI dalam buku Metodologi Pendidikan Agama Islam (2001:19) Metode berarti cara kerja yang bersistem, telah teratur dan terpikir baik-baik untuk memudahkan pelaksanaan suatu kegiatan guna mencapai tujuan yang ditentukan. Berdasarkan definisi di atas, penulis dapat mengambil kesimpulan bahwa metode merupakan jalan atau cara yang ditempuh seseorang untuk mencapai tujuan yang diharapkan.

\subsubsection{Metode Pembelajaran}

Metode mengajar adalah cara atau pendekatan yang digunakan oleh guru untuk mencapai tujuan pembelajaran yang akan direncanakan, baik menggunakan sarana media, dengan melibatkan siswa tanpa sarana maupun keterlibatan secara pasif (Harto Martono, 1995:4). Dalam kegiatan belajar mengajar metode akan mepengaruhi proses pencapaian tujuan. Seperti yang dikemukakan Jamalus (1981:30) yang dimaksud metode dalam kegiatan belajar mengajar adalah seperangkat upaya yang dilaksanakan dan disusun dengan tujuan meniptakan 
suasana kegiatan belajar mengajar yang menguntungkan. Hal ini mengandung arti dalam suatu kegiatan belajar mengajar guru/dosen hendaknya mempersiapkan segala sesuatunya dengan sedemikian rupa sehingga nantinya dapat tercipta situasi belajar mengajar yang menguntungkan.

Metode bagi guru/dosen merupakan alat untuk penyampaian pembelajaran. Penggunanaan metode mengajar yang tepat dan sesuai dengan materi pelajaran yang diajarkan turut menentukan efektifitas dan efisien proses belajar mengajar.

\subsubsection{Macam-macam Metode Pembelajaran}

Metode pembelajaran banyak macam-macam dan jenisnya, setiap jenis metode pembelajaran mempunyai kelemahan dan kelebihan masing-masing, tidak menggunakan satu macam metode saja, mengkombinasikan penggunaan beberapa metode yang sampai saat ini masih banyak digunakan dalam proses belajar mengajar. Menurut Nana Sudjana (dalam buku Dasar-dasar Proses Belajar Mengajar, 1989:78 - 86),terdapat bermacam-macam metode dalam pembelajaran, yaitu Metode ceramah, Metode Tanya Jawab, Metode Diskusi, Metode Resitasi, Metode Kerja Kelompok, Metode Demonstrasi dan Eksperimen, Metode Sosiodrama (role-playing), Metode Problem Solving, Metode sistem regu (team teaching), Metode Latihan (drill), Metode Karyawisata (Field-trip), Metode Survai Masyarakat, dan Metode simulasi.

\subsection{Metode Ceramah}

Metode ceramah adalah penuturan bahan pelajaran secara lisan. Metode ini penggunaannya betul-betul disiapkan dengan baik, didukung dengan alat dan 
media, serta memperhatikan batas-batas kemungkinan penggunaannya. Menurut Ibrahim, (2003: 106) metode ceramah adalah suatu cara mengajar yang digunakan untuk menyampaikan keterangan atau informasi atau uraian tentang suatu pokok persoalan serta masalah secara lisan.

Metode ini seringkali digunakan guru dalam menyampaikan pelajaran apabila menghadapi sejumlah siswa yang cukup banyak, namun perlu diperhatikan juga bahwa metode ini akan berhasil baik apabila didukung oleh metode-metode yang lain, misalnya metode tanya jawab, latihan dan lain-lain. Guru harus benar-benar siap dalam hal ini, karena jika disampaikan hanya ceramah saja dari awal pelajaran sampai selesai, siswa akan bosan dan kurang berminat dalam mengikuti pelajaran, bahkan bisa saja siswa tidak mengerti apa yang dibicarakan oleh gurunya.

Kelebihan metode ceramah adalah guru lebih menguasai kelas, mudah mengorganisasikan tempat duduk/kelas,dapat diikuti oleh jumlah siswa yang besar,mudah mempersiapkan dan melaksanakannya, guru mudah menerangkan pelajaran dengan baik. Tetapi, kelemahan dari metode ceramah yaitu membosankan bila selalu digunakan dan terlalu lama, sulit untuk mengetahui apakah siswa sudah mengerti apa yang telah dijelaskan atau belum, dan menyebabkan mahasiswa menjadi pasif (Djamarah \& Zain, 2010)

\subsection{Metode tanya jawab}

Metode Tanya Jawab adalah metode mengajar yang memungkinkan terjadinya komunikasi langsung yang bersifat two way traffic, sebab pada saat yang sama terjadi dialog antara guru dan siswa. Guru bertanya siswa menjawab 
atau siswa bertanya guru menjawab. Dalam komunikasi ini terlihat adanya hubungan timbal balik secara langsung antara guru dengan siswa.

Metode tanya jawab dapat diartikan sebagai metode mengajar yang memungkinkan terjadinya komunikasi langsung yang bersifat dua arah, sebab pada saat yang sama terjadi dialog antara guru dan siswa. Guru bertanya siswa menjawab atau siswa bertanya guru menjawab Kelebihan metode tanya jawab adalah pertanyaan dapat menarik dan memusatkan perhatian siswa, merangsang siswa untuk melatih dan mengembangkan daya pikir, termasuk daya ingatan, mengembangkan keberanian dan keterampilan siswa dalam menjawab dan mengemukakan pendapat. Tetapi kelemahan metode tanya jawab adalah siswa merasa takut bila guru kurang dapat mendorong siswa untuk berani dengan menciptakan suasana yang tidak tegang, tidak mudah membuat pertanyaan yang sesuai dengan tingkat berpikir dan mudah dipahami siswa, membuang banyak waktu.

\subsection{Metode diskusi}

Metode diskusi adalah bertukar informasi, berpendapat, dan unsurunsur pengalaman secara teratur dengan maksud untuk mendapat pengertian bersama yang lebih jelas dan lebih cermat tentang permasalahan atau topik yang sedang dibahas. Dengan demikian, Metode Diskusi adalah metode pembelajaran berbentuk tukar menukar informasi, pendapat dan unsur-unsur pengalaman secara teratur dengan maksud untuk mendapat pengertian yang sama, lebih jelas dan lebih teliti tentang sesuatu atau untuk mempersiapkan dan merampungkan keputusan bersama. Oleh karena itu diskusi bukanlah debat, karena debat adalah 
perang mulut orang beradu argumentasi, beradu paham dan kemampuan persuasi untuk memenangkan pahamnya sendiri. Dalam diskusi tiap orang diharapkan memberikan sumbangan sehingga seluruh kelompok kembali dengan paham yang dibina bersama.

Kelebihan dari metode diskusi adalah merangsang kreatifitas anak didik dalam bentuk ide, gagasan, prakarsa dan terobosan baru dalam pemecahan masalah, mengembangkan sikap saling menghargai pendapat orang lain, membina untuk terbiasa musyawarah dalam memecahkan suatu masalah. Kelemahan metode diskusi adalah membutuhkan waktu yang panjang, tidak dapat dipakai untuk kelompok yang besar, peserta mendapat informasi yang terbatas dan hanya dikuasai orang-orang yang suka berbicara atau ingin menonjolkan diri.

\subsection{Metode demonstrasi}

Metode demonstrasi dan eksperimen merupakan metode mengajar yang sangat efektif, sebab membantu para siswa untuk mencari jawaban dengan usaha sendiri berdasarkan fakta yang benar. Demonstrasi yang dimaksud ialah suatu metode mengajar yang memperlihatkan bagaimana proses terjadinya sesuatu. Metode demonstrasi adalah metode mengajar yang cukup efektif sebab membantu para siswa untuk memperoleh jawaban dengan mengamati suatu proses atau peristiwa tertentu.

Kelebihan metode demonstrasi yaitu menghindari verbalisme, siswa lebih mudah memahami apa yang dipelajari, proses pengajaran lebih menarik, siswa 
dirangsang untuk aktif mengamati, menyesuaikan antara teori dengan kenyataan dan mencoba melakukannya sendiri. Kelemahan metode demonstrasi adalah memerlukan keterampilan guru secara khusus, membutuhkan waktu yang lama.

\subsection{Metode Eksperimen}

Metode Eksperimen, metode ini bukan sekedar metode mengajar tetapi juga merupakan satu metode berfikir, sebab dalam Eksperimen dapat menggunakan metode lainnya dimulai dari menarik data sampai menarik kesimpulan.Metode eksperimen adalah cara penyajian pelajaran, di mana siswa melakukan percobaan dengan mengalami dan membuktikan sendiri sesuatu yang dipelajari (Djamarah, 2002: 95).

Metode demonstrasi dan eksperimen merupakan metode mengajar yang sangat efektif, sebab membantu para siswa untuk mencari jawaban dengan usaha sendiri berdasarkan fakta yang benar. Demonstrasi yang dimaksud ialah suatu metode mengajar yang memperlihatkan bagaimana proses terjadinya sesuatu. Kelebihan metode eksperimen yaitu membuat siswa lebih percaya atas kebenaran atau kesimpulan berdasarkan percobaan, membina siswa membuat terobosan baru. Kelemahan metode eksperimen adalah cenderung sesuai bidang sains dan teknologi, kesulitan dalam fasilitas, menuntut ketelitian, kesabaran, dan ketabahan, setiap percobaan tidak selalu memberikan hasil yang diharapkan.

\subsection{Metode latihan (drill)}

Metode latihan adalah suatu teknik mengajar yang mendorong siswa untuk melaksanakan kegiatan latihan agar memiliki ketangkasan atau keterampilan yang lebih tinggi dari apa yang dipelajari. Kelebihan metode latihan adalah untuk 
memperoleh kecakapan motoris, untuk memperoleh kecakapan mental, untuk memperoleh kecakapan dalam bentuk asosiasi yang dibuat, pembentukan kebiasaan serta menambah ketepatan dan kecepatan pelaksanaan, pemanfaatan kebiasaan yang tidak membutuhkan konsentrasi, pembentukan kebiasaaan yang lebih otomatis.

Kelemahan metode latihan yaitu menghambat bakat dan inisiatif siswa, menimbulkan penyesuaian secara statis kepada lingkungan, monoton, mudah membosankan, membentuk kebiasaan yang kaku, dapat menimbulkan verbalisme.

\subsection{Metode Pemberian Tugas (Resitasi)}

Metode resitasi adalah metode penyajian bahan di mana guru memberikan tugas tertentu agar siswa melakukan kegiatan belajar. Kelebihan metode resitasi yaitu, merangsang siswa dalam melaksanakan aktivitas belajar baik individual maupun kelompok, dapat mengembangkan kemandirian, membina tanggung jawab dan disiplin siswa, mengembangkan kreatifitas siswa. Untuk kelemahan metode resitasi, sulit dikontrol, khusus tugas kelompok yang aktif siswa tertentu, sulit memberikan tugas yang sesuai perbedaan individu, menimbulkan kebosanan.

\subsection{Metode Karyawisata}

Metode karyawisata (Field-trip), karyawisata di sini berarti kunjungan di luar kelas. Jadi karyawisata di atas tidak mengambil tempat yang jauh dari sekolah dan tidak memerlukan waktu yang lama. Karyawisata dalam waktu yang lama dan tempat yang jauh disebut study tour. Melalui metode ini siswa-siswa 
diajak mengunjungi tempat-tempat tertentu di luar sekolah. Tempat-tempat yang akan dikunjungi dan hal-hal yang perlu diamati telah direncanakan terlebih dahulu, dan setelah kegiatan siswa diminta membuat laporan.

Kelebihan metode karyawisata ialah memiliki prinsip pengajaran modern dengan memanfaatkan lingkungan nyata, membuat relevansi antara apa yang dipelajari dengan kebutuhan di masyarakat, merangsang kreatifitas siswa, bahan pelajaran lebih luas dan aktual. Kelemahan metode karyawisata adalah perlu perencanaan yang matang, perlu koordinasi agar tidak tumpah tindih waktu, mengabaikan unsur studi, kesulitan mengatur siswa yang banyak.

\subsection{Metode Sistem Regu (Team Teaching)}

Metode sistem regu (team teaching), merupakan metode mengajar dua orang guru atau lebih bekerjasama mengajar sebuah kelompok siswa, jadi kelas dihadapi beberapa guru. Sistem regu banyak macamnya, sebab untuk satu regu tidak senantiasa guru secara formal saja, tetapi dapat melibatkan orang-orang luar yang dianggap perlu sesuai dengan keahlian yang kita butuhkan.

\subsection{Metode Sosiodrama}

Metode yang digunakan untuk mengajarkan nilai-nilai dan memecahkan masalah- masalah yang dihadapi dalam hubungan sosial dengan orang-orang di lingkungan keluarga, sekolah maupun masyarakat. Dalam pelaksanaannya siswa diberikan peran tertentu dan melaksanakan peran tersebut serta mendiskusikannya di kelas. (Ibrahim, 2003: 107). 
Kelebihan metode sosiodrama ialah melatih siswa untuk melatih, memahami dan mengingat isi bahan yang akan didramakan, melatih siswa berinisiatif dan berkreatif, memupuk bakat, menumbuhkan dan membina kerjasama, mendapat kebiasaan untuk membagi tanggung jawab, membina tata bahasa siswa. Kelemahan metode sosiodrama, kurang kreatif bagi anak yang tidak ikut dalam drama, memerlukan tempat yang luas, mengganggu kelas lain karena gaduh.

\subsection{Metode Simulasi}

Metode simulasi, simulasi berasal dari kata simulate yang artinya purapura atau berbuat seolah-olah. Kata simulasition artinya tiruan atau perbuatan yang pura-pura. Dengan demikian, simulasi dalam metode mengajar dimaksud sebagai cara untuk menjelaskan sesuatu (bahan pelajaran) melalui proses tingkah laku imitasi atau bermain peran mengenai suatu tingkah laku yang dilakukan seolah-olah dalam keadaan yang sebenarnya.

Kelebihan Metode Simulasi adalah dapat dijadikan sebagai bekal bagi siswa dalam menghadapi situasi yang sebenarnya kelak, baik dalam kehidupan keluarga, masyarakat, maupun menghadapi dunia kerja. Simulasi dapat mengembangkan kreativitas siswa, karena melalui simulasi siswa diberi kesempatan untuk memainkan peranan sesuai dengan topik yang disimulasikan. Simulasi dapat memupuk keberanian dan percaya diri siswa. Memperkaya pengetahuan, sikap dan keterampilan yang diperlukan dalam menghadapi berbagai situasi sosial yang problematis. Simulasi dapat meningkatkan gairah siswa dalam proses pembelajaran. 
Kelemahan Metode Simulasi yaitu pengalaman yang diperoleh melalui simulasi tidak selalu tepat dan sesuai dengan kenyataan di lapangan. Pengelolaan yang kurang baik. sering simulasi dijadikan sebagai alat hiburan, sehingga tujuan pembelajaran menjadi terabaika. Faktor psikologis seperti rasa malu dan takut sering mempenggaruhi siswa dalam melakukan simulasi.

\subsubsection{Kedudukan Metode dalam Belajar Mengajar}

Kegiatan belajar mengajar yang melahirkan interaksi unsur-unsur manusiawi adalah sebagai suatu proses dalam rangka mencapai tujuan pengajaran. Dengan teori dan pengalaman yang dimiliki, dimana digunakan guru untuk mempersiapakan program pengajaran dengan baik dan sistematis. Salah satu usaha yang dilakukan guru adalah bagaimana memahami kedudukan metode sebagai salah satu komponen yang turut ikut mengambil bagian dalam pencapaian keberhasilan kegiatan belajar mengajar (Zain \& Djamarah, 2010). Mengajar diartikan sebagai proses penyampaian informasi atau pengetahuan dari dosen kepada mahasiswa.

Pendapat Smith mengajar adalah menanamkan pengetahuan atau keterampilan (teaching is imparting knowledge or skill). Dari pendapat diatas disimpulkan bahwa mengajar adalah proses penyampaian informasi yang disampaikan guru untuk menanamkan pengetahuan atau keterampilan yang intinya mengarah pada timbulnya keinginan belajar pada siswa (Sanjaya, 2011). Agar proses belajar dalam kelas lebih efektif maka guru harus mampu mengelola proses belajar mengajar dengan baik. 
Kemampuan guru dalam mengelola proses belajar mengajar yaitu kemampuan dalam merencanakan pengajaran, kemampuan melaksanakan proses belajar mengajar dan kemampuan mengevaluasi menilai hasil pengajaran (Sudjana, 2009). Dalam menyusun rencana pengajaran salah satu unsur yang penting yang harus diperhatikan oleh guru adalah pemilihan metode pengajaran.

\subsection{Pembelajaran}

Pembelajaran tidak akan terlepas dari pokok bahasan mengenai hakikat belajar mengajar. Karena dalam setiap proses pembelajaran terjadi peristiwa belajar mengajar. Kegiatan pembelajaran tidak dapat dipisahkan dari kegiatan belajar, karena pembelajaran pada hakikatnya adalah aktivitas belajar antara guru dan murid (Utuh, 1987:9).

\subsubsection{Pengertian Belajar}

Belajar adalah proses yang ditandai dengan adanya perubahan pada diri seseorang. Perubahan sebagai hasil belajar dapat terwujud dalam berbagai bentuk, antara lain: perubahan pengetahuan, pemahaman, persepsi, ketrampilan, kecakapan, kebiasaan dan perubahan aspek-aspek lain yang ada dalam diri individu. Perubahan bersifat konstan dan berbekas (Winkel, 1989:36)

Menurut Muhibin Syah (1995:93) belajar adalah kegiatan yang berproses dan merupakan unsur yang sangat fundamental dalam setiap penyelenggaraan jenis dan jenjang pendidikan. Teori belajar menurut Syah (1996:115), berarti perubahan yang terjadi dalam proses belajar adalah berkat pengalaman atau 
praktik yang dilakukan secara sengaja dan disadari atau dengan kata lain bukan secara kebetulan.

Pengertian teori belajar secara khusus menurut Darsono, dkk (2000: 1518) dibagi menjadi empat aliran psikologis, yaitu:

\subsubsection{Belajar menurut aliran Behavioristik}

Kaum behavioris berasumsi bahwa manusia adalah makhluk pasif, tidak mempunyai potensi psikologis yang berhubungan dengan kegiatan belajar, antara lain: pikiran persepsi, motivasi dan emosi dengan asumsi seperti manusia dapat direkayasa sesuai tujuan yang hendak dicapai, yang terpenting dalam belajar, adalah pemberian stimulus yang berakibat terjadinya tingkah laku yang dapat diobservasi dan diukur. Oleh karena itu, stimulus harus dipilih sesuai dengan tujuan, kemudian diberikan secara berulang-ulang, sehingga terjadi respon yang mekanistik. Supaya tingkah (respon) yang diinginkan terjadi, diperlukan latihan dan hadiah atau penguatan, maka peristiwa belajar sudah terjadi. Artinya sudah terjadi perubahan dari "belum terlihat respon" menjadi "sudah terlihat respon". Kaum behavioris tidak meyakini adanya perubahan tingkah laku abstrak, misalnya perubahan dalam pemahaman (mengerti) perubahan dalam persepsi (pandangan satu obyek), karena perubahan semacam itu terkadang dapat disaksikan dan diukur.

\subsubsection{Belajar menurut aliran Humanistik}

Sumanto ( dalam Darsono, 2000: 18), berpendapat penganut aliran humanistik beranggapan bahwa tiap orang dapat menentukan langkah sendiri 
tingkah lakunya. Orang bebas memilih sesuai kebutuhannya, tidak terkait pada lingkunganya. Dengan demikian, tujuan pendidikan adalah membantu masingmasing individu untuk mengenal dirinya sendiri sebagai manusia yang unik dan membantunya dalam mewujudkan potensi-potensi yang ada pada diri masingmasing.

\subsubsection{Belajar menurut aliran Gestalt}

Belajar menurut aliran Gestalt adalah bagaimana seseorang memandang suatu obyek (persepsi) dan kemampuan mengatur atau mengorganisir obyek yang dipersepsi (khususnya yang kompleks), sehingga menjadi suatu bentuk (struktur) yang bermakna atau mudah dipahami. Kalau orang sudah mampu mempersepsi suatu obyek (stimulus) menjadi suatu Gestalt, orang itu akan memperoleh "insight" (pemahaman). Kalau pemahaman sudah terjadi, berarti proses belajar sudah terjadi.

\subsubsection{Belajar menurut aliran kognitif}

Ahli-ahli yang menganut aliran kognitif berpendapat bahwa belajar adalah peristiwa internal, artinya belajar baru dapat terjadi bila ada kemampuan dalam diri orang yang belajar. Kemampuan tersebut adalah kemampuan mengenal yang disebut dengan istilah kognitif. Berbeda dengan konsep belajar Behavioristik, yang mengandalkan pada lingkungan (stimulus), penganut aliran kognitif memandang orang yang belajar sebagai makhluk yang memahami obyek-obyek yang berbeda di luar dirinya, dan mempunyai kemampuan untuk melakukan suatu tindakan sebagai akibat pemahamannya itu. Agar terjadi perubahan, harus terjadi 
proses berpikir terlebih dahulu dalam diri seseorang, yang kemudian menimbulkan respon berupa tindakan.

Berkaitan dengan hal tersebut di atas, ada beberapa orang yang dituntut mampu mengkoordinasi proses belajar, salah satunya ialah guru. Kegiatan atau usaha yang dilakukan oleh guru dalam mengkoordinasi proses belajar disebut pembelajaran. Pembelajaran lebih dari sekedar pengajaran, yaitu guru dan murid sama-sama belajar.

\subsubsection{Pengertian mengajar}

Setiap siswa pasti membutuhkan bantuan. Artinya siswa tidak boleh dibiarkan begitu saja, sehingga akan berkembang dan tumbuh seorang diri. Mereka perlu dibimbing ke arah kedewasaan. Menurut Sadirman (1986: 46), mengajar pada dasarnya merupakan usaha untuk menciptakan kondisi atau sistem lingkungan yang mendukung dan memungkinkan untuk berlangsungnya proses belajar.

Mengajar adalah suatu usaha guru untuk memimpin siswa kearah perubahan, dalam arti kemajuan proses perkembangan intelektual pada khususnya ( Ahmadi, 1985:32-33). Menurut Alvin (dalam Roestijah, 1982: 13) mengajar merupakan aktivitas guru yang membimbing siswa dapat mengubah dan mengembangkan skill dan attitude ( bakat dan kemampuan), idea (cita-cita), appreciaton (penghargaan), dan knowledge (pengetahuan). Secara lebih terperinci menurut Tarigan (dalam Iswaji dan Purwanto, 1989: 148) mengemukakan unsur 
yang berperan dalam belajar mengajar yaitu unsur siswa, guru, tujuan, materi, metode, media, dan evaluasi.

Mengajar bukan lagi suatu penyampaian belaka, namun lebih luas lagi, bahwa mengajar merupakan suatu aktifitas memadukan secara integrative dari sejumlah komponen yang terkandung dalam perbuatan. Mengajar dalam rangka membimbing anak didik kearah perubahan tingkah laku sesuai kebutuhan individu atau kebutuhannya sebagai anggota masyarakat.

\subsubsection{Pengertian pembelajaran}

Pada dasarnya, pembelajaran adalah proses yang diselenggarakan oleh guru untuk membelajarkan siswa dalam belajar, bagaimana belajar memperoleh dan memproses pengetahuan, ketrampilan, dan sikap (Dimjati dan Mudjiono, 1994:2). Pembahasan mengenai hakikat pembelajaran tidak akan terlepas dari pembahasan mengenai belajar dan mengajar, karena dalam setiap proses pembelajaran terjadi peristiwa belajar mengajar. Pendapat tersebut sesuai dengan pendapat Utuh (1987:9) yang menyatakan bahwa pembelajaran pada hakikatnya adalah aktivitas belajar dan mengajar antara guru dan siswa dibawah interaksi edukatif.

\subsubsection{Tujuan pembelajaran}

Pembelajaran adalah suatu kegiatan yang bertujuan. Tujuan ini harus searah dengan tujuan belajar siswa. Tujuan belajar siswa adalah mencapai perkembangan optimal, yang meliputi aspek-aspek kognitif, afektif, dan psikomotor. Dengan demikian, tujuan pembelajaran adalah agar siswa mencapai 
perkembangan optimal dalam ketiga aspek terebut. (Tim MKDK IKIP Semarang, 1996:12).

\subsubsection{Materi Pembelajaran}

Dalam penyampaian materi pembelajaran guru, hendaknya perlu memperhatikan secara sistematis dengan mempertimbangkan urutan keluasan materi dan kedalaman materi (Ekosiswoyo, 1996:49). Ada beberapa hal yang perlu diperhatikan bagi guru/dosen pada waktu menyajikan materi pembelajaran. Menurut Caroll (dalam Ekosiswoyo, 1996:10), kemampuan siswa menguasai materi tertentu berhubungan dengan jumlah waktu yang dipersyaratkan. Dalam arti jika siswa diberi waktu dengan tingkat kesulitan materi pembelajaran yang dipelajari, dan berpartisipasi di dalam kegiatan yang direncanakan untuk mempelajari materi pembelajaran tersebut sesuai dengan tingkat yang diinginkan.

Di Halmahera Music School Semarang, pembelajaran Music Wonderland memiliki tujuan yang jelas untuk mencapai hasil belajar yang maksimal. Untuk pembelajaran Music Wonderland, dikhususkan untuk anak-anak berusia 4 (empat) tahun.

\subsubsection{Evaluasi Pembelajaran}

Evaluasi pembelajaran bagian integral dari proses pendidikan, karena dalam proses pendidikan guru perlu mengetahui seberapa jauh proses belajar dan mengajar telah mencapai tujuan yang telah ditetapkan (Tim MKDK IKIP Semarang, 1996: 63) 
Dalam konteks belajar, istilah evaluasi menujukan suatu kegiatan untuk menentukan nilai pencapaian hasil belajar dengan mengetahui hasil pencapaian hasil belajar siswa.

\subsubsection{Siswa}

Siswa atau murid adalah salah satu komponen dalam pengajaran, disamping faktor guru, tujuan dan metode pengajaran. Sebagai salah satu komponen, maka dapat dikatakan bahwa murid adalah komponen yang terpenting diantara komponen lainnya. Pada dasarnya, murid adalah unsur penentu dalam proses belajar mengajar, sebab muridlah yang membutuhkan pengajaran, guru hanya berusaha memenuhi kebutuhan yang ada pada murid (Oemar Hamalik, 2001: 99-100)

\subsubsection{Guru}

Peranan guru dalam proses belajar mengajar sangat penting yaitu sebagai moderator, sebagai pengelola kelas, sebagai ahli media, sebagai evaluator dan harus dapat menyelenggarakan dan menilai program pengajaran. Tanggung jawab guru yang terpenting ialah merencanakan dan menuntut murid-murid melakukan kegiatan-kegiatan belajar guna mencapai pertumbuhan dan perkembangan yang diinginkan (Oemar Hamalik, 2001:127).

Dalam proses pembelajaran ada beberapa komponen yang sangat mempengaruhi sekali dalam proses pembelajaran.

\subsubsection{Komponen pembelajaran:}

\subsubsection{Kurikulum}


Kurikulum adalah sejumlah pengalaman belajar yang diberikan dalam usaha mencapai suatu tujuan tertentu. Menurut William B. Ragan dalam Soetopo (1982: 56-57) kurikulum tidak hanya berupa hal-hal yang ada dalam buku teks, dalam mata pelajaran atau rencana guru, kurikulum meliputi lebih daripada isi, bahan pelajaran, hubungan kemanusiaan dengan kelas, metode mengajar, prosedur penilaian, yang kesemuanya itu dalam kurikulum.

\subsubsection{Tujuan}

Pembelajaran adalah suatu kegiatan yang bertujuan. Tujuan ini harus searah dengan tujuan belajar siswa tujuan belajar siswa adalah mencapai perkembangan optimal, yang meliputi aspek-aspek kognitif, afektif, psikomotor. Dengan demikian, tujuan pembelajaran adalah agar siswa mencapai perkembangan opitmal dalam ketiga aspek tersebut (TIM MKDK IKIP Semarang, 1996: 12)

\subsubsection{Musik}

Menurut Kamus Besar Bahasa Indonesia (2005:76), musik adalah ilmu atau seni munyusun nada atau suara di urutan, kombinasi, dan hubungan temporal untuk menghasilkan komposisi (suara) yang mempunyai kesatuan dan kesinambungan, selain itu musik bisa dikatakan sebagai nada atau suara yang disusun sedemikian rupa sehingga mengandung irama, lagu dan keharmonisan (terutama yang menggunakan alat-alat yang dapat menghasilkan bunyi-bunyi itu).

Seni merupakan salah satu bagian terpenting dari kehidupan manusia karena berhubungan dengan insting dan serta dapat berbentuk bakat, karakter dan idealisme seseorang. Pada dasarnya, seni adalah kebutuhan rohani karena seni 
mengutamakan keindahan, dan keindahan selalu berhubungan dengan kepuasan batin. Seperti pendapat Kesumah (1995: 2) yang mengemukakan bahwa walaupun tidak merupkan dasar eksistensi hidup manusia, akan tetapi seni (musik atau lagu) adalah sebagian dasar sosial dan cultural manusia itu sendiri.

Musik adalah cabang seni abstrak yang berbentuk suara dan terdiri dari unsur-unsur ritme, melodi, harmoni dan warna suara (Limantara, 1988:1). Menurut Jamalus (1988:1) musik adalah suatu hasil karya seni bunyi dalam bentuk lagu atau komposisi musik yang mengungkapkan pikiran dan perasaan penciptanya melalui unsur-unsur musik, yaitu irama, melodi, bentuk atau struktur lagu dan ekspresi sebagai satu kesatuan.

Seperti kita ketahui, biasanya musik memang tampil berupa rangkaian nada, baik dalam vokal ataupun instrumental. Namun, bukanlah musik dapat pula dihasilkan hanya dengan tepuk tangan atau dengan dua potong kayu yang saling dipukulkan. Dalam hal ini keduanya merupakan alat musik yang tidak bernada, meskipun ada bunyinya. Dalam kaitan dengan wawasan seni, semua sumber seni, tidak semua sumber seni yang indah dapat dianggap sebagai karya seni, sebab yang disebut seni adalah jika bunyi itu berupa hasil olah pikir, akal, budi, dan perasaan manusia. Seorang pakar seni mejadi 3 cabang yaitu: (1) Seni yang diminati dengan media pendengaran (auditory art) adalah seni musik, (dengan nada), seni sastra (dengan kata), dan seni suara (dengan nada dan kata), (2) Seni yang dinikmati dengan media penglihatan (visual) ada dua yaitu yang dilihat dari bentuk dan mata, dengan memanfaatkan unsur-unsur garis, warna, bentuk, irama dan cahaya yaitu seni rupa dan seni patung (tanpa gerak) dan seni pantomim 
(dengan gerak), (3) Seni yang dinikmati dengan media penglihatan dan pendengaran (Auditory Visual Art) yaitu seni tari yang mengandug unsu gerak dan nada, seni drama dan opera mengandung unsur gerak, kata, dan visual.

Faktor berikutnya yang dikemukakan adalah harmoni, yaitu keselarasan sesuai dengan lagunya. Pendapat Sylado (1986: 12-13) yang mengatakan bahwa musik bukan sekedar bunyi dari suara saja. Di dalam bunyi dan suara, ada tata tertib yang mewujudkannya menjadi indah, baik dan betul, yaitu unsur nada, unsur irama, dan unsur keselarasan. Dalam istilah lazim unsur nada disebut melodi, unsur irama disebut ritme, dan unsur keselarasan disebut harmoni.

\subsubsection{Unsur-Unsur Musik}

Unsur-unsur musik terdiri dari beberapa kelompok yang secara bersama merupakan satu kesatuan membentuk suatu lagu atau komposisi musik. Semua unsur musik tersebut berkaitan erat dan sama-sama mempunyai peranan penting dalam sebuah lagu.

Menurut Jamalus (1988: 7), pada dasarnya unsur-uunsur musik dapat dikelompokan atas: a) Unsur-unsur pokok yaitu harmoni, melodi, atau struktur lagu. b) Unsur-unsur ekspresi yaitu tempo, dinamik, dan warna nada kedua unsur pokok musik tersebut merupakan satu kesatuan yang tidak dapat dipisahkan.

Penjelasan unsur-unsur musik tersebut dapat dijelaskan sebagai berikut:

\subsubsection{Harmoni}

Harmoni adalah keselarasan bunyi yang merupakan gabungan dua nada atau lebih yang berbeda tinggi rendahnya (Jamalus, 1988:35). Rochaeni (1989:34) 
mengartikan harmoni sebagai gabungan beberapa nada yang dibunyikan secara serempak atau arpegic (berurutan) walau tinggi rendah nada tidak sama tapi selaras kedengarannya dan mempunyai satu kesatuan yang bulat. Sebuah lagu dapat terdiri atas satu kalimat atau beberapa kalimat musik. Jumlah kalimat ini bermacam-macam, seperti juga kalimat puisi; dua, tiga, empat, dan lain sebagainya. Lagu yang sederhana terdiri atas satu kalimat musik disebut bentuk lagu, satu bagian yang didalamnya berisikan kalimat tanya dan kalimat jawab. Biasanya lagu yang sederhana ini terdiri atas delapan birama.

\subsubsection{Irama}

Irama dapat diartikan sebagai bunyi atau sekelompok bunyi dengan bermacam-macam panjang pendeknya not dan tekanan atau aksen pada not. Irama dapat pula diartikan sebagai ritme, yaitu susunan panjang pendeknya nada tegantung pada nilai titi nada. Jamalus (1988:8) mengartikan irama dalam musik terbentuk dari sekelompok bunyi dengan bermacam-macam lama waktu dan panjang irama tersusun ataas dasar ketukan atau ritme yang berjalan secara teratur. Ketukan tersebut terdiri dari ketukan kuat dan ketukan lemah.

Menurut Sudarsono (1991: 14) dalam praktek sehari-hari irama mempunyai dua pengertian. Pengertian pertama irama diartikan sebagai pukulan atau ketukan yang selalu tetap dalam suatu lagu berdasarkan pengelompokan pukulan kuat dan pukulan lemah. Pengertian kedua irama diartikan sebagai pukulan-pukulan berdasarkan panjang pendek atau nilai nada-nada dalam suatu lagu. sebuah lagu baik vokal maupun instrumental merupakan alur bunyi yang teratur. Dalam lagu tersebut terdapat adanya suatu pertentangan bunyi antara 
bagian yang bertekanan ringan dan bagian yang bertekanan berat. Pertentangan bunyi yang teratur dan selalu berulang-ulang tersebut dinamakan irama atau ritme (Sukohardi, 1998:16).

Irama dalam bentuk musik terbentuk dari kelompok bunyi dan diam dengan bermacam-macam panjang pendeknya nada pada tekanan atau aksen pada not. Untuk menulis bunyi dan diam dengan bermacam-macam panjang pendeknya, digunakan dengan notasi irama dengan bentuk dan nilai tertentu. Untuk tekanan atau aksen pada not diperlukan tanda birama.

\subsubsection{Melodi}

Melodi adalah susunan rangkaian nada (bunyi dengan getaran teratur) yang terdengar berurutan serts bersama dengan mengungkapkan suatu gagasan (Jamalus, 1998:16)

\subsubsection{Bentuk Lagu / Struktur Lagu}

Bentuk lagu atau struktur lagu adalah susunan atau hubungan antara unsurunsur musik dalam suatu lagu, sehingga menghasilkan komposisi lagu yang bermakna (jamalus, 1988: 35).

\subsubsection{Tanda Tempo dan Dinamika}

Tanda tempo adalah kecepatan dalam memainkan lagu dan perubahanperubahan dalam kecepatan lagu tersebut. Tanda tempo dibagi dalam tiga bagian yaitu, tempo lambat, sedang dan tempo cepat. Kuat lemahnya suara dalam suatu lagu atau musik disebut dinamik yang dilambangkan dengan berbagai macam lambang, antara lain: forte, mezzo forte, piano, dsb. Warna nada menurut Jamalus 
(1988: 40), didefinisikan sebagai ciri khas bunyi yang terdengar bermacammacam dan dihasilkan oeh bahan sumber atau bunyi-bunyi yabg berbeda.

\subsubsection{Ekspresi}

Ekspresi adalah suatu ungkapan pikiran dan perasaan yang mencakup tempo, dinamik, dan warna nada dari unsur-unsur pokok musik yang diwujudkan oleh seniman musik penyanyi yang disampaikan pada pendengarnya (Jamalus, 1988:38). Dengan begitu unsur ekspresi merupakan unsur perasaan yang terkandung di dalam kalimat bahasa maupun kalimat musik yang melalui kalimat musik inilah pencipta lagu atau penyanyi mengungkapkan rasa suatu lagu.

\section{$2.4 \quad$ Music Wonderland}

Music Wonderland adalah sebuah kurikulum yang dirancang oleh Yamaha Music Foundation yang berpusat di Jepang yang diperuntukkan anak usia 3(tiga) sampai 4 tahun, mengingat perkembangan zaman dan kemajuan teknologi dimana kemampuan anak-anak sekarang berkembang dengan lebih pesat. Tujuan dibentuknya kurikulum tersebut yaitu untuk memperkenalkan musik pada anakanak untuk melatih indera. Anak-anak yang bergabung dalam Musik Wonderland wajib berusia 3 sampai 4 tahun. Bila usia belum mencukupi, maka diwajibkan mengikuti program Musik Wonderland pada periode selanjutnya hingga umur anak tersebut telah memenuhi syarat.

Anak-anak dalam tahap ini dikatakan, bahwa anak-anak pada usia tiga atau empat tahun memiliki dasar emosional yang hampir sempurna. Dengan kata lain, ini adalah tahap terpenting dalam hidup mereka untuk membentuk kepribadian. 
Oleh karena itu pengalaman yang mereka dapatkan dalam tahap ini akan sangat berpengaruh dalam kehidupan masa depan mereka. Setelah mengetahui hal ini, keputusan setiap orang tua dalam memberikan pendidikan musik pada anak di tahap ini akan sangat berperan penting.

2.4.1 Kurikulumnya khusus dirancang oleh Yamaha Music Foundation Jepang, agar anak-anak dapat belajar musik dengan sungguh-sungguh dan menikmati aktifitas bermusik yang kreatif.

\subsubsection{Mendengar}

Pada masa ini kemampuan pendengaran anak akan berkembang dengan pesat. Kemampuan dasar sensibilitas terhadap suara akan berkembang melalui pengalaman mendengar melodi, ekspresi atau nuansa suara seperti: tempo, irama, harmoni dan lain-lain.

\subsubsection{Bernyanyi.}

Bernyanyi merupakan cara yang terjangkau untuk mengekspresikan perasaan sendiri melalui musik secara dinamik dan memperkaya jiwa melalui pengalaman bernyanyi berbagai jenis lagu seperti lagu yang menyenangkan, lagu hubungan orang tua dan anak dll. Anak-anak juga belajar bernyanyi dengan do-re$m i$.

\subsubsection{Merasakan irama}

Anak-anak dapat memperluas dunia musiknya di masa depan dengan menguasai sense irama yang diperlukan untuk bermusik dengan belajar mengekpresikan irama dengan berbagai style menggunakan tubuh dan percussion.

\subsubsection{Bermain-main dengan keyboard.}


Perasaan berpartisipasi pada musik secara aktif akan berkembang melalui pengalaman mengekspresikan suara seperti bintang, jam, dan sebagainya menggunakan beragam suara electone, "memainkan keyboard" dengan senang hati, anak-anak dengan sendirinya dapat mendengar dan mengekspresikan image dan nuansa suara. Pengalaman tersebut akan memperkaya permainan dan ekspresi musik di masa depan.

Masa belajar Music Wonderland berjalan selama satu tahun, dimana penerimaan siswa dimulai pada bulan Februari dan Agustus. Waktu belajar dalam satu tahun tersebut, siswa memperoleh tiga puluh enam pertemuan atau seminggu sekali. Setiap pertemuan, waktu pembelajaran berjalan lima puluh menit. Format belajar di kelas adalah berupa kelompok yang berjumlah sepuluh anak atau lebih. Dalam pembelajaran Music Wonderland, anak-anak didampingi penuh oleh orang tua, karena orang tua punya peranan penting dalam pembelajaran ini. Tugas orang tua adalah membantu anak menerima pesan yang disampaikan oleh guru, karena tidak setiap anak dapat langsung menerima apa yang disampaikan oleh guru. 


\section{BAB 3}

\section{Metode Penelitian}

\subsection{Pendekatan Penelitian}

Penelitian ini merupakan jenis kualitatif dengan menggunakan pendekatan deskriptif kualitatif. Penelitian kualitatif adalah penelitian yang mendiskripsikan suatu permasalahan yang di dalamnya terdapat pengkajian untuk menyelesaikan permasalahan yang ada berdasarkan data-data valid berupa kata-kata yang ditulis.

Moleong (2006 : 6) mengatakan bahwa penelitian deskriptif kualitatif adalah penelitian yang bermaksud untuk memahami fenomena tentang apa yang dialami oleh subyek penelitian misalnya perilaku, persepsi, motivasi, tindakan dan lain-lain, secara holistik dan dengan cara diskripsi dalam bentuk kata-kata dan bahan, pada suatu konteks khusus yang alamiah dan dengan memanfaatkan berbagai metode alamiah.

Peneliti menggunakan metode penelitian kualitatif karena peneliti ingin mendeskripsikan pembelajaran musik dengan program Music Wonderland di Halmahera Music School Semarang.

Penelitian menggunakan metode penelitian kualitatif, dalam hal ini yang akan diteliti adalah program Music Wonderland bagi anak usia dini di Halmahera Music School Semarang.

\subsection{Lokasi dan Sasaran Penelitian}

\subsubsection{Lokasi Penelitian}

Penelitian ini dilakukan di Halmahera Music, Yamaha Showroom \& Music School Semarang, yang beralamat di jalan Achmad Yani No 193 Semarang. 


\subsubsection{Sasaran Penelitian}

Sasaran penelitian ini adalah pembelajaran musik dengan program music wonderland di Halmahera Music School Semarang.

\subsection{Sumber Data}

Data atau informasi yang diperlukan maka ditentukan sumber data atau informasi yang terdiri dari Teaching Guide (panduan mengajar) termasuk di dalamnya adalah kurikulum, kemudian narasumber yang memiliki pengetahuan atau wawasan yang memadai tentang informasi yang diperlukan. Narasumber yang dimaksud adalah: (1) Anak dari pemilik Halmahera Music School yaitu Ibu Sherly yang sekaligus sebagai General Manager Halmahera Music School, (2) Guru Electone senior di Halmahera Music School dan juga sebagai dokter di Semarang yaitu Bapak Hendro, (3) Siswa dari Pak Hendro yang mengikuti program Music Wonderland di Halmahera Music School.

\subsection{Teknik Pengumpulan Data}

Menurut Rachman (1993: 57) dalam metode pengumpulan data diperlukan teknik, prosedur, dan alat serta kegiatan yang dapat diandalkan, karena metode pengumpulan data adalah suatu proses pengadaan data untuk keperluan penelitian. Data yang diperoleh harus valid, relevan, jelas dan akurat. Penelitian kualitas ini, data dikumpulkan dengan metode:

\subsubsection{Obsevasi / Pengamatan}

Observasi diartikan sebagai pengamatan dan pencatatan secara sistematik terhadap gejala-gejala yang nampak pada objek-objek atau sasaran penelitian (Rachman, 1993:71). Menurut Moleong (dalam Sumaryanto, 2007:101) 
Pengamatan dibagi menjadi 2 jenis yaitu pengamatan terbuka dan pengamatan tertutup.

Pengamatan terbuka diketahui oleh subyek sehingga subyek dengan sukarela memberikan kesempatan kepada pengamat untuk mengamati peristiwa yang terjadi dan mereka menyadari bahwa ada orang lain yang sedang mengamati mereka. Sebaliknya, pada pengamatan tertutup, pengamat beroperasi tanpa diketahui oleh subyeknya. Penelitian kualitatif ini menggunakan penelitian terbuka.

Hal-hal yang diobservasi dalam penelitian ini meliputi tempat pembelajaran Music Wonderland, siswa MW (Music Wonderland) / anak usia dini, pengajar, materi ajar, dan proses pembelajaran Music Wonderland dari guru kepada para siswa di Halmahera Music School.

\subsubsection{Wawancara}

Wawancara adalah percakapan dengan maksud tertentu (Moleong dalam Sumaryanto, 2007: 101). Menurut Nasution (1996: 89), wawancara adalah salah satu bentuk komunikasi verbal jadi semacam percakapan yang bertujuan untuk memperoleh informasi. Peneliti menggunakan wawancara berstruktur dan tidak terstruktur. Wawancara berstruktur adalah jenis wawancara yang telah dipersiapkan secara sistematis dan terstruktur oleh pewawancara dengan jelas biasanya secara tertulis. Wawancara tidak terstruktur adalah wawancara yang bebas dimana peneliti tidak menggunakan pedoman wawancara yang telah tersusun secara sistematis dan lengkap untuk mengumpulkan datanya. Pedoman wawancara yang digunakan hanya berupa garis-garis besar permasalahan yang 
akan ditanyakan. Dari kombinasi dari wawancara berstruktur dan tidak terstruktur, diharapkan peneliti bisa mendapatkan informasi yang lebih lengkap dan valid.

Penelitian ini sebagai narasumber adalah anak dari pemilik sekaligus General Manager Halmahera Music School Ibu Sherlly, guru senior Yamaha, Siswa, serta orang tua dari siswa yang mengikuti program Music Wonderland di Halmahera Music School dengan pertanyaan seputar pembelajaran Music Wonderland kepada siswa, menyangkut kesulitan dan kendala selama proses pembelajaran.

Menggunakan teknik wawancara dalam penelitian ini dengan pertimbangan bahwa data yang diperoleh akan lebih meyakinkan peneliti, sehingga hasil penelitian lebih akurat mengarah ke tujuan yang diharapkan. Bentuk wawancara yang dilakukan meliputi: (1) Wawancara kepada General Manager Halmahera Music School Semarang, (2) Wawancara kepada guru senior, (3) Wawancara kepada siswa MW (Music Wonderland) / anak usia dini.

\subsubsection{Studi Dokumen}

Dalam studi dokumen ini, dokumen yang akan menjadi bahan penelitian untuk menunjang peneliti dalam meneliti pembelajaran musik dengan program Music Wonderland ini adalah Teaching Guide (panduan mengajar) yang dimiliki oleh guru.

Data yang dicari berupa berdirinya Halmahera Music School, les yang ada di Halmahera Music School, jumlah guru dengan masing-masing bidangnya, jumlah siswa, alat musik atau barang-barang yang digunakan dalam pembelajaran 
Music Wonderland, materi ajar, kurikulum yang digunakan di Halmahera Music School Semarang.

\subsection{Metode Pemeriksaan Keabsahan Data}

Pemeriksaan keabsahan data dapat dilakukan dengan banyak kriteria keabsahan data kualitatif, akan tetapi peneliti menggunakan derajad kepercayaan dan menggunakan teknik triangulasi. Triangulasi berarti verifikasi penemuan melalui informasi dari berbagai sumber, menggunakan multi-metode dalam pengumpulan data, dan sering juga oleh beberapa peneliti (Sumaryanto, 2007: 114). Triangulasi dapat dilakukan dengan tiga cara, yaitu triangulasi sumber, triangulasi metode, dan triangulasi data. Dengan penjelasan sebagai berikut: (1) Trianggulasi sumber adalah keabsahan data dengan mengacu pada sumber merupakan pengecekan derajad data yang diperoleh berdasarkan fakta di lapangan / obyek penelitian, (2) Triangulasi metode adalah keabsahan data dengan mengacu pada metode merupakan pengecekan derajat kepercayaan penemuan hasil penelitian dengan pengecekan derajat kepercayaan beberapa sumber data dengan metode yang sama. Hal ini dilakukan peneliti karena sumber informan tidak hanya satu orang.Peneliti juga melakukan observasi dan wawancara untuk memperoleh data, jadi tidak terfokus pada satu metode saja, (3) Triangulasi data adalah keabsahan data dengan mengacu pada data merupakan triangulasi dengan menambah atau memperkaya data sampai dirasa cukup. Dalam penelitian ini peneliti sudah melakukan hal tersebut dengan mencari literatur sebanyakbanyaknya untuk memperoleh data yang sesuai dengan permasalahan yang ada selengkap-lengkapnya. 


\subsection{Teknik Analisis Data}

Bogdan dalam Sugiyono (2013: 244) menyatakan bahwa analisis data adalah proses mencari dan menyusun secara sistematis data yang diperoleh dari hasil wawancara, catatan lapangan, dan bahan-bahan lain, sehingga dapat dengan mudah difahami, dan temuannya dapat diinformasikan kepada orang lain. Analisis data dilakukan dengan mengorganisasikan data, menjabarkannya kedalam unitunit, melakukan sintesa, menyusun ke dalam pola, memilih mana yang penting dan akan dipelajari, dan membuat kesimpulan yang dapat diceritakan kepada orang lain, Sugiyono (2013: 244).

Susan Stainback dalam Sugiyono (2013: 244) mengatakan bahwa analisis data merupakan hal yang kritis dalam proses penelitian kualitatif. Analisis digunakan untuk memahami hubungan dan konsep dalam data sehingga dapat dikembangkan dan dievaluasi.

Berdasarkan hal di atas, dapat disimpulkan, bahwa analisis data adalah proses sistemtis dalam mencari dan menyusun data yang diperoleh dari hasil observasi (catatan lapangan), wawancara, dan studi dokumen dengan memilah, menjabarkan, mengelompokkan dan membuat kesimpulan sehingga dapat lebih mudah dipahami untuk selanjutnya dapat dikembangkan dan dapat dievaluasi atau bahkan menjadi teori.

Analisis data dilakukan sejak sebelum memasuki lapangan, selama di lapangan, dan setelah selesai dari lapangan. Walau begitu, dalam penelitian kualitatif analisis data lebih diutamakan ketika peneliti berada di lapangan, 
bersamaan dengan pengumpulan data. Analisis data yang dilakukan sebelum peneliti memasuki lapangan dilakukan terhadap data hasil study lapangan, atau data sekunder. Hal ini dapat dilakukan untuk mendapatkan fokus penelitian sementara. Fokus penelitian sementara dalam penelitian kualitatif dapat berkembang ketika peneliti sudah memasuki lapangan.

Analisis data difokuskan ketika peneliti sudah memasuki lapangan saat pengumpulan data. Seperti saat melakukan wawancara, peneliti sudah menganalisis hasil wawancara. Sehingga, apabila hasil wawancara kurang memuaskan, peneliti dapat melakukan wawancara lagi, sampai dirasa mendapatkan data yang kredibel. Analisis data juga dilakukan secara interaktif dan berlangsung terus menerus sampai tuntas. Menurut Miles dan Huberman dalam Sugiyono (2013: 246) aktivitas dalam analisis data diataranya data reduction, data display, dan conclusion drawing/verivication.

Data reduction disebut juga dengan reduksi data adalah merangkum, memilih hal yang pokok atau penting, membuat kategori dan membuang yang tidak dipakai sehingga mendapatkan tema atau polanya. Dengan demikian, data yang diperoleh akan lebih jelas, sehingga peneliti akan lebih mudah untuk mengumpulkan data selanjutnya dan mencarinya jika diperlukan.

Tujuan utama dari penelitian kualitatif dapat dijadikan panduan utama dalam mereduksi data. Ketika peneliti menemukan segala sesuatu yang dianggap asing dan tidak dikenal, hal ini lah yang akan dijadikan perhatian peneliti dalam mereduksi data. Mereduksi data apat didiskusikan dengan orang yang dianggap 
ahli sehingga pikiran peneliti dapat berkembang dan mendapatkan data yang bernilai tinggi.

Data display atau penyajian data adalah mendisplay atau menyuguhkan data. Penyajian data dapat dilakukan dengan tabel, grafik, pictogram, uraian singkat, atau sejenisnya. Alam penelitian kualitatif yang sering digunakan adalah dengan dengan kalimat-kalimat atau teks naratif. Melalui hal tersebut, data dapat terorganisasikan, tersusun dalam pola atau hubungan, sehingga akan makin mudah dipahami. Dari sini kita akan menemukan data yang baku atau data yang grounded sehingga dapat disajikan pada laporan akhir.

Langkah terakhir dalam analisis data menurut Miles dan Huberman adalah conclusion drawing atau disebut juga dengan verifikasi atau penarikan kesimpulan. Kesimpulan yang dimaksud dalam penelitian kualitatif adalah kesimpulan yang baru dan belum pernah ada sebelumnya yang telah didukung dengan bukti-bukti yang valid dan konsisten sehingga mengahsilkan kesimpulan yang kredibel. 
Berikut adalah skema analisis data kualitatif, Miles dan Huberman dalam Sugiyono (2013: 247).

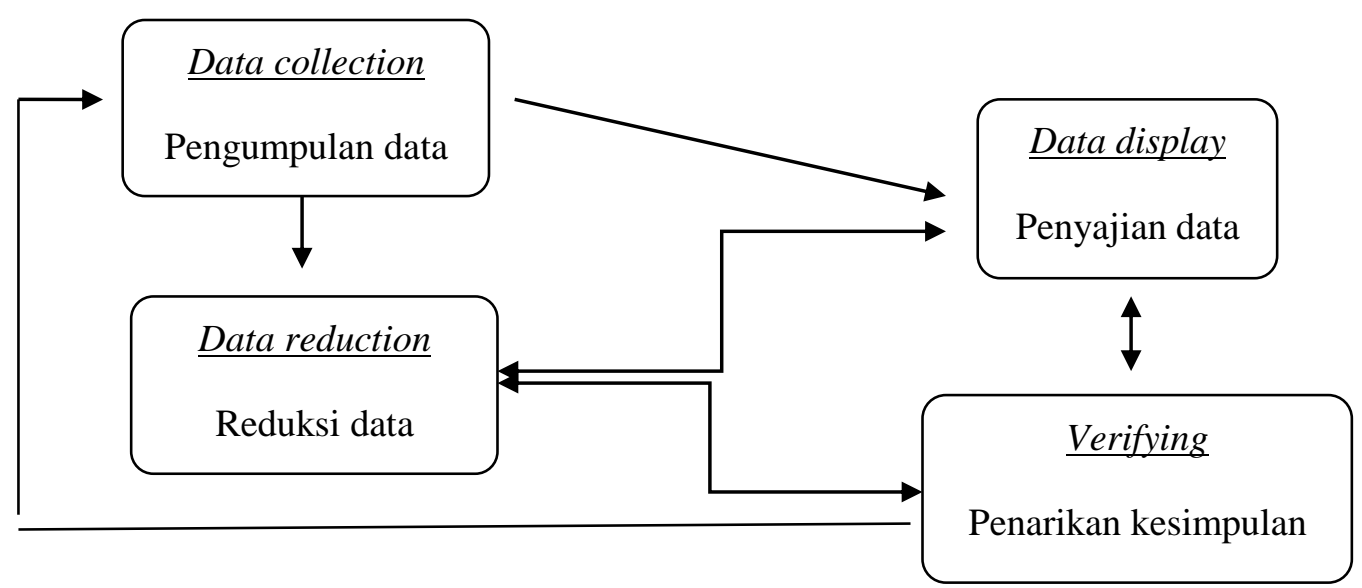

Gambar 3.1. Komponen dalam analisis data model interktif (interactive model)

Sebelum terjun ke lapangan, peneliti hendaknya sudah memiliki data-data yang akan dilakukan untuk menentukan fokus penelitian sementara. Data-data yang ada dikumpulkan terlebih dahulu ditambah dengan data yang ditemukan dari lapangan, tentu menghasilakan data yang banyak, kompleks dan rumit. Untuk itu, maka perlu dicatat atau dirinci kemudian dianalisis melalui reduksi data (merangkum, memilih mana yang penting serta dapat dikembangkan, dan yang tidak). Dari data yang sudah terkumpul, juga dapat langsung disajikan, jika hal itu merupakan temuan baru.

Data yang telah direduksi, dapat disajikan dalam uraian singkat untuk selanjutnya ditarik kesimpulan. 


\section{BAB 4}

\section{HASIL PENELITIAN DAN PEMBAHASAN}

\subsection{Gambaran Umum Lokasi Penelitian}

Gambaran umum lokasi penelitian akan diuraikan hal-hal berikut : (1) Berdirinya Halmahera Music School di Semarang (2) Kondisi fisik, sarana dan prasarana.

\subsubsection{Berdirinya Halmahera Music School Semarang}

Peneliti memperoleh informasi melalui wawancara dengan Sherly, yang menjabat sebagai General Manager Halmahera Music School, berdirinya Halmahera Music School berawal dari keinginan Sherly untuk membuat sebuah sekolah musik di Kota Semarang. Keinginan tersebut datang ketika pulang setelah menjalani sekolah dari Singapura dia tidak ada pekerjaan. Ide tersebut disetujui oleh orang tuanya, yaitu Bapak Tresna Djajakusuma dimana beliau adalah pemilik sebuah tempat penjualan alat musik dan sound system di Semarang yang bernama Halmahera Musik.

Halmahera musik berada di Jalan Maluku Raya 19, Karang Tempel, Semarang Timur. Toko Halmahera Musik, merk Yamaha merupakan salah satu yang tersedia dijual disana. Dengan kerjasama yang baik dan sudah terjalin sejak lama antara Halmahera Musik dan Yamaha Musik, dan bertepatan pasca berhentinya kerjasama antara (YMI) Yamaha Musik Indonesia dengan salah satu sekolah musik ternama di Semarang yaitu Purnomo Music School pada bulan Februari 2012. Pihak YMI (Yamaha Musik Indonesia) menawarkan kerjasama 
kepada pihak Halmahera Musik. Bentuk kerjasama yang ditawarkan oleh (YMI) Yamaha Musik Indonesia adalah untuk membuka sekolah musik dengan lisensi dari (YMI) Yamaha Musik Indonesia, yaitu Yamaha Music School.

Pihak Halmahera Musik belum memberikan respon tawaran dari YMI (Yamaha Musik Indonesia) tersebut, namun dari YMI (Yamaha Musik Indonesia) kembali memberikan, dan kemudian dari pihak Pemilik Halmahera Musik yaitu bapak Tresna Djajakusuma pada akhirnya memutuskan untuk bekerjasama dengan YMI (Yamaha Musik Indonesia) untuk membuka sekolah musik dengan lisensi Yamaha Music School tersebut.

Lisensi Yamaha Music School yang sudah diakui dunia, atau dengan kata lain sudah bertaraf internasional, ini menjadi alasan yang kuat untuk pihak Halmahera Musik mendirikan sekolah musik tersebut. Selain itu, penelitian para ahli yang menyatakan bahwa musik menjadi sangat penting bagi perkembangan otak manusia.

Hasil penelitian Herry Chunagi (1996) Siegel (1999), yang didasarkan atas teori neuron (sel konduktor pada sistem saraf), menjelaskan bahwa neuron akan menjadi sirkuit jika ada rangsangan musik, rangsangan yang berupa gerakan, elusan, suara mengakibatkan neuron yang terpisah bertautan dan mengintegrasikan diri dalam sirkuit otak. Semakin banyak rangsangan musik diberikan akan semakin kompleks jalinan antarneuron itu. Itulah sebenarnya dasar adanya kemampuan matematika, logika, bahasa, musik, dan emosi pada anak. Dengan adanya berbagai penelitian yang mendukung pendapat tadi, ini salah satu 
alasan yang membuat musik semakin diminati banyak orang untuk mempelajari musik.

Keputusan untuk mendirikan sebuah sekolah musik dengan lisensi Yamaha Music School telah diambil, pihak Halmahera Musik yaitu Bapak Tresna Djajakusuma, kemudian mempersiapkan kebutuhan untuk sekolah musik yang akan didirikan. Seperti sewa gedung, recruitment karyawan untuk keperluan perawatan sekolah musik, show room, dan untuk tata usaha. Ada juga berbagai instrumen atau alat musik yang akan dipakai dalam proses kursus musik, sound system, dan perlengkapan lainnya.

Tanggal 1 November 2012 Halmahera Music School resmi dibuka, dan yang membuka dan meresmikan adalah pemilik / direktur utama dari Halmahera Music School Bapak Tresna Djajakusuma bersama beberapa petinggi dari Yamaha Musik Indonesia (YMI) di Jalan Achmad Yani 193 Semarang.

Minat masyarakat untuk belajar musik sangat tinggi sejak Halmahera Music School didirikan. Terbukti, sejak tahun 2012 hingga saat ini, murid di Halmahera Music School terus bertambah. Jumlah murid yang ada di Halmahera Music School diperkirakan mencapai 1200 murid, bahkan lebih. Jumlah murid Halmahera Music School mendapatkan predikat sekolah musik dengan murid terbanyak di Jawa Tengah.

Permintaan yang terus bertambah dari luar, menyebabkan pihak Halmahera Music School membuka cabang sekolah musik di daerah Puri Anjasmoro. Tujuan tersebut untuk lebih mencakup lagi seluruh daerah Semarang, khususnya Semarang Barat, seperti: Mangkang, Ngaliyan, Mijen, hingga Boja. 
Banyak murid yang berasal dari daerah Semarang Barat, arah dari Semarang Barat menuju Halmahera Music School yang beralamat di Jalan Achmad Yani, dapat menempuh perjalanan sejauh lebih dari 10 kilometer, ditambah dengan kondisi jalan yang macet karena volume kendaraan yang terus bertambah. Halmahera Music School di Puri Anjasmoro, memberi kemudahan bagi para murid dalam melakukan perjalanan. Murid yang berasal dari daerah Semarang Barat yang sebelumnya belajar musik di jalan Achmad Yani, diperbolehkan untuk pindah di Halmahera Music School yang ada di Puri Anjasmoro.

Halmahera Music School Puri Anjasmoro diresmikan persis dua tahun setelah Halmahera Music School Achmad Yani didirikan, yaitu 1 November 2014 yang beralamat di Jalan Puri Anjasmoro blok I2 no 1. Letaknya persis di tengahtengah perumahan elit di Semarang.

\subsubsection{Kondisi Fisik}

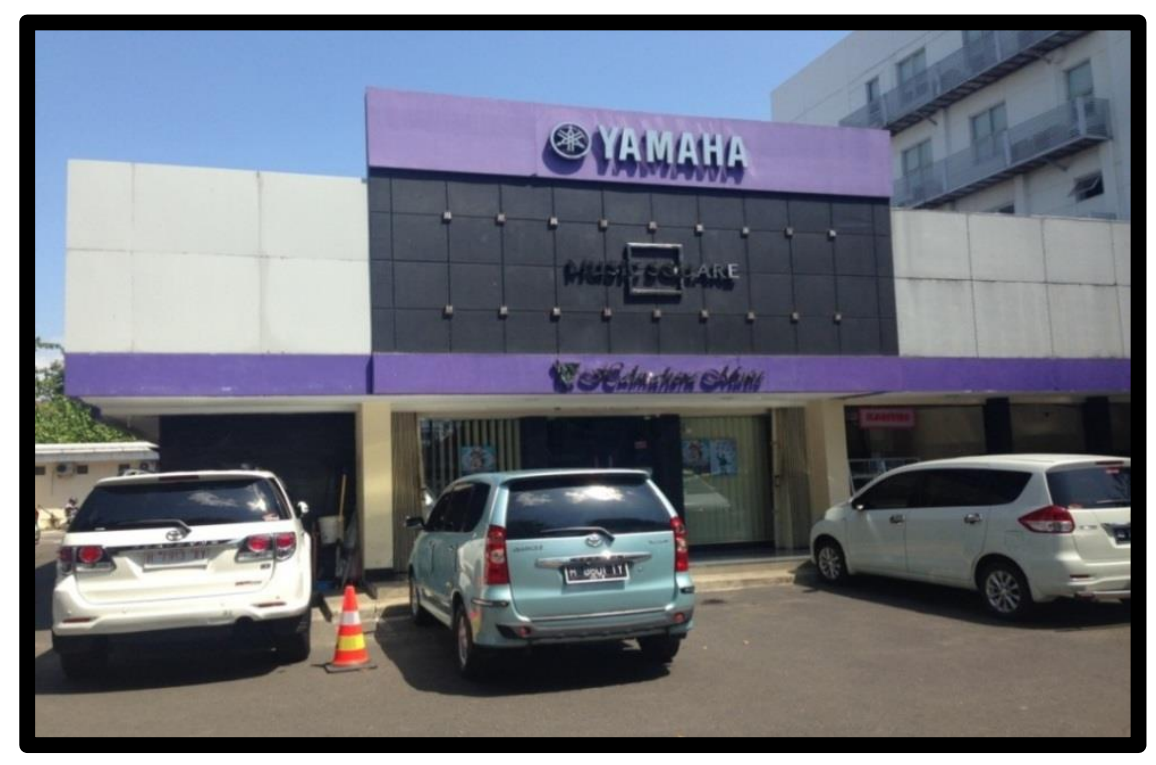

Gambar. 4.1. Foto tampak depan Halmahera Music School Achmad Yani, (Dokumentasi: Didi Hermanto, September 2016) 
Halmahera Music School Achmad Yani berdiri di atas tanah seluas +/- 1500 $\mathrm{m}^{2}$, terletak di Jalan Achmad Yani 193 Semarang, Semarang Timur, Kota Semarang, Propinsi Jawa Tengah, tepatnya di samping Bank Mandiri. Bangunan tersebut menghadap ke utara dengan batas-batas sebelah utara berbatasan dengan Jalan Achmad Yani langsung dan diseberang jalan terdapat Indomaret dan Happy Puppy Karaoke, sebelah timur berbatasan Jalan Atmodirono, sebelah selatan berbatasan dengan rumah penduduk dan sebelah barat berbatasan dengan Bank Mandiri.

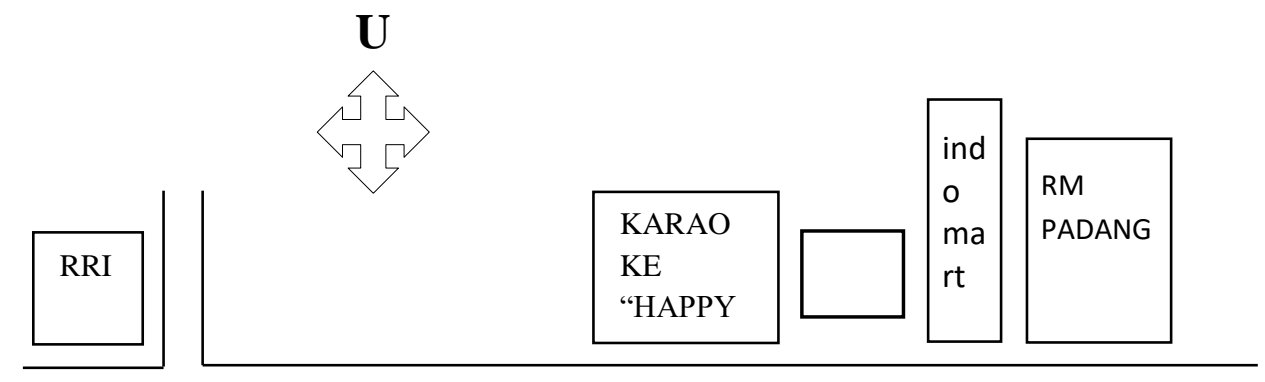

DARI ARAH SIMPANG LIMA

JALAN ACHMAD YANI KE PEDURUNGAN, DEMAK

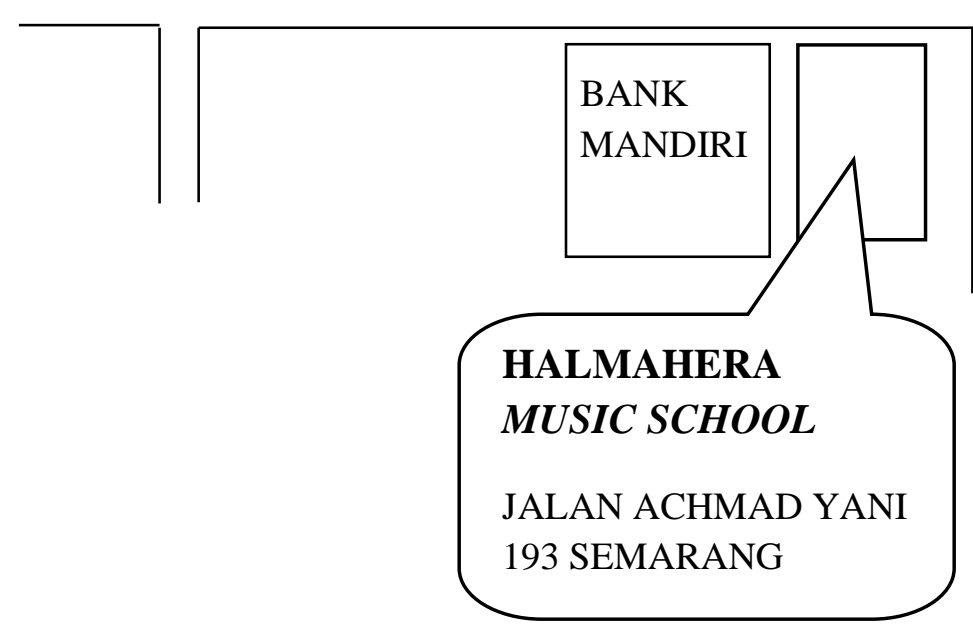

Gambar. 4.2. Lokasi Halmahera Music School Achmad Yani, oleh Didi Hermanto 
Halmahera Music school sangat mudah di cari, karena terletak di tengah kota Semarang, jika dimulai perjalanan dari simpang lima, lihat penunjuk jalan ke arah timur yaitu ke Purwodadi, lurus terus, melewati (RRI) Radio Republik Indonesia Semarang di sebelah kiri jalan, kemudian melewati 1 lampu lalu lintas, dari lampu lalu lintas itu sekitar 100 meter ke arah timur, di sebelah kanan jalan, kita bisa menemukan letak Halmahera Music School tersebut.

\subsubsection{Sarana dan Prasarana}

Halmahera Music School Achmad Yani, terdapat sarana dan prasarana, diantaranya tempat parkir, pos satpam, dan kemudian di dalam gedung sendiri terdapat banyak ruangan, yang terdiri dari 31 ruangan, terbagi menjadi bagian depan, tengah bagian depan, tengah bagian belakang, ruangan bagian belakang, dan lantai dua.

Adapun bagian paling depan adalah ruang Tata Usaha yang menjadi satu denganshowroom, kemudian di bagian depan juga terdapat ruang Owner Halmahera Music School. Kemudian di bagian tengah bagian depan, terdapat 9 ruangan, masing-masing adalah 2 toilet, 1 ruang guru, 3 ruang kelas piano, dan 3 ruang kelas Electone.

Selanjutnya pada ruang tengah bagian belakang terdapat 10 ruangan, masing-masing adalah 1 ruang kelas piano, 1 hall, 2 toilet, 1 ruang kelas biola, 2 ruang kelas keyboard, 2 ruang kelas gitar (akustik dan klasik), dan satu ruangan yang difungsikan sebagai mushola. Kemudian pada bagian belakang terdapat 7 ruangan, terdiri dari ruangan 2 ruang kelas drum, 1 ruang kelas gitar elektrik yang menjadi satu fungsi untuk belajar gitar bass, kemudian 1 ruangan vokal, 1 ruangan 
untuk bagian pengelolaan administrasi Tata Usaha, dan 2 ruang Electone. Ruangan di lantai dua, ada 3 ruangan, yaitu 1 ruang vokal, 1 ruang biola, dan 1 ruang lagi digunakan sebagai gudang.

Setiap depan ruang kelas menjadi ruang tunggu bagi orang tua siswa atau yang mengantar di saat anak sedang mengikuti kelas kursus musik masingmasing. Untuk kenyamanan Halmahera Music School menggunakan AC di semua ruangan, kecuali kamar mandi dan mushola, kemudian untuk melengkapi fasilitas di ruang tunggu, Halmahera Music School menyediakan televisi dan buku bacaan.

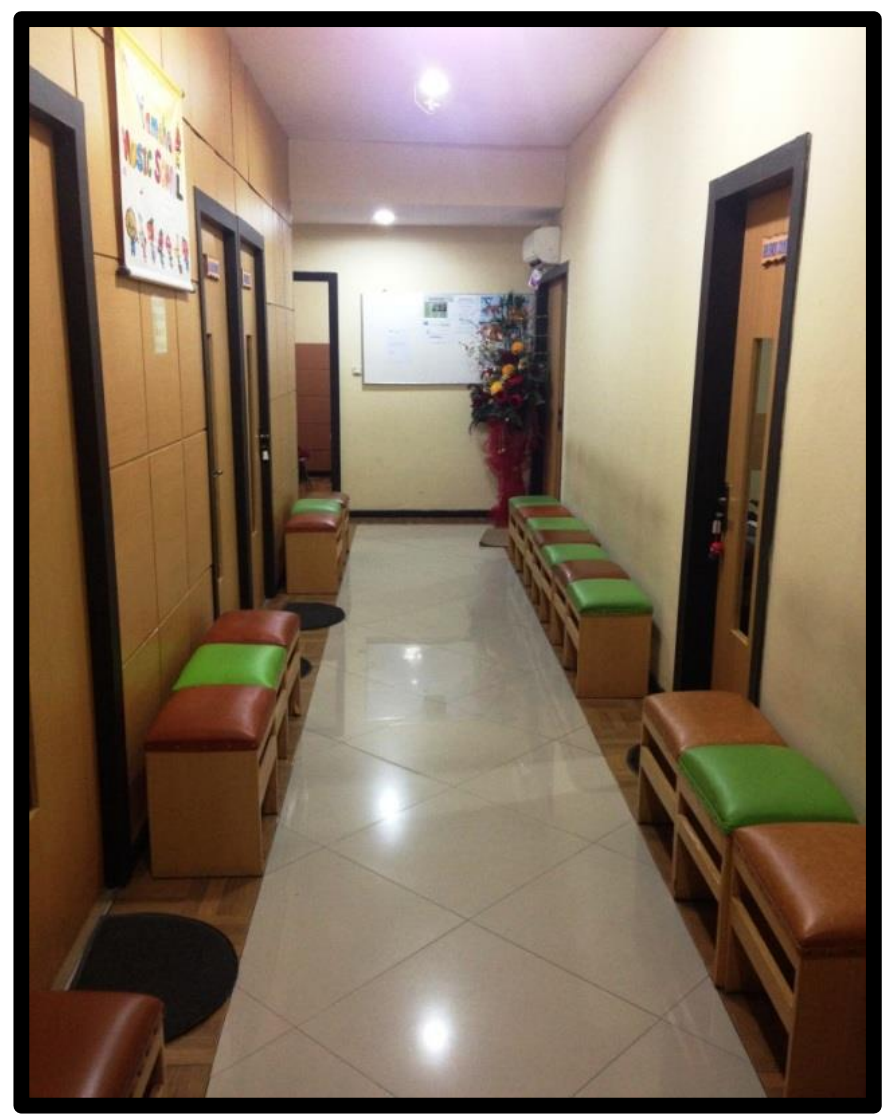

Gambar. 4.3. Ruang tunggu Halmahera Music School Achmad Yani, (Dokumentasi: Didi Hermanto, September 2016) 
Gedung yang sekarang ini diguakan menjadi Halmahera Music School Achmad Yani sebelumnya memang telah ada, kemudian setelah resmi digunakan menjadi Halmahera Music School, gedung ini mengalami beberapa renovasi, seperti penambahan ruangan dan penggantian fungsi ruang dan perombakan ruang. Gedung sekolah ini mampu menampung banyak siswa karena ruang kelasnya cukup banyak yang mencapai 21 ruang kelas dengan berbagai kursus musik.

Halmahera Music School Puri Anjasmoro memiliki ruangan yang lebih banyak. Sebenarnya lokasi tersebut adalah berasal dari dua rumah yang disatukan, sehingga memiliki ruangan yang sangat luas, sekitar $2500 \mathrm{~m}^{2}$. Terhitung, jumlah ruangan yang ada di Halmahera Music School Puri Anjasmoro adalah 43 ruangan. Ruangan sebanyak itu terbagi menjadi dua lantai. Halaman parkir sangat luas, bisa di depan dan dipinggir lokasi, karena lokasi Halmahera Music School Puri Anjasmoro hook, atau dikelilingi dua jalan. Terdapat 1 ruang satpam, dan 1 ruang Genset. Untuk bagian depan di lantai 1, terdapat sebuah ruangan showroom alatalat musik yang terpajang sepanjang dinding ruangan. Kemudian terdapat 1 ruang guru, yang dilengkapi dengan 1 ruang toilet. Disebelahnya, terdapat ruang privasi sekaligus ruang tamu General Manager dilengkapi 1 buah toilet. Bagian depan lantai 2, terdapat 2 ruang keyboard, 1 ruang gitar akustik, 1 ruang ujian, 1 gudang penyimpanan stok alat musik, dan 2 toilet.

Bagian tengah lantai 1, terdapat 4 ruang elekton, 1 kantin, 3 ruang piano akustik, 1 ruang piano elektrik, 2 ruang istirahat penjaga lokasi, serta 3 toilet. Masuk bagian tengah lantai 2, terdapat 1 balkon, yang difungsikan sebagai ruang 
smooking area, 1 ruang penyimpanan perkakas, 1 ruang mushola. Kemudian 3 ruang vokal, 2 ruang biola, 1 ruang saxophone, 1 ruang gitar akustik dan 1 ruang gitar elektrik, dan 1 ruang drum.

Bagian belakang hanya memiliki 1 lantai saja, terdiri dari 1 ruang hall yang sangat luas dengan ukuran sekitar $15 \mathrm{~m}$ x $10 \mathrm{~m}$. 1 ruang administrasi, 1 ruang gitar akustik, 2 ruang penyimpanan kebutuhan alat musik, dan 1 ruangan drum.

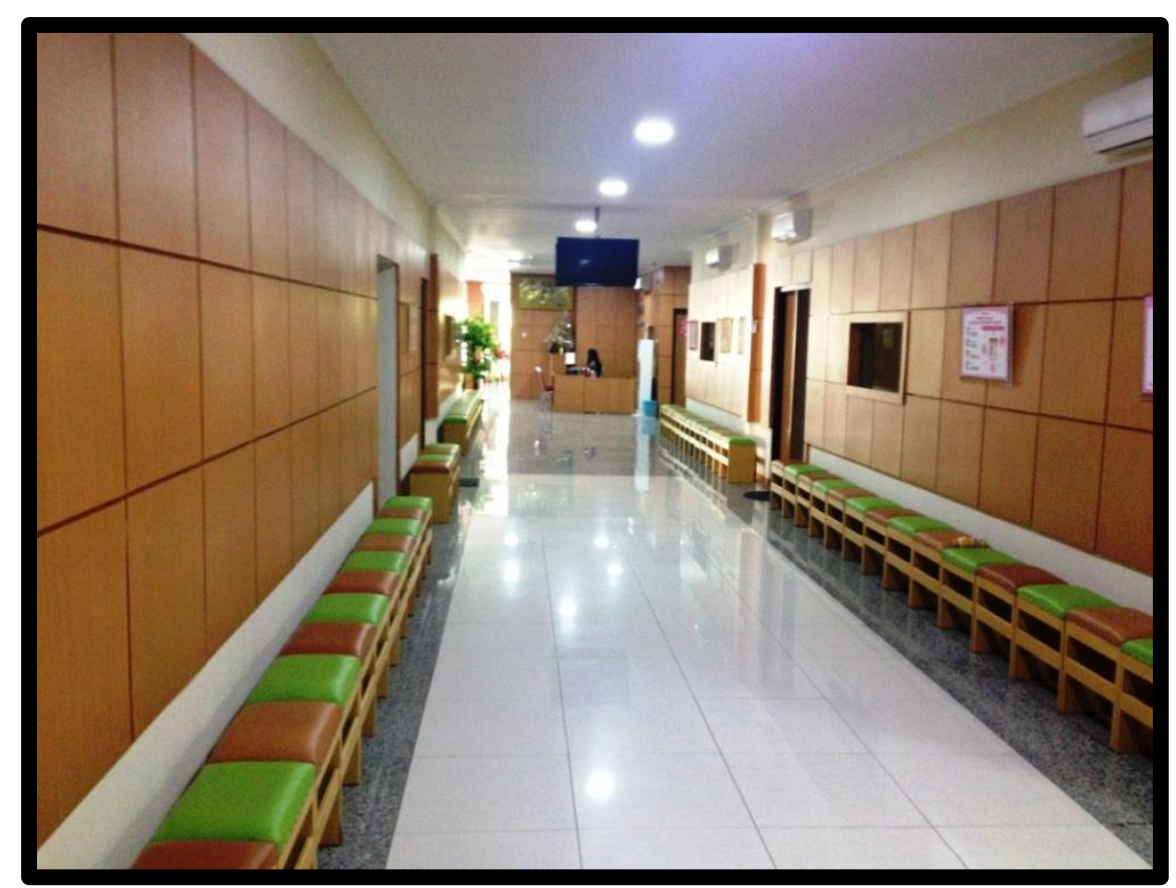

Gambar. 4.4. Ruang tunggu Halmahera Music School Puri Anjasmoro, (Dokumentasi: Didi Hermanto, September 2016)

Halmahera Music School Puri Anjasmoro beralamat di jalan Puri Anjasmoro Blok i2 no 1. Untuk menemukan tidak terlalu sulit, dari Tugu Muda Semarang pergi ke arah Jakarta, belok kanan ke arah PRPP atau Pantai Marina. Akan melewati rel kereta api, terus hingga menemui bundaran. Ketika sampai bundaran, atau tepat di kiri jalan ada tempat hiburan Baby Face, belok kiri. 200 meter 
setelah belok kiri, akan menemui bangunan didominasi berwarna ungu di kanan jalan, itulah Halmahera Music School Puri Anjasmoro.

\subsection{Pembelajaran Music Wonderland di Halmahera Music School Semarang.}

Buku Teaching Guide menjelaskan, poin-poin penting yang harus dicapai dalam pembelajaran Music Wonderland adalah sebagai berikut: (1) Mari Berteman Dengan Musik (2) Mari Bersenang-senang dengan Mendengar (3) Mari Bersenang-senang dengan Keyboard (4) Mari Menyanyi (Menyanyi dengan Lirik) (5) Langkah Irama/Ritme (6) Apresiasi Musik

4.2.1 Tujuan Pembelajaran Music Wonderland di Halmahera Music School Semarang. Di dalam buku Teaching Guide disebutkan tujuan-tujuan pembelajaran Music Wonderland, yaitu:

4.2.1.1 Mengembangkan kemampuan ekspresi musik kepada anak-anak secara alami yang kaya akan imajinasi dan kreatifitas. Hal ini akan menghasilkan dasar pengekspresian musik dengan berbagai cara seperti menyanyi atau bermain keyboard pada waktu mendatang. Bagi anak-anak yang berumur tiga atau empat tahun, memahami bermacam-macam ekspresi dan nuansa musik melalui perasaan mereka adalah hal yang penting. Dalam hal ini, anak-anak akan mendengarkan dua ekspresi dan nuansa yang berbeda sebagai permulaan, yaitu keras dan lembut berupa lagu yang dinyalakan oleh guru. Disini anak-anak berekspresi menggunakan gerakan apa yang mereka rasakan dan pahami. Didalam pelaksanaannya, didukung dengan komposisi musik yang telah didesain untuk 
melatih kemampuan dan konsentrasi dalam mendengarkan musik secara hati-hati. Hal tersebut membuat anak- anak dapat mengikuti tahapan belajar selanjutnya secara positif dengan kegiatan "mendengar".

Siswa mengikuti gerakan yang diarahkan oleh guru. Semakin lembut lagu yang diputar, gerakan anak-anak juga akan semakin lembut dan sebaliknya. Gerakan yang dilakukan antara lain dengan tepukkan. Ketika musik berbunyi keras, guru akan mengajak siswa untuk bertepuk keras. Dalam keadaan ini, suasana didalam kelas terasa meriah. Ketika musik berbunyi lembut, tepukkan akan lembut juga. Pola tepukan yang digunakan tidaklah sulit.

4.2.1.2 Membuat anak-anak menikmati sebagian perannya dalam memainkan musik yang sesungguhnya, dengan memanfaatkan berbagai macam nada-nada yang ada di keyboard. Tujuannya adalah untuk membuat siswa merasakan bermacam-macam ekspresi dan nuansa dari musik secara konkrit. Pengalamanpengalaman ini dapat membantu mereka akrab dengan musik pada tahapan selanjutnya, yaitu JMC (Junior Music Course), dimana sebuah elemen dari "koordinasi nama-nama/ jenis-jenis nada dan keyboard" dikenalkan.

Tetapi, siswa belum diajarkan nama-nama nada yang ada di dalam keyboard, siswa mendengarkan lagu/ musik secara cermat agar mereka bisa mendapat gambaran musik secara jelas sebelum memainkan keyboard. Siswa dilatih menggunakan kedua tangannya. Selama proses ini, siswa dibiarkan memencet keyboard dengan pergerakan tangan yang lebar/ melebarkan jangkauan tangannya, tetapi tetap mengikuti arahan guru di depan. Latihan ini dapat 
membantu memperhalus ekspresi musik mereka melalui pergerakan jari yang bebas. Pada hal ini, guru membiasakan siswa untuk mendengarkan musik dan bunyi yang mereka hasilkan sendiri, karena apa yang mereka bunyikan adalah keinginan (hati) untuk berekspresi semau mereka. Kemampuan (tangan, jari-jari) juga dilatih untuk mengekspresikan perasaannya di keyboard.

4.2.1.3 Mengembangkan dasar ekspresi musik dengan menyanyi, dan meningkatkan sensitivitas. Lagu-lagu yang digunakan adalah lagu buatan Yamaha, sangat sederhana, sehingga sangat mendukung untuk kegiatan pembelajaran. Pada saat musik dimainkan, anak-anak memainkan ritme dengan tangan, dengan jari atau kata-kata (nama nada, menirukan kata-kata, dsb). Mereka bernyanyi menggunakan nama nada dinamakan dengan "Bernyanyi Lirik" (dengan kata Do, Re, Mi).

Guru harus bisa memastikan agar anak-anak menyanyi dengan menggunakan nama nada dengan senang dan antusias. Untuk melakukannya, guru menyiapkan anak-anak agar menyanyi dengan nama nada hanya setelah gambar/bayangan mereka sudah cukup jelas saat menyanyikan lagu dengan katakata. Langkah pertama guru harus memperkenalkan urutan notasi terlebih dahulu, nada dimulai dari Do, Re, Mi, Fa, Sol, La, Si, Do, dan menekankan siswa untuk menghafalnya.

4.2.1.4 Anak-anak mendengar dan memahami irama dalam musik dan mengekspresikannya dengan gerakan seluruh tubuh. Dengan melakukan hal tersebut, rasa dalam hal irama dan ketukan, serta cara mengekspresikan musik 
akan terbangun. Terlebih, membiarkan anak-anak merasa rileks dan segar dengan menggerakkan tubuh bersama orang tua mereka juga merupakan hal yang perlu. 4.2.1.5 Untuk mempertahankan kemampuan dan sikap dalam mendengarkan musik dengan konsentrasi, dan mendapatkan kesan dari musik dengan mendengarkannya. Hal pertama yang harus dilakukan adalah memberikan kesempatan untuk mendengarkan musik dan mendapat kesan darinya. Tujuannya untuk mengembangkan kemampuan untuk menerima segala jenis musik, meskipun baru pertama kali didengar

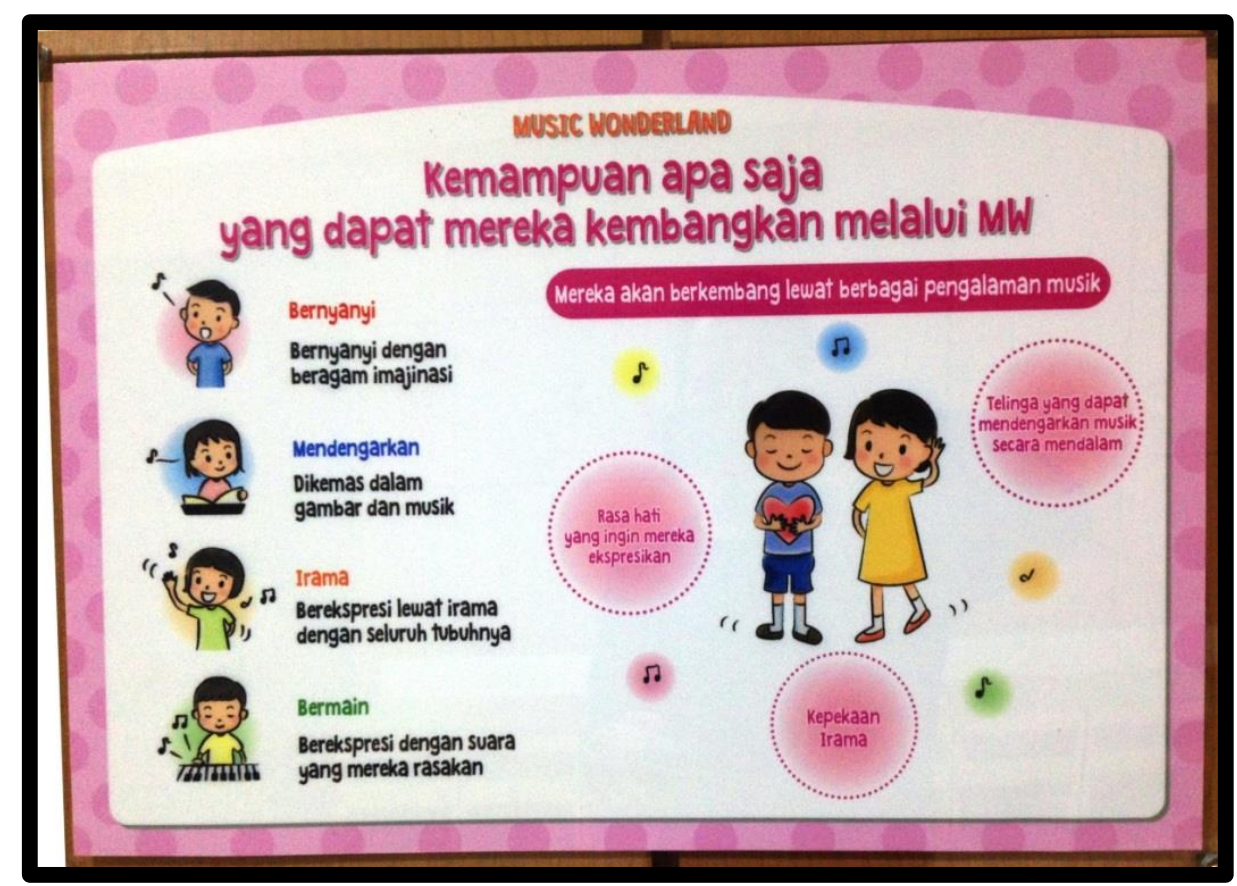

Gambar. 4.5. Foto tentang Music Wonderland,

(Dokumentasi: Didi Hermanto, September 2016)

4.2.2 Langkah kegiatan Pembelajaran Music Wonderland di Halmahera Music

School Semarang.

4.2.2.1 Mengembangkan kemampuan ekspresi musik kepada anak-anak secara alami yang kay a akan imajinasi dan kreatifitas. 
1) Pengajar memotivasi siswa untuk mendengar secara baik-baik dan berkonsentrasi pada musik untuk mengantisipasi birama selanjutnya.

2) Siswa dapat membandingkan dan membedakan dua jenis ekspresi (contohnya $\boldsymbol{f}$ dan $\boldsymbol{p}$, tempo cepat dan lambat, lengkingan tinggi dan rendah, dsb.) Menunjukan gambaran nyata yang mudah dipahami bagi anak-anak juga bisa digunakan sebagai latihan untuk membedakan ekspresi musik (contoh, suarasuara hewan dan fenomena alam). Menggunakan judul dan gambar setiap komposisi musik yang ada dibuku-buku juga merupakan cara efektif.

3) Poin-poin utama dari setiap pelajaran yang diberikan dengan memainkan notnot yang tertulis dilembaran musik secara tepat. Selanjutnya, mengasah telinga juga merupakan hal penting.

4) Membiarkan anak-anak bereaksi dengan tubuh merupakan cara yang efektif. Hal ini ditujukan untuk mengecek apa yang telah mereka dengar dan memberikan kesempatan pada mereka untuk mendengar musik dengan lebih menyenangkan dan menarik.

5) Ada beberapa ilustrasi yang tercetak pada Music Wonderland dan Musical Toybox yang bisa digunakan untuk mengajar. Gunakan hal tersebut dengan baik untuk mengembangkan kesan anak-anak saat mendengarkan musik.

6) Untuk menyampaikan tujuan kepada orang tua dan anak-anak, cobalah pilih kondisi dan pemilihan kata yang tepat untuk berbicara pada anak-anak

Contoh: - Ucapan pujian "Kamu bisa mendengarkan musik dengan baik.”

- "Mari dengar suara selanjutnya. Dengarkan dengan s-a-n-g-a-t baikbaik", dsb. 
4.2.2.2 Memanfaatkan berbagai macam nada-nada yang ada di keyboard.

1) Guru mengenalkan keyboard kepada siswa ketika peraturan mengikuti pelajaran sudah diberikan.

2) Biarkan siswa mendengarkan lagu/ musik secara cermat agar mereka bisa mendapat gambaran musik secara jelas sebelum memainkan keyboard. Gambaran tersebut akan memberi pengaruh yang besar bagi permainan mereka.

3) Siswa dilatih menggunakan kedua tangannya. Selama proses ini, biarkan siswa memencet keyboard dengan pergerakan tangan yang lebar/ melebarkan jangkauan tangannya. Latihan ini membantu memperhalus ekspresi musik mereka memalui pergerakan jari yang bebas.

4) Biarkan anak-anak menikmati kesenangan dalam menghasilkan suara bersama dengan teman-temanya dalam kelompok dan sejuknya kedamaian saat tidak ada suara sama sekali. Cobalah untuk tidak membiarkan suarasuara yang tidak berarti didalam kelas. Cobalah memimpin pada siswa agar mereka dapat melakukan sesuatu tanpa kata-kata dari guru seperti "Jangan lakukan hal itu!" atau "Hentikan!"

5) Dengan kegiatan ini, guru dapat menilai anak-anak dengan mudah melalui penampilan mereka, apakah mereka bisa mengikuti kegiatan yang diinstruksikan atau tidak. 
4.2.2.3 Mengembangkan dasar ekspresi musik dengan menyanyi, dan meningkatkan sensitivitas.

1) Mendorong anak-anak untuk mendengarkan $C D$ secara berulang-ulang pada saat dirumah juga merupakan hal penting. Untuk tujuan tersebut, cara penyampaian materi dari pengajar memainkan peran yang sangat penting agar materinya selalu atraktif dan menyenangkan bagi mereka.

2) Anak-anak sangat suka mengulangi hal yang mereka kuasai. Hal penting bagi guru untuk memperdalam apresiasi musik mereka dengan menyanyi secara berulang-ulang. Pada tahap ini, bernyanyi menggunakan nama nada dinamakan dengan Bernyanyi Lirik (dengan kata Do, Re, Mi). Menyanyikan lagu yang terkenal dengan menggunakan nama nada (Do, Re, Mi) pada akhir pelajaran. dapat membuat anak-anak menjadi lebih akrab dengan nama nada.

3) Pastikan anak-anak menyanyi dengan menggunakan nama nada dengan senang dan antusias. Untuk melakukannya, siapkan anak-anak agar menyanyi dengan nama nada hanya setelah gambar/bayangan mereka sudah cukup jelas saat menyanyikan lagu dengan kata-kata. Dan juga, buatlah para orang tua berpartisipasi dalam bernyanyi dengan menyanyikan bagian/ sesi lagu yang berbeda atau bernyanyi bagian demi bagian, dsb.

4) Amati kondisi anak-anak secara teliti and hindari memberi pelajaran yang terlalu menekankan "Latihan". Berikut adalah dua lagu yang disarankan untuk digunakan sebagai materi menyanyi pada Music Wonderland. 


\section{TWINKLE-TWINKLE LITTLE STAR}

Lagu Tradisional Prancis

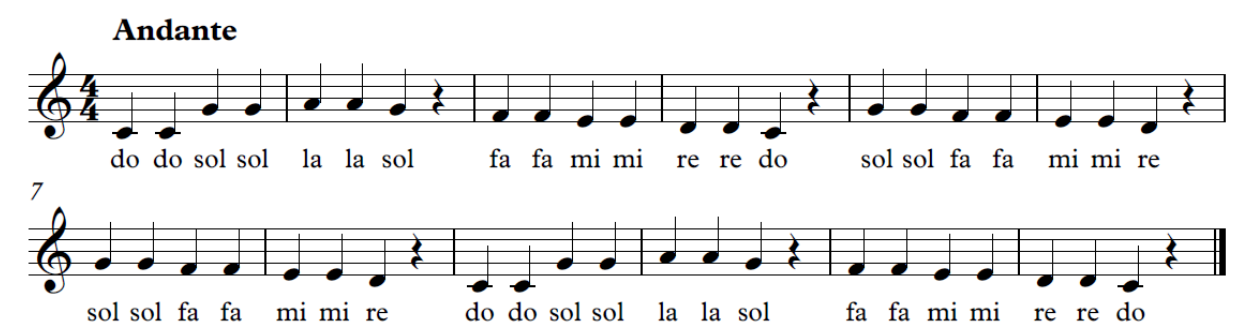

Gambar 4.6. Lagu Twinkle-Twinkle Little Star

(Transkrip oleh Didi Hermanto, Sumber: Teaching Guide)

\section{Frere Jacques (Are You Sleeping)}

Lagu Tradisional Prancis
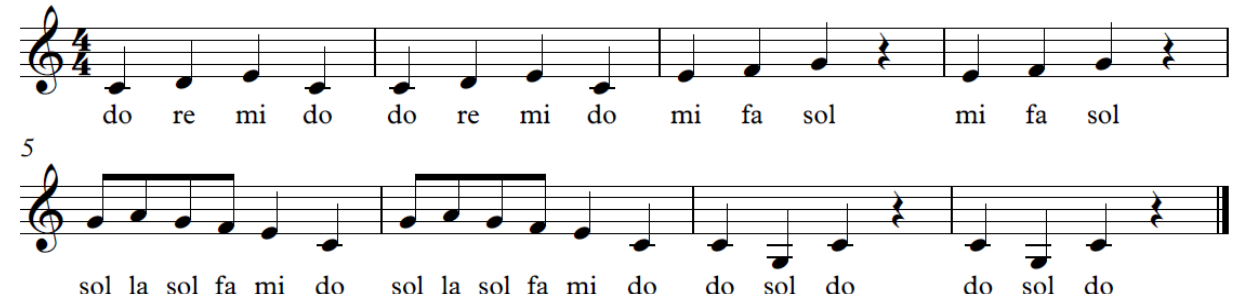

sol la sol fa mi do sol la sol fa mi do do sol do do sol do

Gambar 4.7. Lagu Frere Jacques ( Are You Sleeping )

(Transkrip oleh Didi Hermanto, Sumber: Teaching Guide)

4.2.2.4 Memahami irama dalam musik dan mengekspresikannya dengan gerakan

seluruh tubuh.

1) Pengajar memberikan gerakan yang jelas dan mudah dipahami. Saat mengajar aksen dan ketukan, gerakan persiapan sangat diperlukan. 
Contohnya, mengekspresikan aksen dan ketukan dengan kata-kata dapat membantu anak-anak mengambil nafas sebagai sebuah gerakan persiapan.

2) Membimbing anak-anak dengan mengikuti gerakan dasarnya. Poin penting dari ekspresi ritmik pada tahapan ini ialah untuk membuat anak-anak menikmati apa yang mereka lakukan, jadi mereka akan menguasai rasa dari ritme secara alami dengan mengulanginya lagi dan lagi.

3) Membiarkan anak-anak memanggil kata-kata dari sebuah lagu adalah cara efektif agar mereka bisa merasakan ritmenya dengan jelas dan pahami ekspresi musiknya secara konkrit.

4) Biarkan para orang tua untuk berpartisipasi aktif sesering mungkin.

4.2.2.5 Mempertahankan kemampuan dan sikap dalam mendengarkan musik dengan konsentrasi, dan mendapatkan kesan dari musik dengan mendengarkannya.

1) Apresiasi menggunakan $\mathrm{CD}$, tujuannya juga untuk mengembangkan kemampuan mendengarkan musik dengan imajinasi. Pada tahapan ini, anak-anak didorong untuk mempunyai gambarannya masing-masing dengan menggunakan elemen visual seperti ilustrasi, pergerakan pengajar, dan juga dengan komentar pengajar pada poin tertentu.

2) Apresiasi dengan penampilan pengajar, tujuannya untuk mengembangkan sikap dalam mendengarkan musik melalui penampilan pengajar sementara anak-anak merasakan ekspresi musik, mengutarakan, dan mengambil nafas seperlunya untuk tampil. 
3) Karya musik yang digunakan untuk apresiasi harus bisa dipahami menggunakan perasaan. Hal yang paling penting adalah bagaimana setiap anak merasakan musik dengan hatinya. Dengan rasa tersebut, ekspresi dan reaksi dari anak-anak harus diamati dengan cermat dan direspon dengan sesuai dengan apa yang mereka ekspresikan.

4) Anak-anak menggerakkan tubuhnya secara alami atau bersenandung melodi pada saat mereka mendengarkan musik. Jangan coba mengurangi sikap alami dan kesukarelaan tersebut.

5) Poin-poin apresiasi, elemen-elemen dan materi untuk didengarkan dan dinilai anak-anak adalah sebagai berikut: tempo, ritme, melodi, fase, warna nada (instrumen berbeda, teknik bermain), dinamika, artikulasi, dsb.

6) Pengajaran dilakukan dengan situasi yang hangat yang dibuat oleh anakanak, pengajar, dan orang tuanya.

7) Anak-anak tidak harus mendengarkan musik dari awal. Guru memberikan pelajaran dengan tujuan yang jelas dengan cara penilaian kondisi anakanak secara fleksibel.

\subsubsection{Guru Music Wonderland di Halmahera Music School Semarang.}

Pelaksanaan program Music Wonderland tidak dapat berjalan ketika tidak adanya pengajar. Dalam perekrutan tenaga pengajar, pihak Yamaha benar-benar memilih pengajar secara teliti dan ketat, karena ketika memilih pengajar secara sembarangan, akan berimbas buruk terhadap nama Yamaha itu sendiri. Pengajar program Music Wonderland yang ada di Halmahera Music School Semarang 
berjumlah tiga orang, yaitu Murtini Hartawidjaja, S.H., Niken Wulanwiranti, S.Psi., dr Hendro P Setyo, S.Ked, Sp.PK.

Murtini Hartawijaya lahir di Semarang, 19 Maret 1963. Beliau mengambil kuliah jurusan Hukum di Universitas Kristen Satya Wacana Salatiga pada tahun 1986. Keahlian di bidang musik beliau dapatkan ketika belajar di Purnomo Musik Semarang Lisensi Yamaha sejak SMP. Electone adalah instrumen yang beliau tekuni.

Selama belajar di Purnomo Musik, tidak ada kendala berarti hingga selesai. Murtini Hartawijaya (53 tahun) saat ini memiliki sertifikat Grade 5 Electone Yamaha. Di tahun 1987, Murtini Hartawijaya menjadi guru electone di Purnomo Musik Lisensi Yamaha. Ketika Lisensi Yamaha berpindah ke Halmahera Music School Semarang pada tahun 2014, beliau turut pindah ke Halmahera Music School.

Niken Wulanwiranti, S.Psi., menyelesaikan studi S1 di sebuah perguruan tinggi di Semarang, yaitu Universitas Katholik Soegijapranata pada tahun 1998, mengambil jurusan Psikologi. Beliau lahir di Magelang, 21 Februari 1972. Keahlian musik beliau dapat melalui kursus privat oleh Midya Wirawan, Henk van Dijk, dan Djazeed Djamin. Niken memiliki sertifikat Grade 8 Royal Music Piano, dan Grade 5 Yamaha Piano. Beliau mulai mengajar di Halmahera Music School sejak tahun 2014. Beliau tidak hanya mengajar Music Wonderland, tetapi juga mengajar instrumen piano klasik. 
dr.Hendro Pratomo Setyo, S.Ked, Sp.PK. adalah seorang dokter Patologi Klinik di RSUP Karyadi Semarang. Menyelesaikan studi Kedokterannya di Fakultas Kedokteran Universitas Gadjah Mada Yogyakarta dan lulus pada tahun 1995. Kemudian mengambil Profesi Dokter di kampus yang sama dan lulus tahun 1997. Universitas Diponegoro Semarang, beliau mengambil PPDS1 Patologi Klinik di Fakultas Kedokteran dan lulus tahun 2015.

Purwokerto adalah tempat kelahiran dr.Hendro, yang dilahirkan pada tanggal 3 Mei 1971. Keahlian musik beliau mengambil kursus di Sekolah Musik Purnomo Semarang Sublisensi Yamaha pada tahun 1976-1978. Instrumen yang diambil adalah electone yang saat itu diampu oleh Laura. Selanjutnya di tahun 1984 -1980, dr.Hendro melanjutkan kursus electone di Sekolah Musik Cinintya Purwokerto Sublisensi Yamaha, yang saat itu diampu oleh Fendi.

Selain electone, beliau juga mendalami piano yang diampu langsung oleh Ibu Joni yang saat itu berada di Yayasan Musik Semarang di tahun 1990-1992, dan dilanjut lagi di tahun 1998-2008 dengan guru yang sama. Pada tahun 19951996 juga mengikuti kursus di Pusat Musik Liturgi Yogyakarta dengan alat musik organ, yang diampu oleh Sr. Milburga, Karl Edmund Prier SJ.

Workshop Orgel (Organ Pipa) oleh Reinhold Wagner juga pernah diikuti, dengan materi sebagai berikut: 1. Musik dari zaman Baroque hingga zaman Kontemporer, 2. Improvisasi pada musik gereja. Begitu juga dengan Masterclass piano oleh Teguh Sukaryo. Workshop relaksasi pada permainan piano oleh Sufiah 
Santoso juga pernah beliau ikuti. Tahun 2001 hingga sekarang, menjadi guru electone, dan piano.

Peneliti dalam hal ini, meneliti kelompok belajar yang diampu oleh Murtini Hartawijaya (53 tahun). Sebagai guru pengampu kursus kelas Music Wonderland yang bertepatan sebagai pengampu kelas Music Wonderland pukul 17.00-18.00 yang menjadi sampel penelitian, menjelaskan bahwa di dalam kelas Music Wonderland, sudah ada ketetapan khusus dari Yamaha mengenai batasan umurnya yaitu anatara umur 3-4 tahun.

Begitu juga yang dijelaskan dalam Teaching Guide, atau merupakan buku panduan mengajar untuk guru Music Wonderland, menjelaskan hal yang sama mengenai ketentuan tersebut. Mengingat spesifikasi yang sudah ditetapkan untuk peserta kursus Music Wonderland yang harus dalam batas usia empat sampai lima tahun, maka guru pun telah disiapkan oleh pihak Yamaha untuk mengimplementasikan metode pembelajaran yang sesuai dengan siswa usia antara 3 sampai 4 tahun.

Murtini Hartawidjaja (53 tahun) juga menambahkan, bahwa sebelum mengajar guru dipersiapkan sebaik mungkin oleh pihak Yamaha dengan diberi seminar satu sampai bahkan tiga kali bahkan lebih, dilatih cara mengajar yang baik sesuai dengan kurikulum Yamaha, itu semua yang menjadikan guru Yamaha sudah siap mengajar ketika terjun langsung menjadi guru Music Wonderland secara profesional. Bahkan tidak hanya kursus musik Music Wonderland saja yang guru-gurunya di persiapkan dengan di adakannya seminar, namun semuanya 
jenis kursus musik yang ada di Yamaha, karena sebelum guru mengajar secara profesional, guru-guru Yamaha benar-benar dipersiapkan sebaik mungkin sampai akhirnya siap untuk mengajar secara professional, yaitu dengan mengikuti seminar tersebut.

Syarat untuk bisa menjadi guru Music Wonderland di Yamaha pada khususnya, harus memiliki sertifikat standar grade 5 Yamaha untuk instrumen piano ataupun electone, dan pastinya harus melalui proses audisi yang ketat yang diawasi langsung oleh perwakilan langsung dari Jepang untuk Indonesia. Dalam mengajar Music Wonderland menurut Murtini Hartawidjaja (53 tahun), harus sabar, cinta terhadap anak-anak, karena dalam prosesnya akan menemui hal-hal yang bisa menguji kesabaran, seperti: anak susah diatur, anak tidak bisa menerima pelajaran dengan baik, orang tua memarahi anaknya yang tidak bisa, dan lain-lain. Adapun faktor yang menghambat perkembangan anak yaitu, orang tua yang kurang mendukung, didalam kelas tidak aktif, anak dirumah selalu bermain gadget. Tetapi, Murtini Hartawidjaja (53 tahun) selaku guru Music Wonderland merasa senang ketika melihat perkembangan anak, dari yang tidak bisa fokus jadi fokus, konsentrasi meningkat, dan bisa mengikuti pola irama yang diberikan.

\subsubsection{Media Pembelajaran Music Wonderland di Halmahera Music School} Semarang.

Pembelajaran Music Wonderland di Halmahera Music School dilaksanakan di kelas "Angry Bird". Murtini Hartawidjaja selaku guru Music Wonderland melakasnakan proses pembelajaran dari awal sampai akhir. Di dalam ruangan yang berukuran kurang lebih $7 \mathrm{~m}$ x $5 \mathrm{~m}$ tersebut, terdapat 13 electone dan sebuah 
piano akustik yang digunakan anak-anak untuk pembelajaran Music Wonderland. Alat musik itulah yang digunakan siswa sebagai media untuk mendukung jalannya program Music Wonderland. Di belakang electone terdapat dua kursi yang digunakan oleh anak dengan orang tuanya.

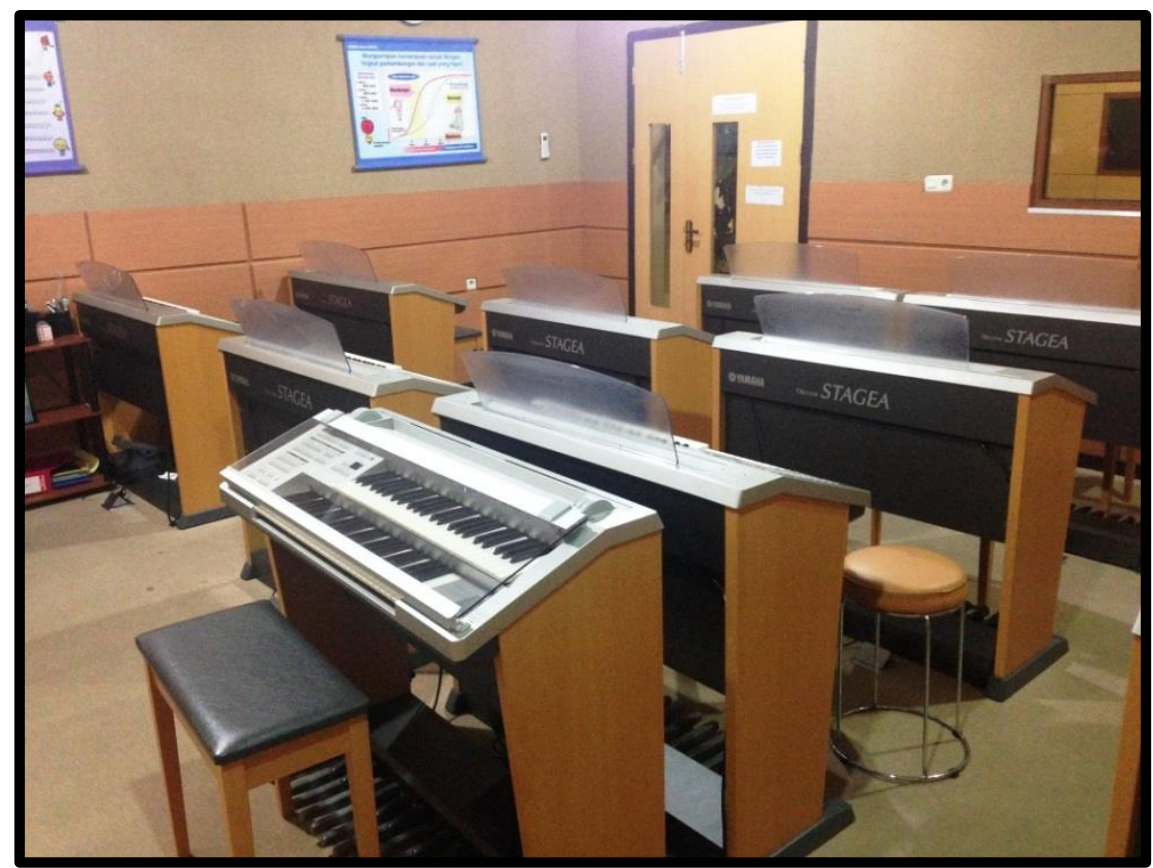

Gambar 4.8. Ruangan belajar Music Wonderland

(Dokumentasi: Didi Hermanto, September 2016)

Pembelajaran Music Wonderland juga menggunakan buku bergambar yang juga disebut Picture-card show. Buku tersebut sebagai media mengkomunikasikan musik. Tujuannya untuk memelihara kemampuan mendengarkan musik secara aktif sementara anak-anak memiliki gambaran jelas dengan kombinasi dari musik, cerita, dan ilustrasi. Misalkan dalam hal ini guru memainkan salah satu musik melalui CD Player dengan judul lagu "Bunyi Drum", seperti yang ada di dalam gambar dibawah ini. Ketika guru memainkan lagu tersebut, siswa harus mencari gambar yang sesuai dengan lagu dibawah ini. 


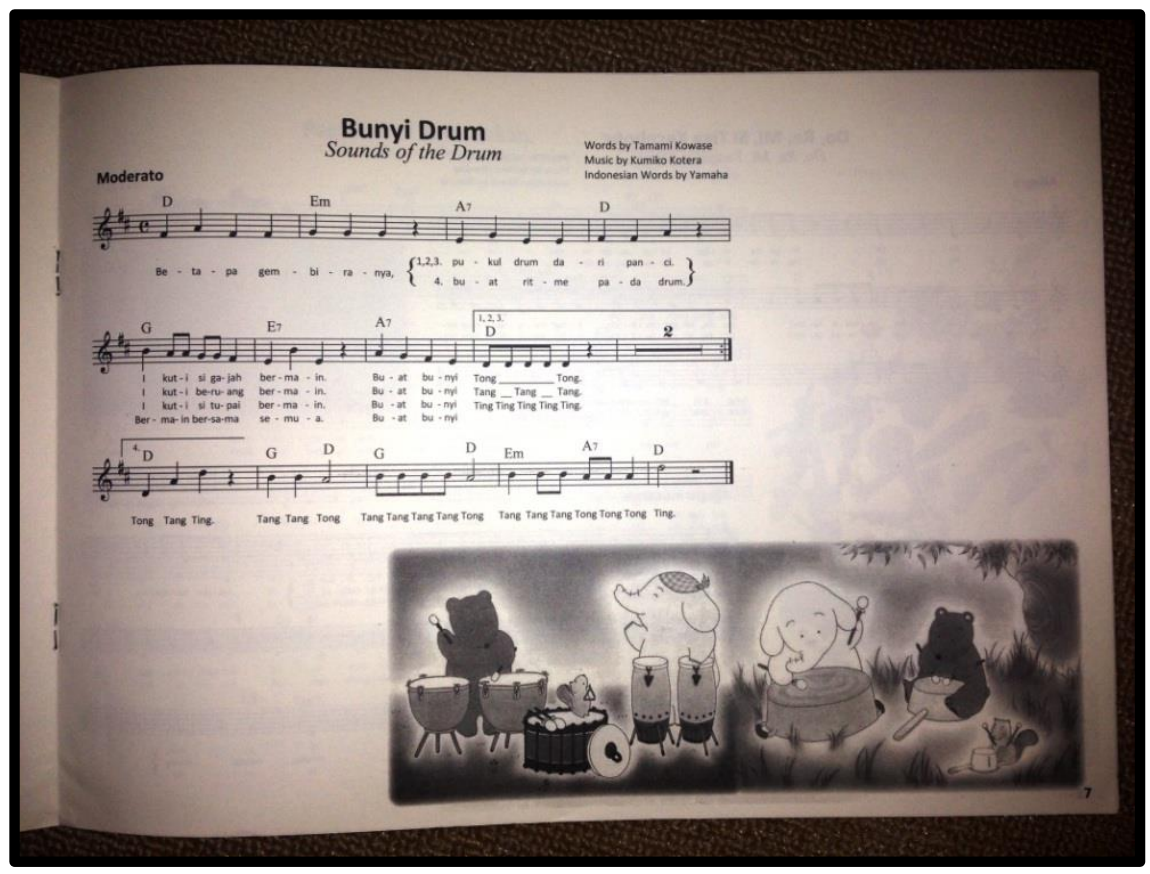

Gambar 4.9. Partitur lagu "Bunyi Drum"

(Dokumentasi: Didi Hermanto, September 2016) (buku pegangan guru)

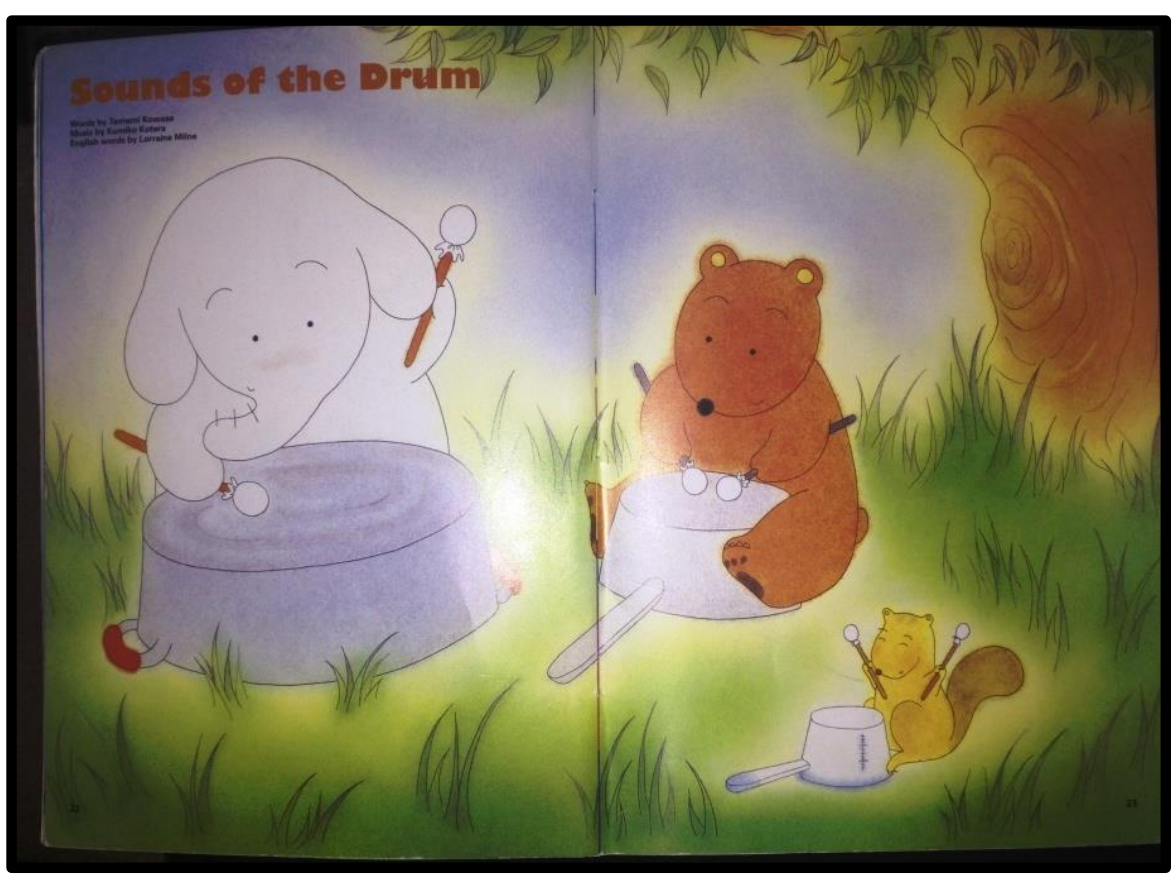

Gambar 4.10. Halaman yang harus dibuka siswa ketika lagu "Bunyi Drum dimainkan guru.

(buku pegangan siswa)

(Dokumentasi: Didi Hermanto, September 2016) 
Ketika anak telah menemukan gambar yang diinginkan, guru selanjutnya mengajari gerakan kepada anak. Khusus lagu ini, gerakan yang digunakan adalah gerakan seperti gerakan tangan seseorang memukul drum. Tangan kanan dan kiri saling bergantian mengikuti tempo lagu "Bunyi Drum". Kemudian guru mengarahkan siswa untuk memukul pada gambar

\subsubsection{Metode Pembelajaran Music Wonderland di Halmahera Music School} Semarang.

Metode yang digunakan pembelajaran Music Wonderland adalah metode ceramah. Metode ceramah adalah penuturan bahan pelajaran secara lisan. Metode ini tidak senantiasa jelek bila penggunaannya betul-betul disiapkan dengan baik, didukung dengan alat dan media, serta memperhatikan batas-batas kemungkinan penggunaannya. Menurut Ibrahim, (2003: 106) metode ceramah adalah suatu cara mengajar yang digunakan untuk menyampaikan keterangan atau informasi atau uraian tentang suatu pokok persoalan serta masalah secara lisan.

Di dalam kelas, guru sebelum masuk ke pelajaran utamanya, pasti akan memberikan ceramah, atau tata cara apa yang harus dilakukan oleh anak-anak. Tetapi dalam prakteknya, guru tidak melakukan metode ini lama, karena dapat dipastikan anak-anak akan merasa bosan, dan ingin tahu apa yang akan dilakukan selajutnya.

Kelebihan metode ceramah adalah guru lebih menguasai kelas, mudah mengorganisasikan tempat duduk/kelas,dapat diikuti oleh jumlah siswa yang besar,mudah mempersiapkan dan melaksanakannya, guru mudah menerangkan

pelajaran dengan baik. Tetapi, kelemahan dari metode ceramah yaitu 
membosankan bila selalu digunakan dan terlalu lama, sulit untuk mengetahui apakah siswa sudah mengerti apa yang telah dijelaskan atau belum, dan menyebabkan siswa menjadi pasif (Djamarah \& Zain, 2010)

Pembelajaran Music Wonderland, sebenarnya lebih banyak menggunakan metode demonstrasi. Pada prosesnya, guru mendemonstrasikan gerakan-gerakan untuk diajarkan pada siswa. Siswa akan mengikuti apa yang dilakukan guru. Metode ini sangat cocok karena siswa tidak akan merasa bosan, dan memang sesuai apa yang diinginkan Yamaha untuk proses Pembelajaran Music Wonderland. Dalam menggunakan metode ini, guru dituntut untuk sabar, karena dalam prakteknya tidak semua siswa langsung memahami. Disinilah peran orang tua sangat penting dalam proses pembelajaran Music Wonderland. Ketika mengarahkan anaknya, orang tua juga harus sabar, terkadang ada orang tua yang memarahi anaknya karena tidak bisa mengikuti gerakan yang diajarkan oleh guru.

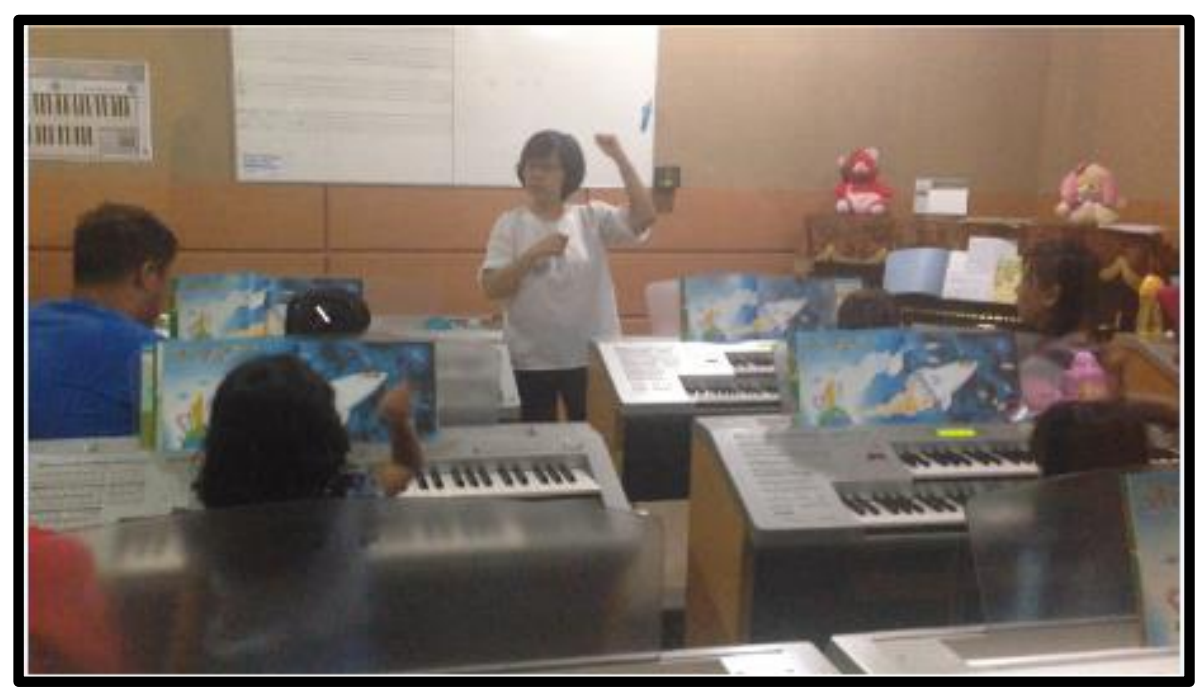

Gambar 4.11. Guru sedang mendemonstrasikan gerakan untuk siswa (Dokumentasi: Didi Hermanto, September 2016) 
Metode drill/latihan juga digunakan dalam proses pembelajaran Music Wonderland. Tetapi tidak sedominan dengan metode-metode diatas, karena hanya sebatas anak untuk mengahafalkan lagu-lagu yang akan diajarkan didalam kelas. Dalam hal ini, orang tua sangat berperan penting dalam dukungannya, agar anakanak dirumah dibimbing untuk menghafalkan lagu-lagu yang diberikan oleh guru pengampu.

4.2.6 Evaluasi Pembelajaran Music Wonderland di Halmahera Music School Semarang.

Evaluasi dari Pembelajaran Music Wonderland di Halmahera Music School Semarang setelah diterangkan berbagai hal mengenai pelaksanaan pembelajarannya, semua berjalan sesuai dengan kurikulum Yamaha yang telah ditentukan. Mengenai hasil pembelajarannya, siswa terbukti senang dan mampu mengikuti proses Pembelajaran Music Wonderland. Didukung dengan hasil ujian yang dilaksanakan pada hari Minggu, 6 November 2016 yang dilaksanakan di Halmahera Music School Puri, karena memiliki kapasitas ruangan yang sangat luas, serta terdapat panggung permanen yang memang didesain untuk tempat diadakan konser.

Jadwal ujian yang dilaksanakan pukul 10.00 hingga pukul 12.00 dihadiri oleh banyak penonton, termasuk para orang tua yang mendampingi anak-anaknya. Untuk hal ini, peneliti tidak diizinkan untuk mengabadikan proses ujian, karena dapat mengganggu konsentrasi anak. Tepat pukul 10.00, ujian Music Wonderland dilaksanakan. Jumlah siswa yang mengikuti ujian kali ini berjumlah 18 anak, 
jumlah tersebut adalah jumlah murid dari tiga guru, yaitu Murtini Hartawidadjaja, Hendro Pratomo Setyo, dan Niken Wulanwiranti.

Proses evaluasi dari pembelajaran Music Wonderland yaitu dengan dilakukan ujian untuk mengukur kemampuan siswa. Bentuk ujian dari pembelajaran Music Wonderland adalah siswa diuji diatas panggung atau bisa disebut sebagai konser. Siswa dituntut untuk berani tampil diatas panggung. Tetapi, dalam ujian pembelajaran Music Wonderland,siswa tidak ada tuntutan untuk bisa bermain scale (tangga nada), membaca not balok seketika (sight reading), dan sebagainya, karena memang dalam pembelajaran Music Wonderland, tidak diajarkan hal-hal yang disebutkan diatas. Intinya, pembelajaran Music Wonderland itu hanya untuk bersenang-senang, tetapi mempunyai tujuan tersirat untuk membentuk konsentrasi anak, kepekaan dalam mengikuti tempo, meningkatkan memori siswa.

Siswa maju bersama-sama dengan siswa yang lain untuk menunjukkan apa saja yang pernah mereka peroleh didalam pembelajaran Music Wonderland. Gerakan yang mereka lakukan diatas panggung adalah gerakan yang mereka lakukan didalam kelas. Jadi, tujuan konser ini adalah mengukur sampai mana kemampuan siswa dalam menerima materi. Diatas panggung, kemampuan siswa akan terlihat, siswa mana saja yang mengalami perkembangan setelah mengikuti kegiatan pembelajaran Music Wonderland ini selama satu tahun. Disisi lain, tujuan konser ini adalah untuk menunjukan kepada orang tua siswa, sejauh manakah kemampuan anak-anak mereka, karena dalam konser ini siswa-siswa ditonton langsung oleh orang tua mereka. 
Setelah konser berlangsung, semua siswa dipanggil ke atas panggung, pda saat itu juga sertifikat dibagikan, menandakan pembelajaran Music Wonderland telah usai. Ketika pembelajaran telah usai, setiap siswa diberi kesempatan untuk melanjutkan ke jenjang berikutnya, yaitu Junior Music Course (JMC), ataupun memutuskan untuk tidak melanjutkan lagi.

Mengenai hasil pembelajarannya, siswa yang bisa dikatakan berhasil adalah siswa yang dahulu tidak fokus, mereka bisa fokus, konsentrasi meningkat, memori meningkat, karena dilatih dengan cara diuji kemampuan daya ingat anak dengan menggunakan musik dan gambar. Hasil yang sangat membanggakan ada mereka bisa merasakan tempo, karena diumur 3-4 tahun sangatlah susah untuk mengikuti tempo.

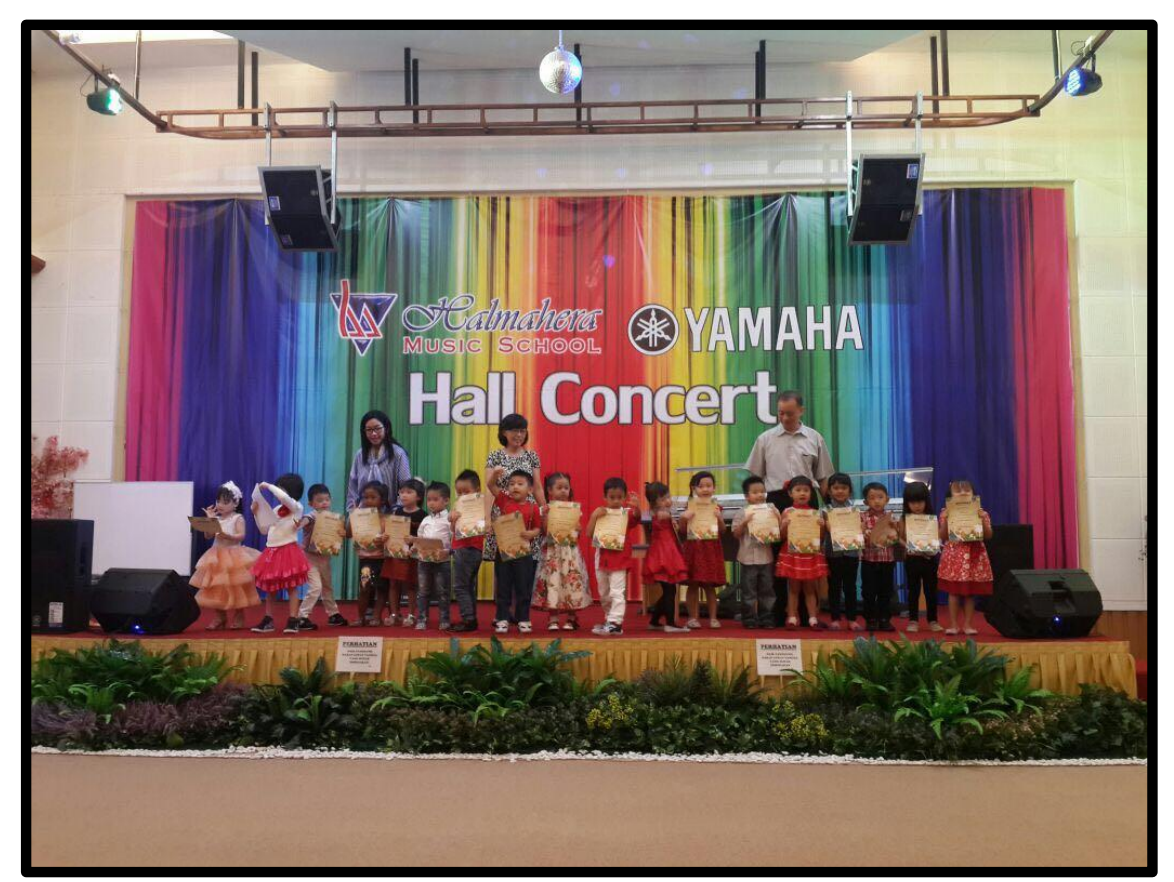

Gambar 4.12. Suasana setelah konser, dan pembagian sertifikat, dan didampingi oleh guru masing-masing.

(Dokumentasi: Didi Hermanto, September 2016) 


\section{BAB 5}

\section{PENUTUP}

\subsection{Simpulan}

Hasil penelitian dan pembahasan tentang Pembelajaran Musik dengan Program Music Wonderland di Halmahera Music School Semarang, maka dapat disimpulkan bahwa:

Pembelajaran Musik dengan Program Music Wonderland, guru mempersiapkan beberapa poin penting yang semuanya dijelaskan di dalam buku panduan mengajar (Teaching Guide) dan ini yang harus menjadi acuan guru dalam mengajar, sebagai berikut : (1) Tujuan-Tujuan Pengajaran, (2) PrinsipPrinsip Pendidikan Music Wonderland, (3) Karakter Perkembangan Anak-Anak usia 3-4 tahun, (4) Tingkat Pencapaian Kemampuan Selama Pembelajaran, (5) Pokok-Pokok Pengajaran dan Tujuannya, dan (6) Buku Teks / Rencana Kurikulum.

Sebelum memulai pelajaran, guru terlebih dahulu mengulas pelajaran pada pertemuan sebelumnya, kemudian memberikan suatu kegiatan-kegiatan agar siswa aktif dan bersiap untuk menerima materi selanjutnya. Selanjutnya dalam pelaksanaan pembelajaran Music Wonderland, terdapat enam poin yang harus dicapai, yaitu: (1) Mari Berteman Dengan Musik (2) Mari Bersenang-senang dengan Mendengar (3) Mari Bersenang-senang dengan Keyboard (4) Mari Menyanyi (Menyanyi dengan Lirik) (5) Langkah Irama/Ritme (6) Apresiasi Musik 
Evaluasi dari pembelajaran Music Wonderland yaitu dengan dilakukan ujian untuk mengukur kemampuan siswa. Pada proses ujian, kemampuan siswa diuji diatas panggung atau bisa disebut sebagai konser. Siswa dituntut untuk berani tampil diatas panggung. Pada prosesnya, siswa maju bersama-sama dengan siswa yang lain untuk menunjukkan apa saja yang pernah mereka peroleh didalam pembelajaran Music Wonderland. Gerakan yang mereka lakukan diatas panggung adalah gerakan yang mereka lakukan didalam kelas. Pada saat itu juga sertifikat dibagikan ketika ujian telah selesai, menandakan pembelajaran Music Wonderland telah usai. Ketika pembelajaran telah usai, setiap siswa diberi kesempatan untuk melanjutkan ke jenjang berikutnya, yaitu Junior Music Course $(J M C)$, ataupun memutuskan untuk tidak melanjutkan lagi. (Suharto and Indriyanto 2018).

Mengenai hasil pembelajarannya, siswa yang bisa dikatakan berhasil adalah siswa yang dahulu tidak fokus, mereka bisa fokus, konsentrasi meningkat, memori meningkat, karena dilatih dengan cara diuji kemampuan daya ingat anak dengan menggunakan musik dan gambar. Hasil yang sangat membanggakan ada mereka bisa merasakan tempo, karena diumur 3-4 tahun sangatlah susah untuk mengikuti tempo.

Dengan demikian, bila pembelajaran Music Wonderland dilaksanakan sesuai dengan landasan teori yang dipakai, terbukti efektif dalam perkembangan anak yang ditujukan untuk anak usia 3-4 tahun, dimana masa-masa tersebut adalah masa perkembangan fisik/kinetik, intelektual, emosi, dan perkembangan tingkah laku yang sangat baik,sehingga sangat efektif pula dalam membentuk dan 
menumbuhkan kepekaan musikal dan skill siswa. Siswa dilatih dari dasar secara musikal agar mampu menghasilkan kualitas musik yang baik.

\subsection{Saran}

5.2.1 Untuk setiap lembaga pendidikan non formal / kursus musik, sebaiknya sebelum melangkah pada pelaksanaan pembelajaran, mempersiapkan kurikulum dan panduan mengajar terhadap guru, sehingga guru dalam pelaksanaan pembelajaran akan lebih terarah, optimal dan tepat sesuai yang diinginkan lembaga kursus, selain itu peserta didik pun mampu mengikuti dan menerima pembelajaran secara optimal.

5.2.2 Agar pelaksanaan pembelajaran berlangsung lancar, selain menggunakan Teaching Guide sebagai panduan, guru juga harus kreatif dalam mengemas proses pembelajaran agar proses pembelajaran menjadi menyenangkan, siswa menjadi antusias dan siswa bisa lebih menikmati proses pembelajaran.

5.2.3 Evaluasi hendaknya dalam setiap lembaga pendidikan ada, karena tahap ini adalah tahap pengukuran kemampuan siswa seperti adanya ujian kenaikan tingkat dan sebagainya, ini bertujuan agar siswa terukur kemampuannya telah mencapai mana, sebagai evaluasi setelah sekian lama belajar dalam lembaga kursus.

5.2.4 Untuk lembaga pendidikan baik formal mau pun non formal yang fokus dalam pendidikan musik, sebaiknya lebih memperkaya dengan pengetahuan tentang metode pembelajaran musik dan penerapannya. 
5.2.5 Untuk menambah wawasan tentang kreatifitas guru tentang improvisasi yang digunakan untuk pembelajaran, guru dapat mengembangkan dengan mencari informasi melalui internet atau pertemuan guru Music Wonderland untuk saling bertukar wawasan dan pikiran.

5.2.6 Guru dapat menambahkan media-media lain, sebagai pendukung dalam pembelajaran seperti alat peraga lain, gerakan-gerakan yang bervariasi, atau video agar siswa lebih tertarik. 


\section{DAFTAR PUSTAKA}

Ahmadi, Abu. 1998. Psikologi Umum. Yogyakarta: Rineka Cipta

D. Sumarno, 1997. Pedoman Pelaksanaan Program Pendidikan Dasar 9 Tahun. Jakarta: CV. Mini Jaya Abadi.

Darsono, 2000. Belajar dan Pembelajaran. Semarang: IKIP Press.

Djamarah, Syaiful Bahri. 2002. Rahasia sukses belajar. Jakarta: Rineka Cipta

Djamarah, Bahri Syaiful, dan Zain Aswan. 2010. Strategi Belajar Mengajar. Jakarta: Rineka Cipta, Edisi revisi. 2010.

Djamaluddin, Abdullah Aly. 1999. Kapita Selekta Pendidikan Islam. Bandung: Pustaka Setia.

Dimyati dan Moedjiono. 2009. Belajar dan Pembelajaran. Jakarta: Rineka Cipta.

Ekosiswoyo, R. 1996. Manajemen Kelas Suatu Upaya Untuk Memperlancar Kegiatan Belajar. Semarang: IKIP Semarang Press

Iswaji, dan Purwanto. 1989. Proses Belajar Mengajar dan Prinsip-Prinsip Belajar, dalam Satmoko (Ed) Psikologi Belajar. Semarang: IKIP Press

Jamalus. 1981. Musik 4. Jakarta: Departemen Pendidikan dan Kebudayaan.

Jamalus. 1988. Musik dan Praktik Perkembangan Buku Sekolah Pendidikan Guru. Jakarta: CV Titik Terang.

Kesumah, Dloyana, dkk. 1995. Pesan-pesan Budaya Lagu-lagu Pop Dangdut dan Pengaruhnya Terhadap Perilaku Sosial Remaja Kota. Jakarta: CV. Eka Putra

Limantara,Cyprianus. 1988. Dasar-dasar Teori Musik. Bandung: Justika

Moleong, Lexy. J. 2006. Metode Penelitian Kualitatif. Bandung: PT. Remaja Rosdakarya.

Mulyana, Deddy. 2008. Ilmu komunikasi. Bandung: PT. Remaja Rosdakarya

Nasution, Harun. 1995. Metode Research (Penelitian Ilmiah). Jakarta: Bumi Aksara.

Hamalik, Oemar. 2001. Proses Belajar Mengajar. Jakarta: Bumi Aksara 
R. Ibrahim \& Nana Syaodih. 2003. Perencanaan Pengajaran. Jakarta: Rineka Cipta

Roestijah, N.K. 1982. Masalah-masalah Ilmu Keguruan. Jakarta: PT Bina Aksara

Sadirman, A.M. 1986. Interaksi dan Motivasi Belajar Mengajar. Jakarta: Rajawali Press

Saifullah, Ali. 1980. Antara Filsafat dan Pendidikan. Surabaya : Usaha Nasional.

Sudjana, N., \& Suryana, H. 1989. Cara belajar siswa aktif dalam proses belajar mengajar. Sinar Baru.

Suharto, S. 2016. "Banyumasan Songs As Banyumas People's Character Reflection." Harmonia: Journal of Arts Research and Education, 49-56.

Retrieved June 5, 2017

(http://journal.unnes.ac.id/nju/index.php/harmonia/article/view/6460).

Suharto and Indriyanto. 2018. "Preserving Calung Banyumasan through

Vocational Education and Its Community." IOP Conference Series:

Materials Science and Engineering 306:12120. Retrieved

(http://stacks.iop.org/1757-

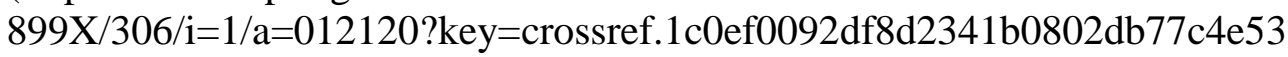

$6)$.

Sudjana, N. (1989). Dasar-dasar Proses Belajar Mengajar. Bandung: Sinarbaru.

Soemarno, D,. 1997. Pedoman Pelaksanaan Disipilin Naional dan Tata Tertib Sekolah. Jakarta : Skala Jamakarya.

Sumaryanto, T. 2007. Pendekatan Kuantitatif dan Kualitatif dalam penelitian pendidikan seni. Semarang: Universitas Negeri Semarang.

Syah, Muhibbin. 1995. Psikologi Pendidikan Suatu Pendekatan Baru. Bandung: Remaja Rosdakarya

Jazuli, M. (2011). MODEL PEMBELAJARAN TARI PENDIDIKAN PADA SISWA SD/MI SEMARANG. Harmonia: Journal of Arts Research and Education, 10(2). doi:https://doi.org/10.15294/harmonia.v10i2.59

Kusumadewi, L., \& Suharto, S. (2011). PENINGKATAN HASIL BELAJAR SENI MUSIK DENGAN MEDIA AUDIO VISUAL MELALUI METODE BERVARIASI. Harmonia: Journal of Arts Research and Education, 10(2). doi:https://doi.org/10.15294/harmonia.v10i2.63 
Adi Sam, T. (2011). PERMAINAN ANAK YANG MENGGUNAKAN NYANYIAN (Kajian Wilayah: Jakarta, Depok, Bogor, Tangerang, dan Bekasi). Harmonia: Journal of Arts Research and Education, 10(2). doi:https://doi.org/10.15294/harmonia.v10i2.57

Suharto, S., Sumaryanto, T., Ganap, V., \& Santosa, S. (2016). Banyumasan Songs As Banyumas People?s Character Reflection. Harmonia: Journal of Arts Research and Education, 16(1), 49-56. doi:https://doi.org/10.15294/harmonia.v16i1.6460

Suharto.(2016). Musikalitas dan Makna Simbolik Pertunjukan Calung Banyumasan di Kabupaten Banyumas. Research Report. Semarang: Lembaga Penelitian Unnes.

Heriwati, S. (2011). METAFORA DALAM CAKEPAN TEMBANG TEMBANG JAWA. Harmonia: Journal of Arts Research and Education, 10(1). doi:https://doi.org/10.15294/harmonia.v10i1.49

PEMANFAATAN DAN PENGEMBANGAN LAGU ANAK-ANAK DALAM PEMBELAJARAN TEMATIK PADA PENDIDIKAN ANAK USIA DINI / TK

Budiarti, M. (2014). KONSEP KEPESINDENAN DAN ELEMEN-ELEMEN DASARNYA. Harmonia: Journal of Arts Research and Education, 13(2). doi:https://doi.org/10.15294/harmonia.v13i2.2781

Hidajat, R. (2014). The Popularity of Waranggana Tayub Malang through Body Exploitation. Harmonia: Journal of Arts Research and Education, 14(2), 72-77. doi:https://doi.org/10.15294/harmonia.v14i2.3288

Widodo, W. (2011). Nuansa Laras Diatonik dalam Macapat Semarangan (Diatonic Scale Atmosphere in Semarang Style Macapat).. Harmonia: Journal of Arts Research and Education, 7(1). doi:https://doi.org/10.15294/harmonia.v7i1.751

Tirtaraharja, Umar. 1990. Pengertian Lingkungan Pendidikan. Jakarta: Departemen Pendidikan dan Kebudayaan.

Utuh, Harun. 1987. Proses Belajar Mengajar. Surabaya: Usaha Nasional Winkel, W.S. 1992. Psikologi Pendidikan. Jakarta: PT. Gramedia 
LAMPIRAN-LAMPIRAN 
INSTRUMEN PENELITIAN

\section{METODE PEMBELAJARAN MUSIK DENGAN PROGRAM MUSIC} WONDERLAND DI HALMAHERA MUSIC SCHOOL SEMARANG.

Pengambilan data dalam penelitian ini menggunakan: (1) Pedoman Observasi, (2) Pedoman Wawancara dan (3) Pedoman Studi Dokumen.

\section{Pedoman Observasi}

Observasi adalah kegiatan pengamatan secara cermat di lapangan terhadap objek penelitian. Dalam observasi terdapat 3 unsur yaitu: (1) Setting, (2) Pelaku dan (3) tindakan. Dalam pengambilan data observasi dilakukan melalui rekaman dapat berupa audio, audio visual atau visual dapat juga dengan pengamatan.Observasi dalam peneitian ini menggunakan teknik observasi terbuka.

\subsection{Setting}

Hal-hal yang diobservasi meliputi:

\subsubsection{Lokasi Penelitian}

1.1.1.1 Apa nama lokasi yang diteliti

1.1.1.2 Siapa pendiri lokasi penelitian 
1.1.1.3 Kapan lokasi penelitian didirikan

1.1.1.4 Dimana letak lokasi penelitian

1.1.1.5 Mengapa lokasi penelitian didirikan

1.1.1.6 Bagaimana sejarah didirikannya lokasi penelitian

\subsubsection{Sarana dan Prasarana}

1.1.2.1 Apa saja sarana dan prasarana yang ada di Halmahera Music School.

1.1.2.2 Siapa yang menggunakan sarana dan prasarana di Halmahera Music School.

1.1.2.3 Kapan sarana dan prasarana digunakan di Halmahera Music School.

1.1.2.4 Dimana sarana dan prasarana berada di Halmahera Music School.

1.1.2.5 Mengapa sarana dan prasarana digunakan di Halmahera Music School.

1.1.2.6 Bagaimana sarana dan prasarana digunakan di Halmahera Music School.

1.2 Pelaku

1.2.1 Guru / Instruktur di Halmahera Music School.

1.2.1.1 Siapa saja yang mengajar di Halmahera Music School.

1.2.1.2 Apa yang diajarkan oleh guru di Halmahera Music School.

1.2.1.3 Kapan guru mengajarkan pembelajaran Music Wonderland di Halmahera Music School.

1.2.1.4 Dimana guru mengajarkan pembelajaran Music Wonderland di Halmahera Music School. 
1.2.1.5 Mengapa guru mengajarkan pembelajaran Music Wonderland di Halmahera Music School.

1.2.1.6 Bagaimana guru mengajarkan pembelajaran Music Wonderland di Halmahera Music School.

\subsubsection{Siswa}

1.2.2.1 Apa yang diikuti siswa di Halmahera Music School Semarang.

1.2.2.2 Siapa yang mengikuti pembelajaran di Halmahera Music School Semarang.

1.2.2.3 Kapan siswa mengikuti pembelajaran di Halmahera Music School Semarang.

1.2.2.4 Dimana siswa mengikuti pembelajaran Halmahera Music School Semarang.

1.2.2.5 Mengapa siswa mengikuti pembelajaran di Halmahera Music School Semarang.

1.2.2.6 Bagaimana siswa mengikuti pembelajaran di Halmahera Music School Semarang.

\subsection{Tindakan}

1.3.1.1 Terkait dengan materi ajar pembelajaran Music Wonderland di Halmahera Music School.

1.3.1.2 Apa saja materi ajar yang digunakan dalam pembelajaran Music Wonderland di Halmahera Music School.

1.3.1.3 Siapa yang menggunakan materi ajar dalam pembelajaran Music Wonderland di Halmahera Music School. 
1.3.1.4 Dimana materi ajar tersebut digunakan dalam pembelajaran Music Wonderland di Halmahera Music School.

1.3.1.5 Kapan materi ajar tersebut digunakan dalam pembelajaran Music Wonderland di Halmahera Music School.

1.3.1.6 Mengapa materi ajar tersebut digunakan dalam pembelajaran Music Wonderland di Halmahera Music School.

1.3.1.7 Bagaimana materi ajar tersebut digunakan dalam pembelajaran Music Wonderland di Halmahera Music School.

1.3.2 Yang dilakukan oleh guru

1.3.2.1 Apa metode pembelajaran yang digunakan di Halmahera Music School?

1.3.2.1 Apa yang dilakukan guru dalam pembelajaran Music Wonderland di Halmahera Music School Semarang.

1.3.2.2 Bagaimana penerapan Music Wonderland yang baik di Halmahera Music School?

1.3.2.3 Bagaimana gambaran umum tentang pembelajaran Music Wonderland di Halmahera Music School?

1.3.2.4 Apa kelebihan dan kekurangan pembelajaran Music Wonderland di Halmahera Music School?

1.3.2.5 Bagaimana hasil dari pembelajaran Music Wonderland di Halmahera Music School?

1.3.2.6 Apa saja kendala yang ditemui dalam pembelajaran Music Wonderland di Halmahera Music School? 
1.3.2.7 Siapa yang memberikan pembelajaran Music Wonderland di Halmahera Music School Semarang.

1.3.2.8 Kapan guru memberikan pembelajaran Music Wonderland di Halmahera Music School Semarang.

1.3.2.9 Dimana guru memberikan pembelajaran Music Wonderland di Halmahera Music School Semarang.

1.3.2.10 Mengapa guru memberikan pembelajaran Music Wonderland di Halmahera Music School Semarang.

1.3.2.11 Bagaimana guru memberikan pembelajaran Music Wonderland di Halmahera Music School Semarang.

\subsubsection{Yang dilakukan siswa}

1.3.3.1 Apa yang dilakukan siswa dalam pembelajaran Music Wonderland di Halmahera Music School Semarang.

1.3.3.2 Kapan siswa melakukan pembelajaran Music Wonderland di Halmahera Music School Semarang.

1.3.3.3 Dimana siswa melakukan pembelajaran Music Wonderland di Halmahera Music School Semarang.

1.3.3.4 Mengapa siswa melakukan pembelajaran Music Wonderland di Halmahera Music School Semarang.

1.3.3.5 Bagaimana siswa melakukan pembelajaran Music Wonderland di Halmahera Music School Semarang.

1.3.3.6 Apakah siswa tertarik dengan pembelajaran Music Wonderland? 
1.3.3.7 Bagaimanakah respon siswa mengenai pembelajaran Music Wonderland?

1.3.3.8 Apakah yang menandakan bahwa siswa berhasil dalam pembelajaran tersebut?

\section{Pedoman Wawancara}

Wawancara adalah bentuk komunikasi antara dua orang, melibatkan seseorang yang ingin memperoleh informasi dari seorang lainnya dengan mengajukan pertanyaan-pertanyaan, berdasarkan tujuan tertentu (Mulyana, 2008: 180). Sebelum diadakan wawancara peneliti terlebih dahulu menyiapkan beberapa pertanyaan-pertanyaan agar pelaksanaannya dapat terarah sesuai dengan tujuan yang ingin dicapai. Metode wawancara digunakan karena jika hanya melalui observasi saja, dirasa belum memadai untuk memperoleh data yang dibutuhkan sehingga perlu adanya teknik lain untuk melengkapi. Melalui wawancara akan diperoleh data yang lebih spesifik dan akurat atau khusus sesuai dengan tujuan penelitian.

Wawancara dalam penelitian ini dilaksanakan kepada General Manager di Halmahera Music School Semarang.

2.1 Daftar pertanyaan tentang gambaran umum lokasi penelitian yaitu:

2.1.1 Apa nama sekolah ini?

2.1.2 Siapa pendiri Halmahera Music School?

2.1.3 Kapan Halmahera Music School resmi didirikan?

2.1.4 Dimana letak geografis Halmahera Music School?

2.1.5 Mengapa Halmahera Music School didirikan? 
2.1.6 Bagaimana sejarah singkat mengenai berdirinya Halmahera Music School?

2.1.7 Berapa luas wilayah Halmahera Music School?

2.1.8 Apa saja sarana dan prasarana yang ada di Halmahera Music School?

2.1.9 Digunakan untuk apa sarana dan prasarana yang ada di Halmahera Music School?

2.1.10 Berapakah jumlah siswa yang kursus musik Music Wonderland?

2.1.11 Berapa jumlah siswa yang ada di Halmahera Music School?

2.1.12 Berapa jumlah kelas yang ada di Halmahera Music School?

2.1.13 Bagaimana kondisi siswa dan guru di Halmahera Music School?

2.1.14 Berapakah jumlah guru yang ada sampai saat ini di Halmahera Music School?

2.2 Daftar pertanyaan kepada guru Music Wonderland yang berkaitan dengan metode pembelajaran musik dengan program music wonderland di Halmahera Music School Semarang:

2.2.1 Apakah ada batasan umur untuk kelas Music Wonderland Halmahera Music School?

2.2.2 Bagaimanakah sistem pembelajaran Music Wonderland di Halmahera Music School?

2.2.3 Berapakah peserta dari setiap kelas Music Wonderland di Halmahera Music School?

2.2.4 Berapakah durasi waktu yang dipakai pada kelas Music Wonderland di Halmahera Music School? 
2.2.5 Apa yang dipersiapkan guru sebelum mengajar?

2.2.6 Apa saja tujuan untuk mempersiapkan hal-hal tersebut?

2.2.7 Apakah metode pembelajaran yang digunakan dalam kelas Music Wonderland di Halmahera Music School?

2.2.8 Menurut Anda, apakah pembelajaran Music Wonderland sangat bermanfaat bagi anak usia dini?

2.2.9 Apakah seluruh siswa Music Wonderland dapat mengikuti kegiatan pembelajaran dengan baik?

2.2.10 Bagaimana solusi Anda ketika terdapat siswa yang tidak dapat mengikuti kegiatan pembelajaran dengan baik?

2.2.11 Bagaimana hasil dari pembelajaran Music Wonderland di Halmahera Music School?

2.2.12 Apa saja kendala yang ditemui dalam pembelajaran Music Wonderland di Halmahera Music School?

2.2.13 Apa saran Anda untuk perbaikan terhadap pembelajaran Music Wonderland di Halmahera Music School?

2.2.14 Apakah siswa tertarik dengan pembelajaran Music Wonderland di Halmahera Music School?

2.2.15 Apa harapan Anda mengenai pembelajaran Music Wonderland di Halmahera Music School?

2.3 Daftar pertanyaan kepada siswa Music Wonderland yang berkaitan dengan metode pembelajaran musik dengan program music wonderland di Halmahera Music School Semarang 
2.3.1 Bagaimana rasanya ikut les Music Wonderland?

2.3.2 Kapan waktu lesnya?

2.3.3 Apakah kamu bisa mengikuti kegiatan pembelajaran Music Wonderland dengan baik?

2.3.4 Apa saja kegiatan yang dilakukan di dalam kelas?

\section{Pedoman Dokumentasi}

(1) Gambaran Umum Sekolah (Sejarah, letak geografis, luas dan lain-lain)

(2) Sarana dan Prasarana penunjang kegiatan pembelajaran

(3) Lagu-lagu yang digunakan untuk kegiatan pembelajaran

(4) Perangkat Pembelajaran

(5) Dokumentasi kegiatan pembelajaran atau kegiatan lain yang sudah ada

(6) Gambar dokumentasi yang diambil saat penelitian kegiatan berlangsung.

\section{Responden Penelitian}

\section{DAFTAR RESPONDEN PENELITIAN}

\begin{tabular}{|c|l|l|}
\hline No & \multicolumn{1}{|c|}{ Nama Lengkap } & \multicolumn{1}{|c|}{ Keterangan } \\
\hline 1 & Sherly Marcella Djajakusuma & General Manager \\
\hline 2 & Murtini Hartawidjaja & Guru Music Wonderland \\
\hline 3 & Annetha Steffi & Siswa \\
\hline
\end{tabular}


Responden : General Manager Halmahera Music School

$\begin{array}{ll}\text { Nama } & : \text { Sherlly Marcella Djajakusuma } \\ \text { Umur } & : 25 \text { Tahun }\end{array}$

Hari, tanggal : Senin, 5 September 2016

Tempat : Depan Ruang Owner Halmahera Music School. 


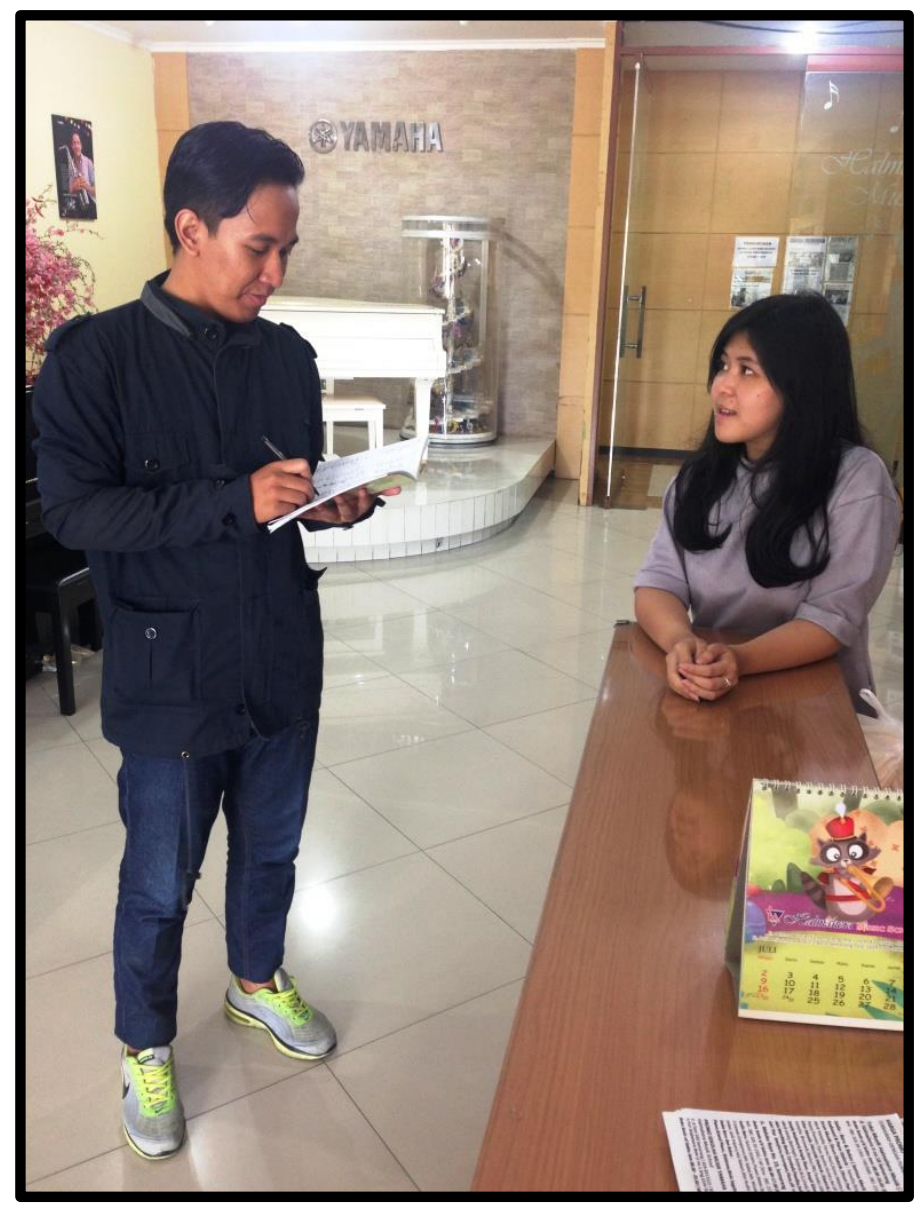

Wawancara dengan General Manager Halmahera Music School (foto Didi Hermanto 2016)

Daftar Pertanyaan:

Mengenai Gambaran Umum Halmahera Music School

- Apa nama sekolah ini?

Jawaban: Namanya ya Halmahera Music School.

- Siapa pendiri Halmahera Music School? 
Jawaban: yang mendirikan yaitu papah saya sendiri, Bapak Tresna Djajakusuma.

- Kapan Halmahera Music School resmi didirikan?

Jawaban: untuk resminya sih per tanggal 1 Nopember 2012,

- Dimana letak geografis Halmahera Music School?

Jawaban: di Jalan Ahmad Yani nomer 193 Semarang. Persisnya di sebelah Bank Mandiri, depan Indomart.

- Mengapa Halmahera Music School didirikan?

Jawaban: sebenarnya kepentingan bisnis, tapi biar bagaimanapun musik sekarang sangat diminati semua kalangan dan semua usia, maka dari itu musik sebagai lahan bisnis yang tepat ketika peminatnya menjamur, selain itu di dalam lembaga pendidikan formal, seperti SMA, SMP, SD dan lain sebagainya, hampir sebagian besar sekolah ada kurikulum seni budaya yang mewajibkan bisa alat musik atau pun bernyanyi, ini juga menambah peluang besar dalam berbisnis sekolah musik, sebagai tempat para siswa dalam mendapatkan ilmu tentang musik di pendidikan non formal.

- Bagaimana sejarah singkat mengenai berdirinya Halmahera Music School? Jawaban: berdirinya Halmahera Music School berawal dari tempat penjualan alat musik dan soundsystem kamidi Semarang yang bernama Halmahera Musik. Di Halmahera Musik, merk Yamaha merupakan salah satu yang kami jual.kami sudah bekerjasama dengan baik dan sudah terjalin sejak lama antara dengan Yamaha Musik, kemudian bertepatan juga pasca berhentinya kerjasama antara YMI dengan salah satu sekolah musik ternama di Semarang 
yaitu Purnomo Music School, dan kemudian dari pihak YMI menawarkan kerjasama kepada kami untuk membuka sekolah musik dengan lisensi dari YMI, yaitu Yamaha Music School. Pada awalnya, tawaran dari YMI tersebut belum kami respoin, namun dari YMI memberikan tawaran tersebut hingga berulang kali, sampai kemudian Papa saya, yaitu bapak Tresna Djajakusuma yang sekaligus sebagai pemilik Halmahera Musik, pada akhirnya memutuskan untuk bekerjasama dengan YMI untuk membuat sekolah musik dengan lisensi Yamaha Music School tersebut .

- Berapa luas wilayah Halmahera Music School?

Jawaban: yang di jalan A. Yani mungkin sekitar -/+ $1500 \mathrm{~m}^{2 .}$, dan yang di Puri Anjasmoro hampir dua kali lipatnya.

- Apa saja sarana dan prasarana yang ada di Halmahera Music School?

Jawaban: ya pastinya ada ruang kelas, showroom, ruang guru lahan parkir, mushola, ruang tunggu dan lain-lain nanti bisa dilihat sendiri.

- Digunakan untuk apa sarana dan prasarana yang ada di Halmahera Music School?

Jawaban: pastinya itu untuk menunjang pembelajaran, kemudian memberikan kenyamanan juga, kalau ruang guru ya untuk tempat guru transit, tempat parkir, mushola, dan sebagainya itu untuk kenyamanan yang kami sediakan untuk semua yang ada di sini.

- Berapa jumlah siswa yang ada di Halmahera Music School?

Jawaban: untuk jumlah siswa sendiri, jumlahnya hampir mencapai 2000 siswa di kedua sekolah musik, maksudnya di A. Yani dan Puri. 
- Berapakah jumlah siswa yang kursus musik Electone?

Jawaban : Sekitar 340 siswa.

- Berapa jumlah kelas yang ada di Halmahera Music School yang digunakan untuk pembelajaran Music Wonderland?

Jawaban: jumlah kelas yang di A. Yani ada 2 kelas, kalo yang di Puri ada 3 kelas.

- Bagaimana kondisi siswa dan guru di Halmahera Music School?

Jawaban: Sampai saat ini baik, semua normal, karena disini guru-gurunya sudah linsensi Yamaha, jadi sudah dipersiapkan Yamaha seprofesional mungkin.

- Berapakah jumlah guru yang ada sampai saat ini di Halmahera Music School? Jawaban: semuanya ada 40 orang guru.

\section{Responden : Guru Kelas Music Wonderland Halmahera Music School.}

Nama $\quad$ : Murtini Hartawidjaja

Umur $\quad: 54$ Tahun

Hari, tanggal : Selasa, 6 September 2016

Tempat $\quad$ : Ruang Guru Halmahera Music School 
Daftar Pertanyaan Mengenai Pembelajaran Musik dengan Program Music Wonderland di Halmahera Music School:

- Apakah ada batasan umur untuk kelas Music Wonderland di Halmahera Music School?

Jawaban: Ya, tentu ada, sesuai yang menjadi ketentuan dari Yamaha, batasan umur untuk kelas Music Wonderland antara usia 3-4 tahun.

- Bagaimanakah sistem pembelajaran Music Wonderland di Halmahera Music School?

Jawaban: kalau Music Wonderland itu semuanya kelas group, jadi group lesson belajar bersama-sama, karena tidak ada kelas privat (sendirian dalam satu kelas)

- Berapakah peserta setiap kelas Music Wonderland di Halmahera Music School?

Jawaban: setiap kelas Music Wonderland maksimal 10 siswa, jadi jika kurang dari 10 boleh, tapi tidak boleh lebih dari 10 siswa.

- Berapakah durasi waktu yang dipakai pada kelas Music Wonderland di Halmahera Music School?

Jawaban: semuanya 1 jam atau 60 menit.

- Apa yang dipersiapkan guru sebelum mengajar?

Jawaban : Guru terlebih dahulu mempersiapkan materi yang akan diajarkan dikelas pastinya, seperti buku teks, gambar-gambar, bahan pembicaran untuk membuat suasana menjadi lebih menyenangkan, kemudian harus dalam kondisi mood yang baik, jadi sebelum mengajar segala permasalahan 
harus disingkirkan dulu agar mengajar tetap maksimal. Kemudian stiker, ini juga perlu untuk reward dan lainnya.

- Apa saja tujuan untuk mempersiapkan hal-hal tersebut?

Jawaban : Ya seperti yang saya jelaskan tadi ada buku teks untuk bahan ajar di kelas, kemudian ada mood yang baik demi kelancaran dalam mengajar, suasana juga akan menjadi menyenangkan dan siswa juga akan lebih nyaman dalam mengikuti pelajaran. Selain itu ada stiker, ya stiker ada beberapa jenis disini, seperti stiker yang dipakai untuk penghargaan stelah anak-anak mair dalam aktifitas tertentu, kemudian ada juga stiker untuk kehadiran, siswa biasanya menempelkan di workbook mereka.

- Apakah metode pembelajaran yang digunakan dalam kelas Music Wonderland di Halmahera Music School?

Jawaban: Metode yang saya gunakan yaitu dengan demonstrasi, tujuannya agar anak-anak mengikuti gerakan-gerakan yang saya praktekkan.

- Menurut Anda, apakah pembelajaran Music Wonderland sangat bermanfaat bagi anak-anak?

Jawaban: Sangat, kenyataannya anak-anak yang telah selesai mengikuti program Music Wonderland, anak-anak lebih fokus, terutama masalah tempo, mereka jadi lebih baik, dan sebenarnya program ini tujuannya ya untuk itu.

- Apakah seluruh siswa Music Wonderland dapat mengikuti kegiatan pembelajaran dengan baik? 
Jawaban: kebanyakan sih bisa mengikuti, walau terkadang ada satu dua peserta yang jadi troublemaker, tapi saya maklumi itu semua dan itu tantangan tersendiri bagi guru Music Wonderland.

- Bagaimana solusi Anda ketika terdapat siswa yang tidak dapat mengikuti kegiatan pembelajaran dengan baik?

Jawaban: Saya biarkan saja, paling saya minta bantuan orang tua untuk mengondisikan anak tersebut. Mereka yang tidak bisa mengikuti kegiatan dengan baik biasanya karena mereka main sendiri sama temennya. Intinya peran serta orang tua memang sangat penting.

- Bagaimana hasil dari pembelajaran Music Wonderland di Halmahera Music School?

Jawaban: ya itu tadi, anak-anak yang sebelumnya susah mengikuti tempo musik, mereka jadi bisa mengikuti, itu sih yang paling utama. Selebihnya, daya anak-anak meningkat, daya imajinasi yang tinggi.

- Apa saja kendala yang ditemui dalam pembelajaran Music Wonderland di Halmahera Music School?

Jawaban: apa ya, paling ya itu harus sabar mengendalikan anak-anak yang susah diatur. Modal sabar harus tinggi, tapi wajar sih karena emang anakanak ya begitu.

- Apa saran Anda untuk perbaikan terhadap pembelajaran Music Wonderland di Halmahera Music School?

Jawaban: sementara ini tidak ada, saya merasa sudah pas. 
- Apakah siswa tertarik dengan pembelajaran Music Wonderland di Halmahera Music School?

Jawaban: anak-anak sangat antusias, karena pembelajaran Music Wonderland penuh dengan musik dan gambar.

- Apa harapan Anda mengenai pembelajaran Music Wonderland di Halmahera Music School ?

Jawaban: harapan saya agar program ini lebih eksis lagi, karena manfaat untuk anak-anak yang sangat baik untuk kedepannya.

Responden : Siswa Music Wonderland Halmahera Music School.

Nama : Annetha Steffi

Umur $\quad: 4$ Tahun 
Hari, tanggal : Selasa, 6 September 2016

Tempat : Di depan Ruangan Kelas “Angry Bird”

Daftar Pertanyaan:

- Les apa aja yang kamu ikuti?

Jawaban: Aku Cuma ikut wonderland aja.

- Bagaimana rasanya ikut les Music Wonderland?

Jawaban: Suka, soalnya musiknya asik.

- Dimana les yang diikuti?

Jawaban: Di ruang "Angry Bird”

- Kapan waktu lesnya?

Jawaban: Hari ini (Selasa) jam 6 sore

- Apakah kamu bisa mengikuti kegiatan pembelajaran Music Wonderland dengan baik?

Jawaban: Bisa

- Apa saja kegiatan yang dilakukan di dalam kelas?

Jawaban: Di dalam kelas tu joget-joget, sambil pencet-pencet Electone.

- Selama les Music Wonderland, apa saja yang kamu dapat?

Jawaban: Seneng, bisa ketemu banyak temen baru. 


\section{DOKUMENTASI}

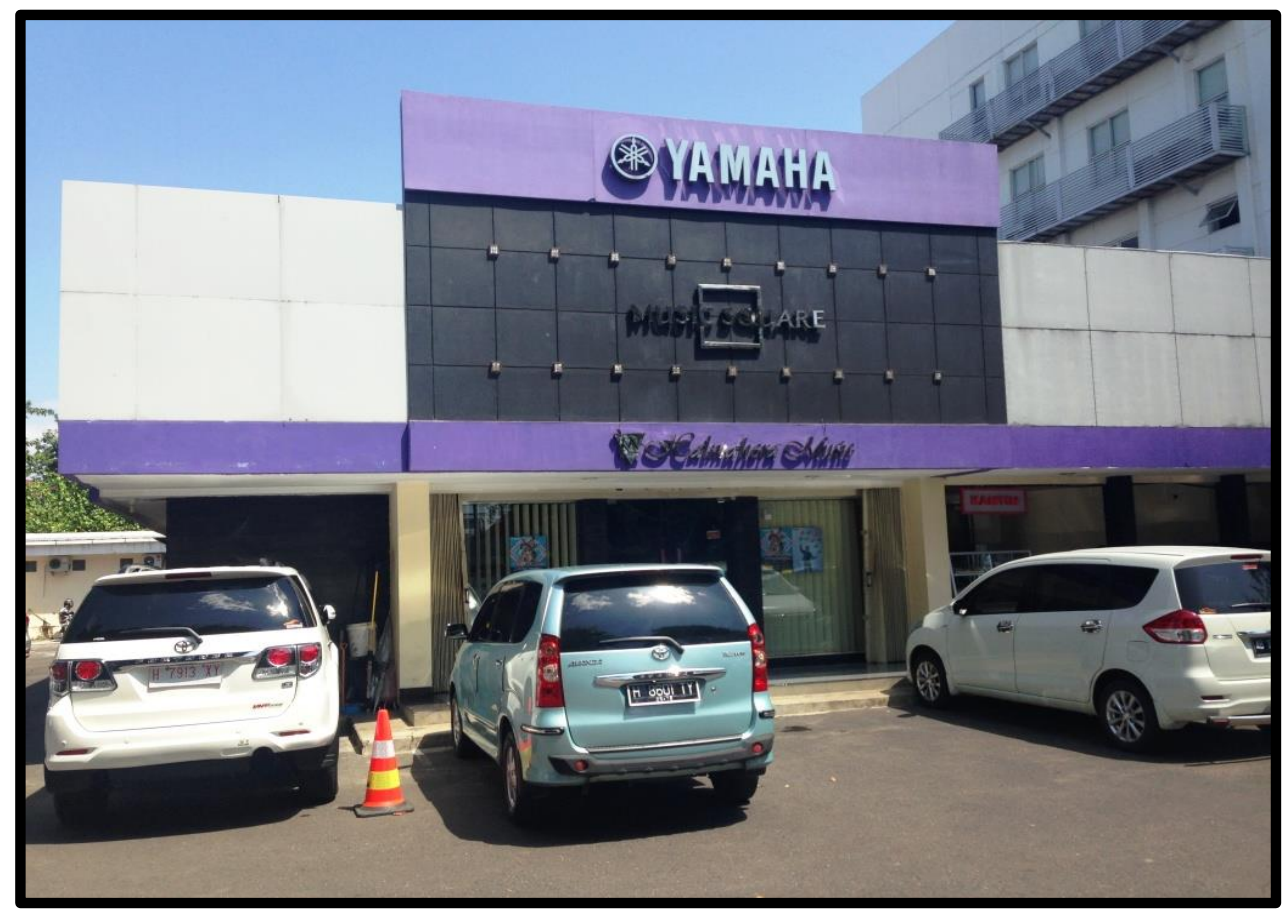

Gambar 1. Tampak bagian depan Halmahera Music School A. Ayani

(Dokumentasi 2016, oleh Didi Hermanto)

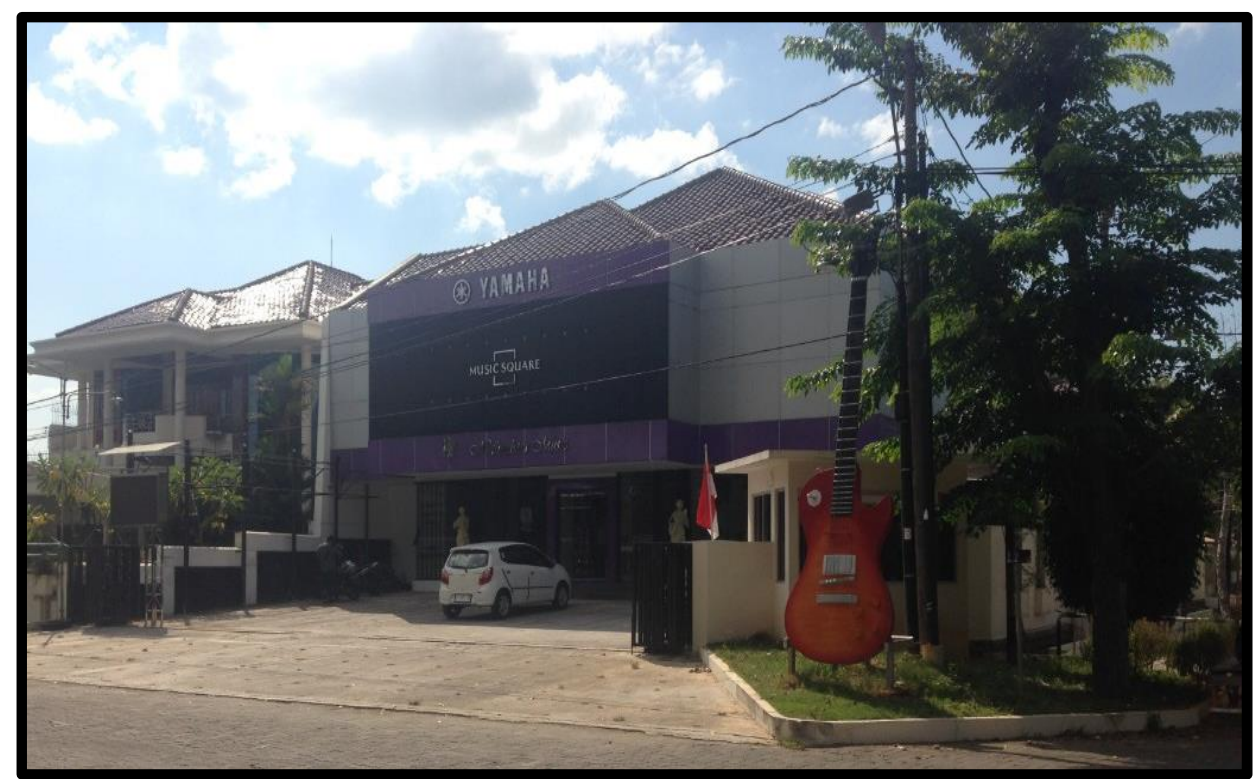

Gambar 2. Tampak bagian depan Halmahera Music School Puri Anjasmoro

(Dokumentasi 2016, oleh Didi Hermanto) 


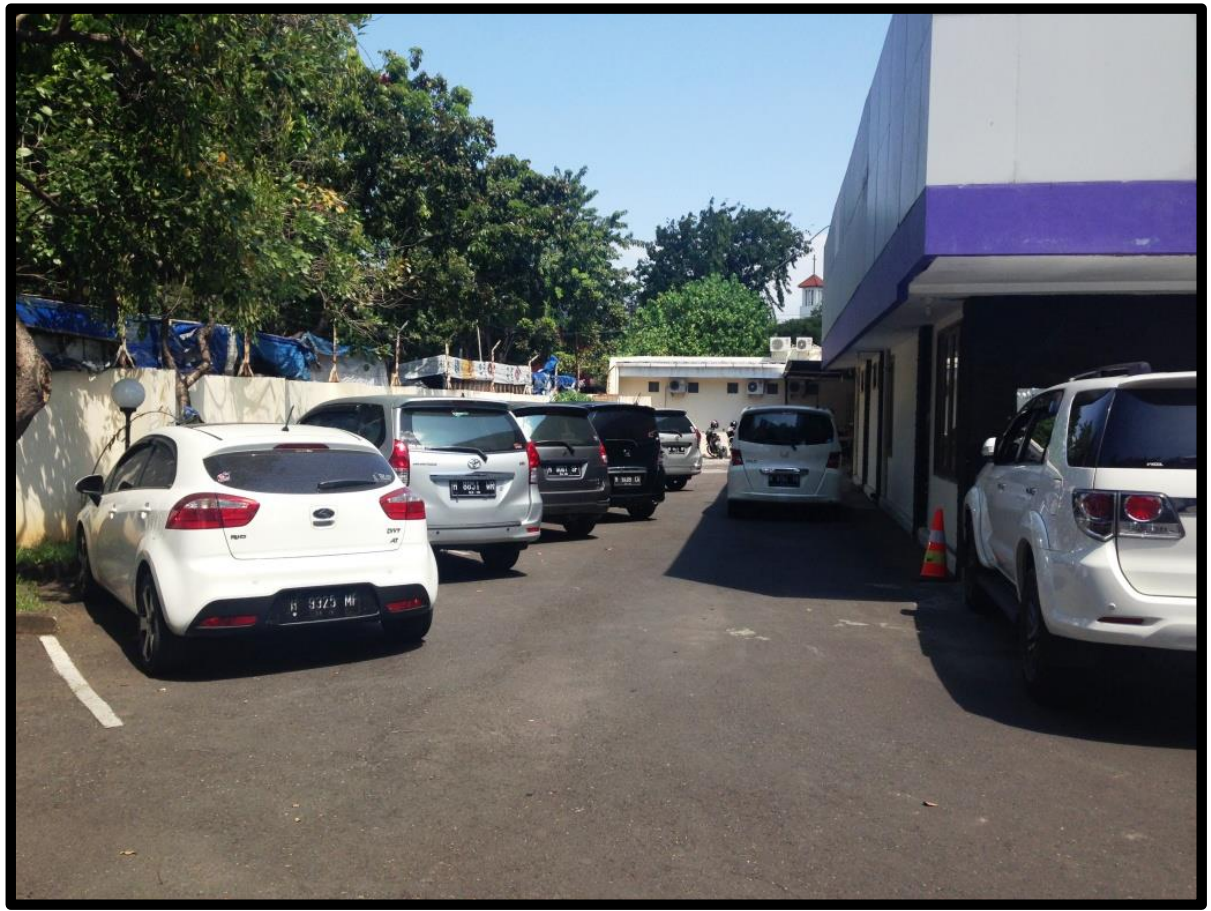

Gambar 3. Foto parkiran mobil Halmahera Music School A. Yani

(Dokumentasi 2016, oleh Didi Hermanto)

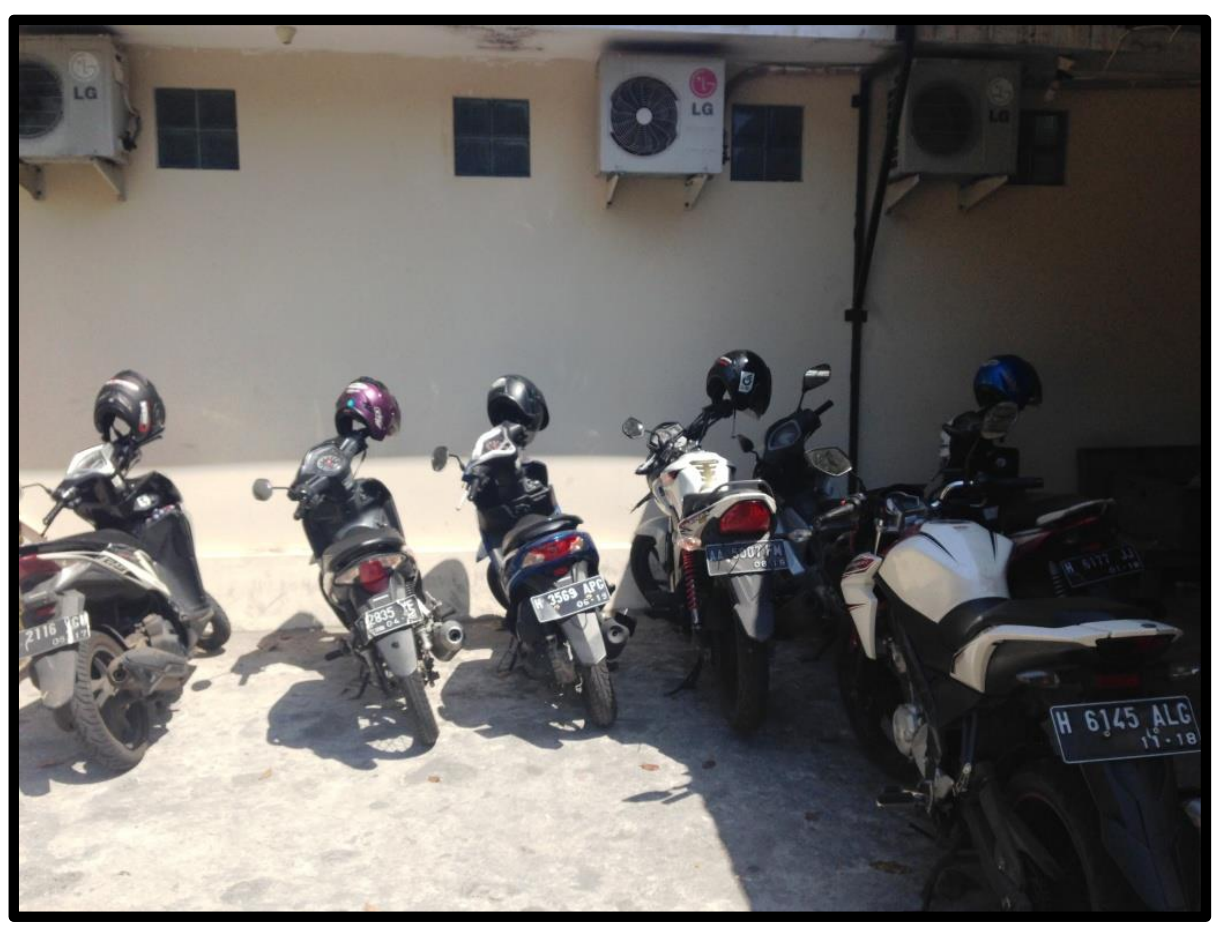

Gambar 4. Foto parkiran motor Halmahera Music School A. Yani (Dokumentasi 2016, oleh Didi Hermanto) 


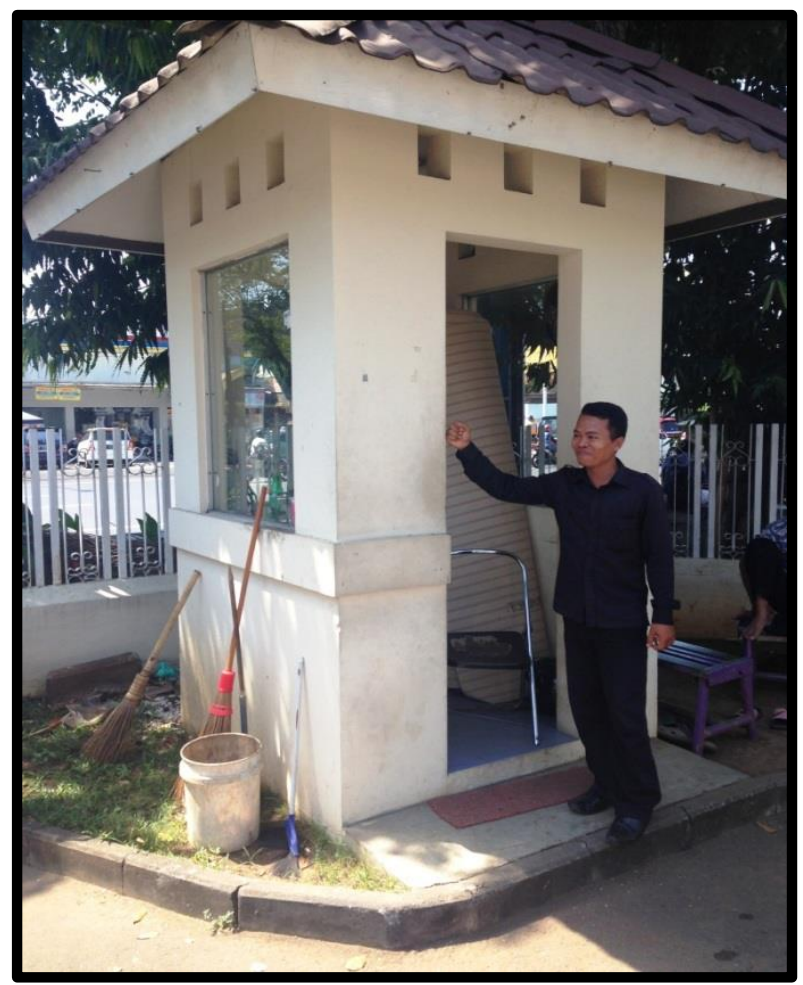

Gambar 5. Foto Pos Satpam Halmahera Music School A. Yani (Dokumentasi 2016, oleh Didi Hermanto)

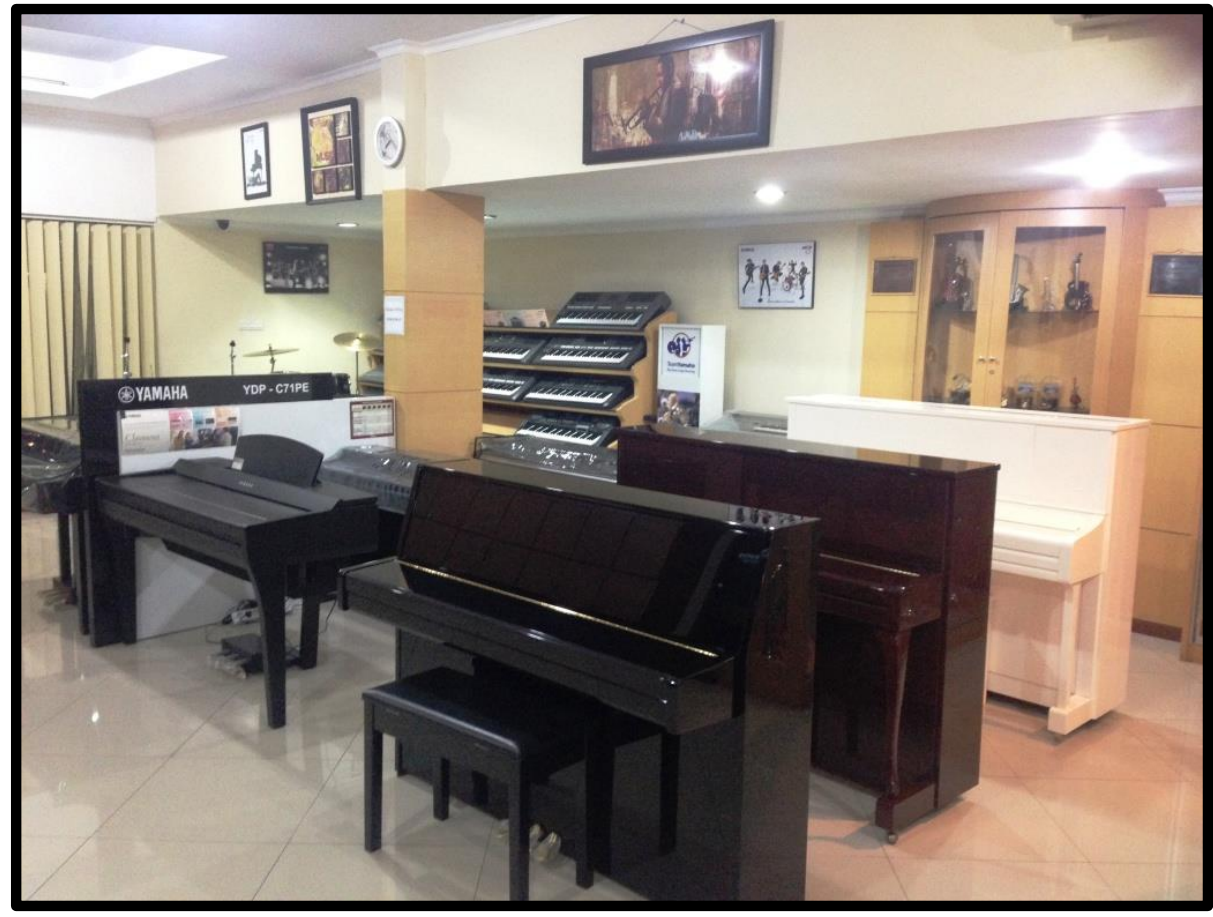

Gambar 6. Showroom Alat Musik Halmahera Music School A. Yani (Dokumentasi 2016, oleh Didi Hermanto) 


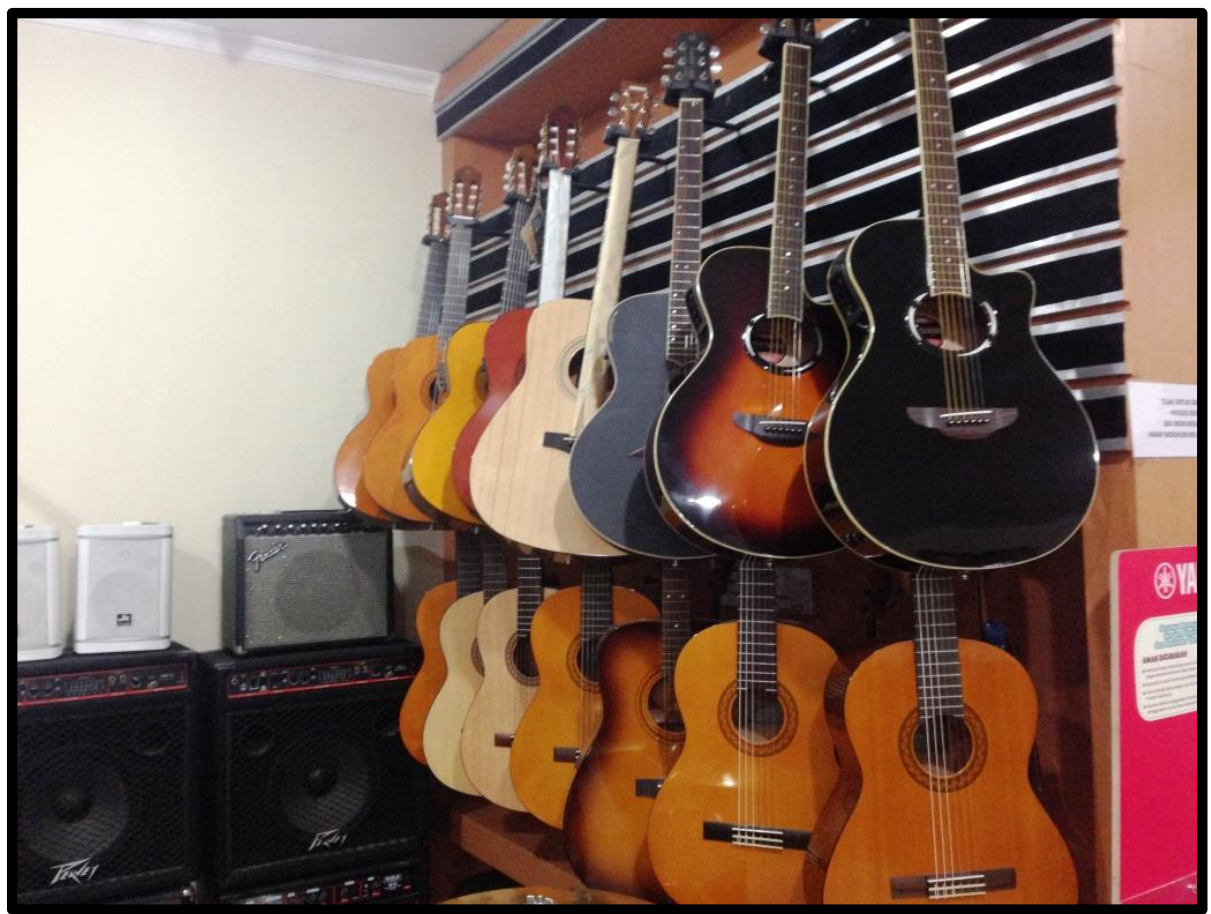

Gambar 7. Showroom Alat Musik Halmahera Music School A. Yani (Dokumentasi 2016, oleh Didi Hermanto)

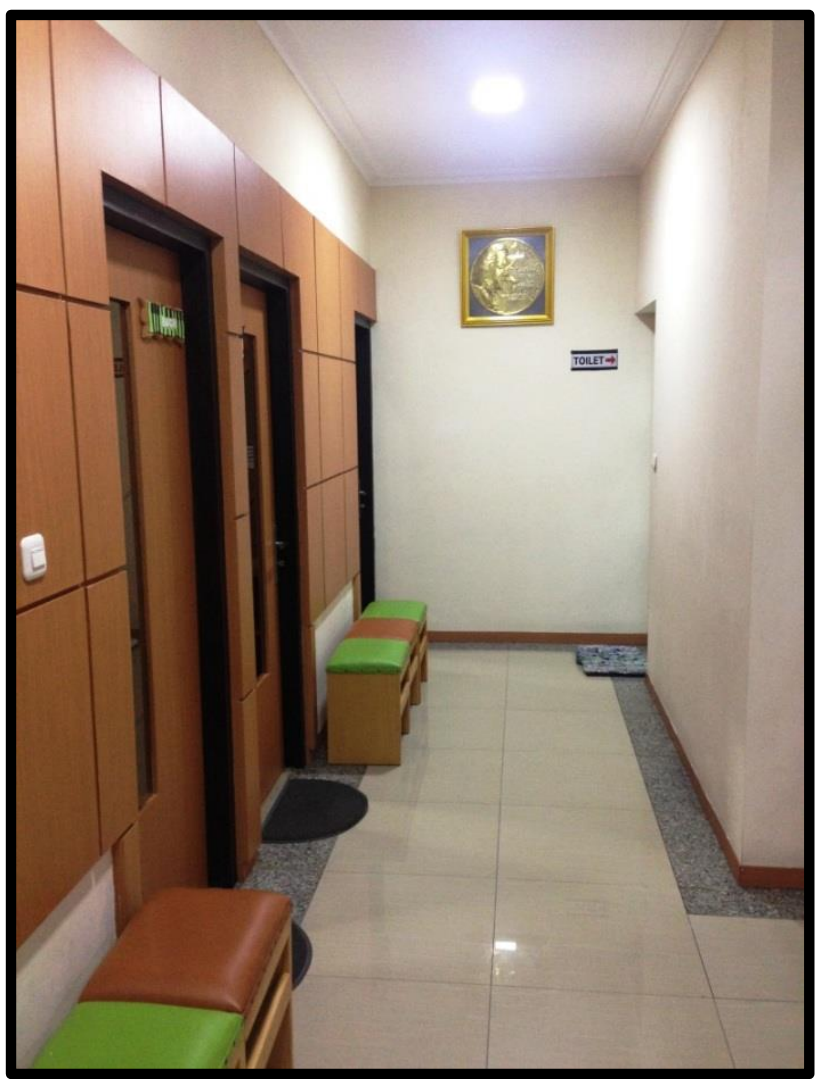

Gambar 8. Toilet Halmahera Music School Puri Anjasmoro (Dokumentasi 2016, oleh Didi Hermanto) 


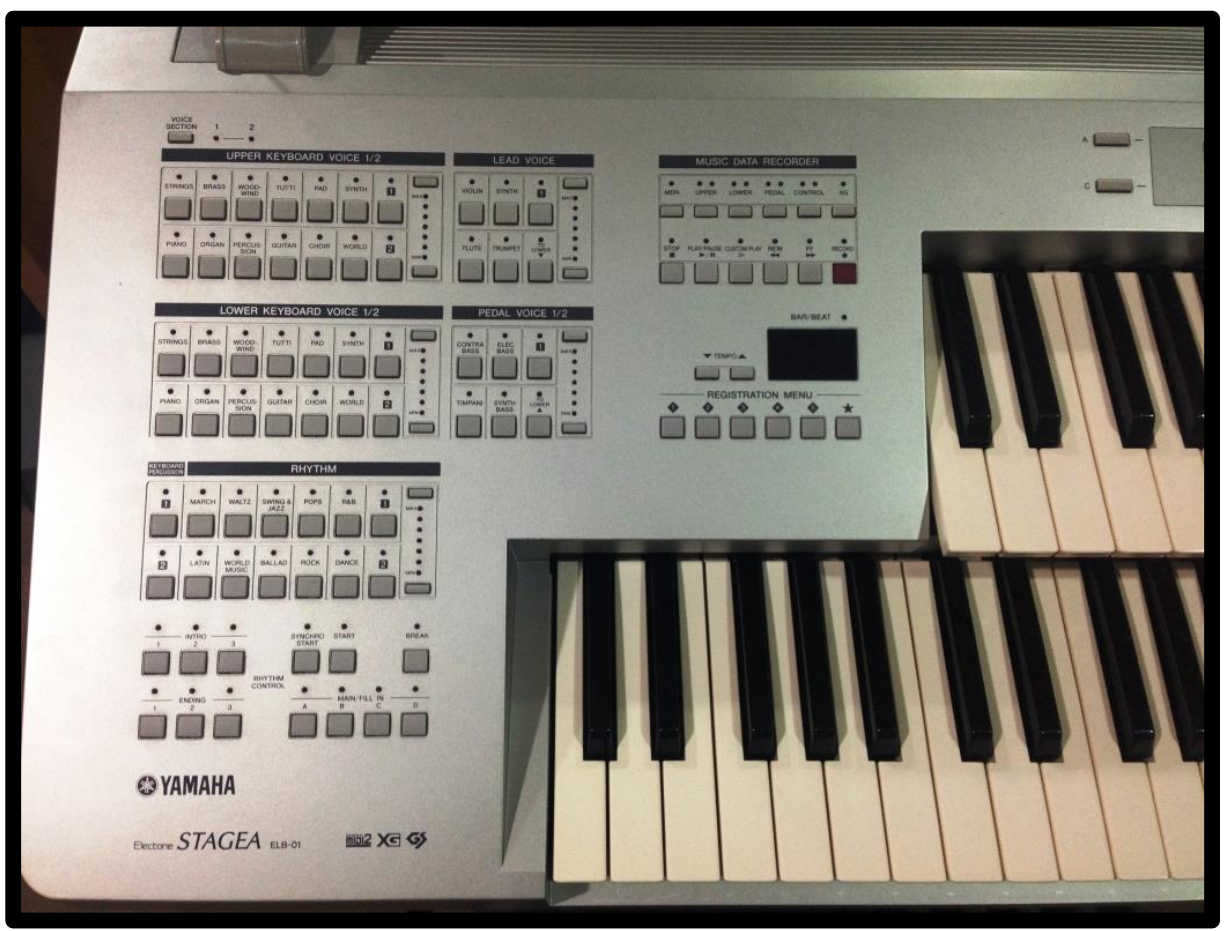

Gambar 9. Electone Yamaha STAGEA ELB-01

(Dokumentasi 2016, oleh Didi Hermanto)

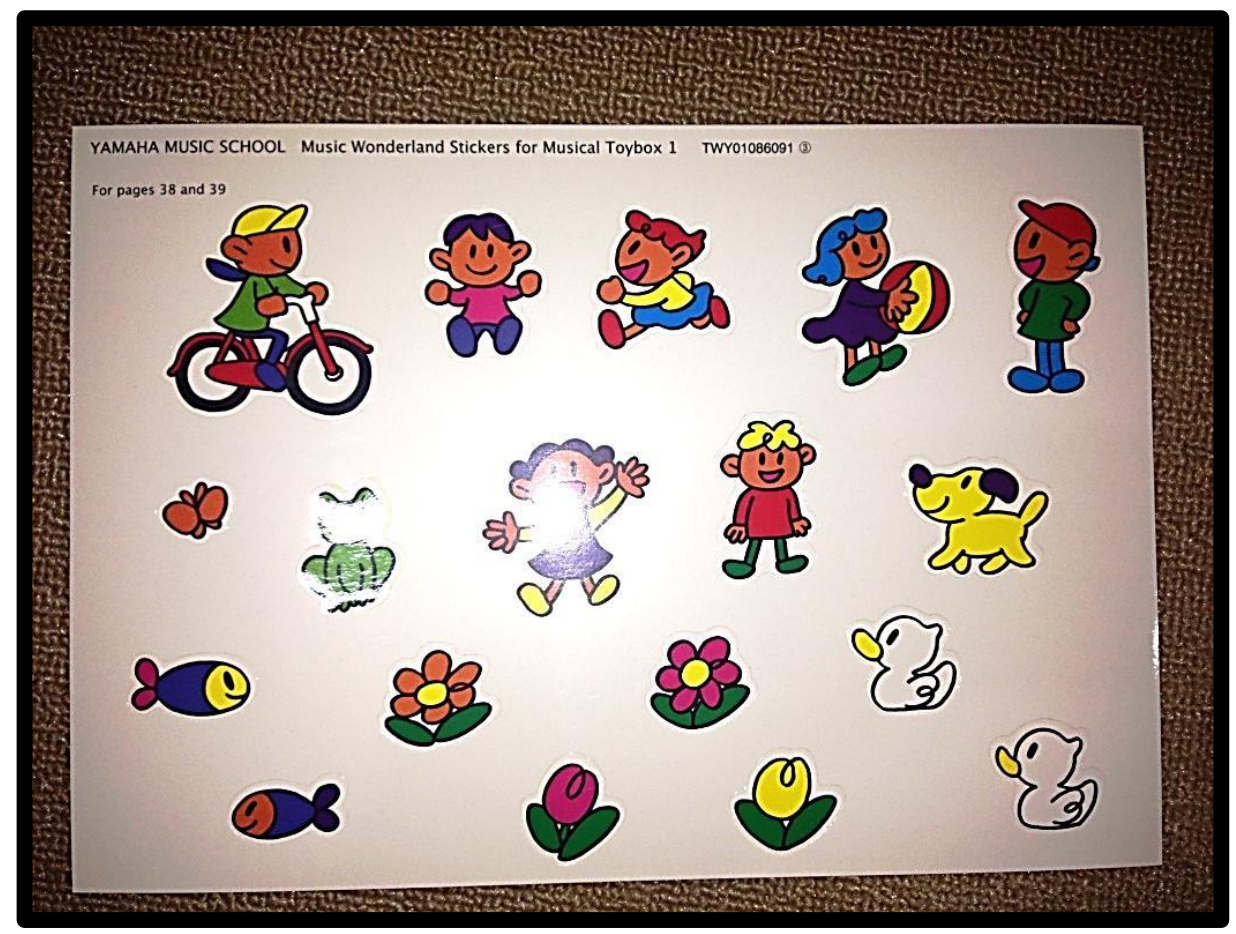

Gambar 10. Sticker yang diberikan kepada siswa sebagai bukti kehadiran (Dokumentasi 2016, oleh Didi Hermanto) 


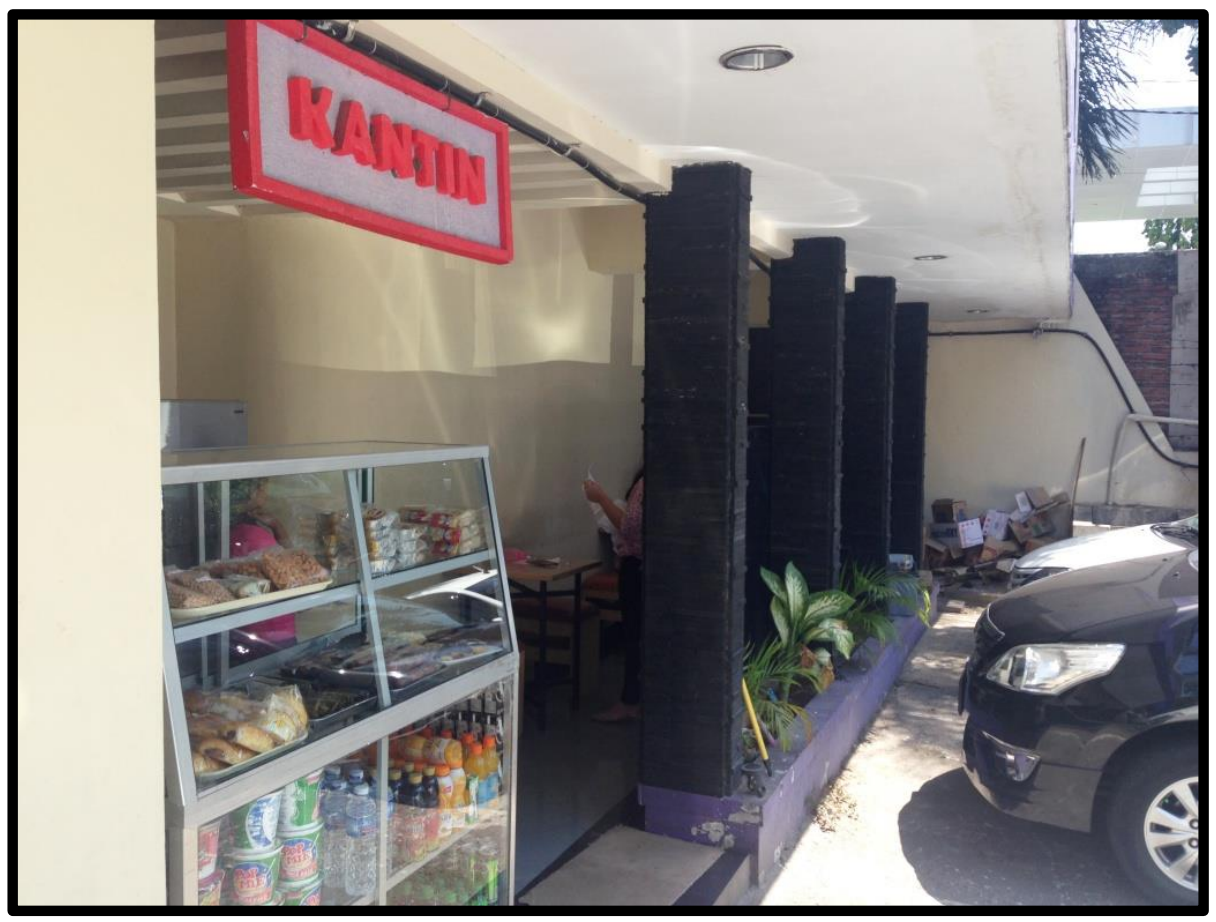

Gambar 11. Kantin

(Dokumentasi 2016, oleh Didi Hermanto)

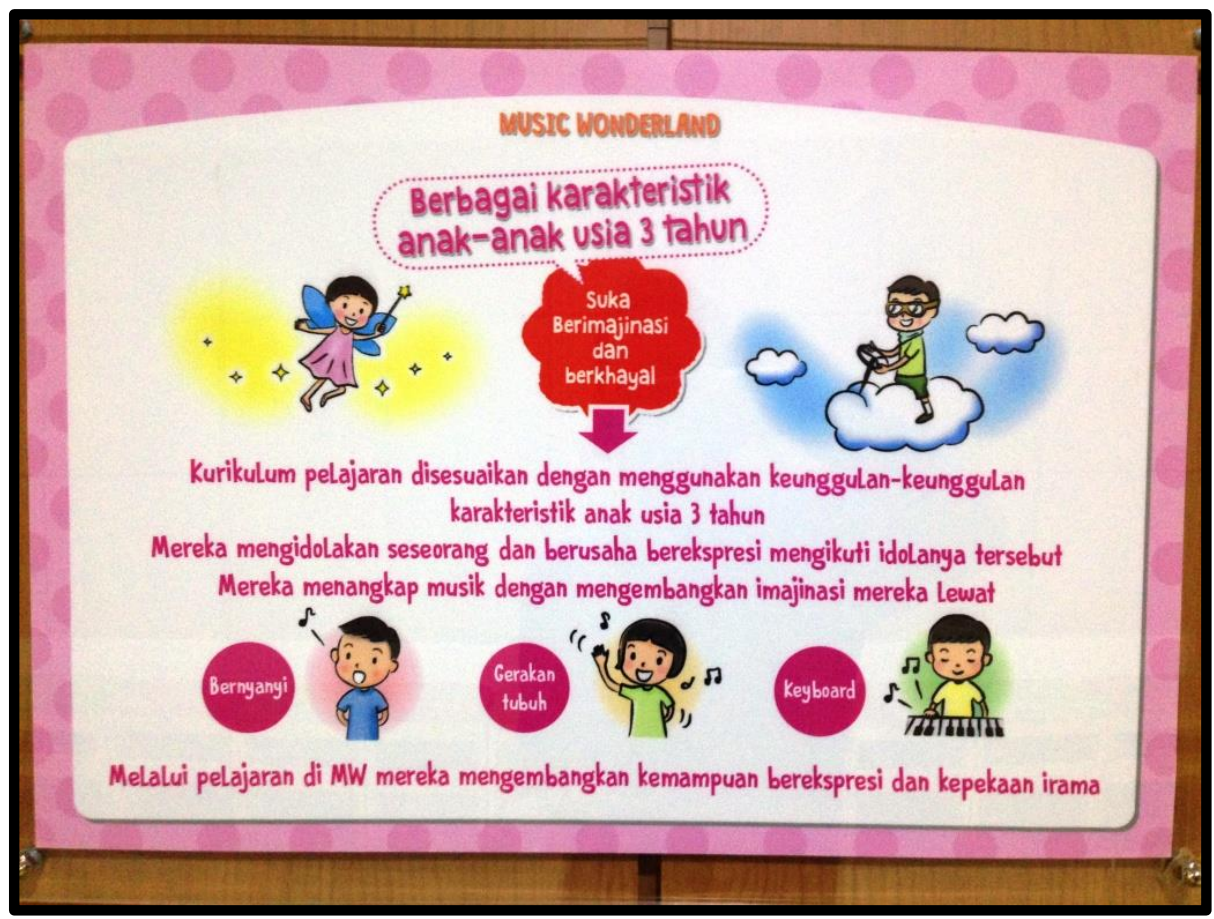

Gambar 12. Poster mengenai Music Wonderland

(Dokumentasi 2016, oleh Didi Hermanto) 


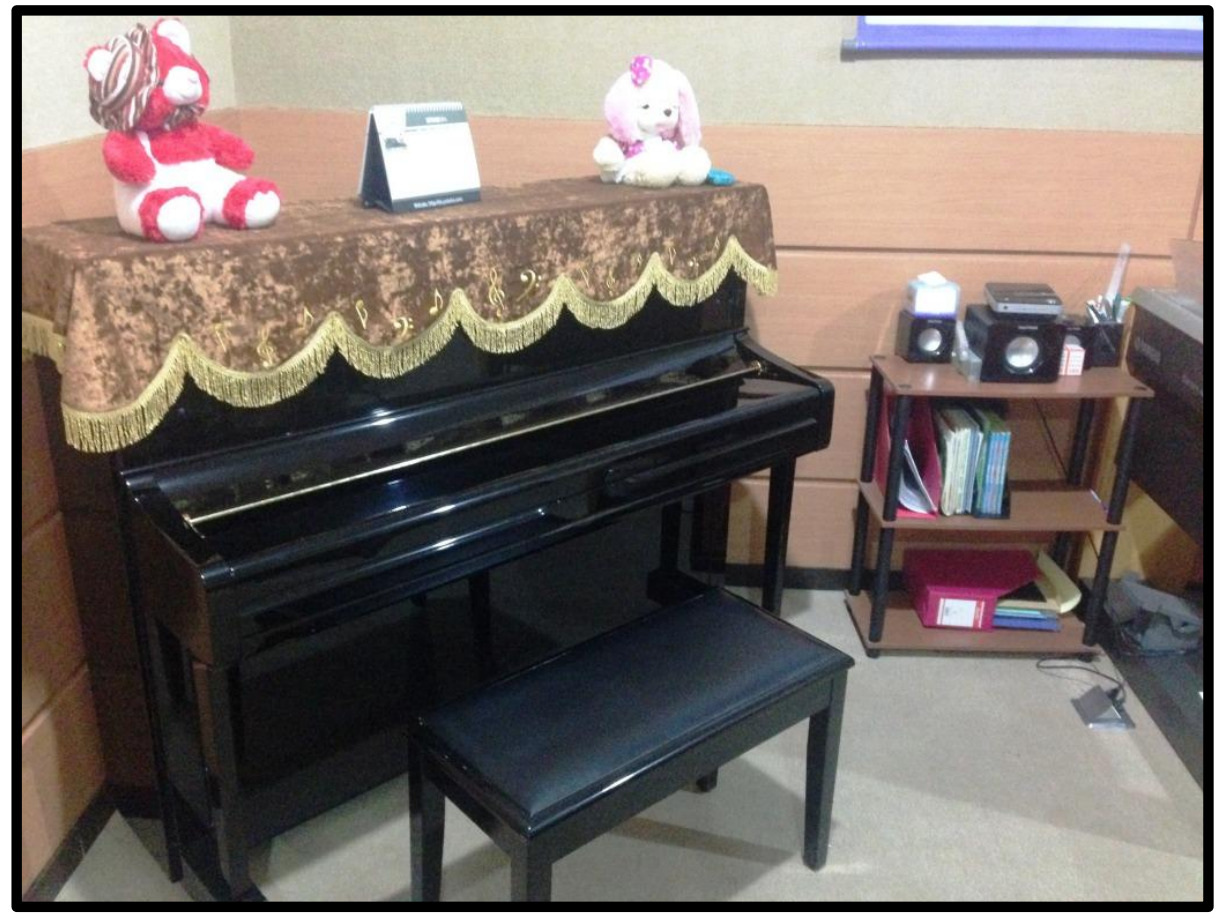

Gambar 13. Piano untuk mendukung kegiatan Music Wonderland (Dokumentasi 2016, oleh Didi Hermanto)

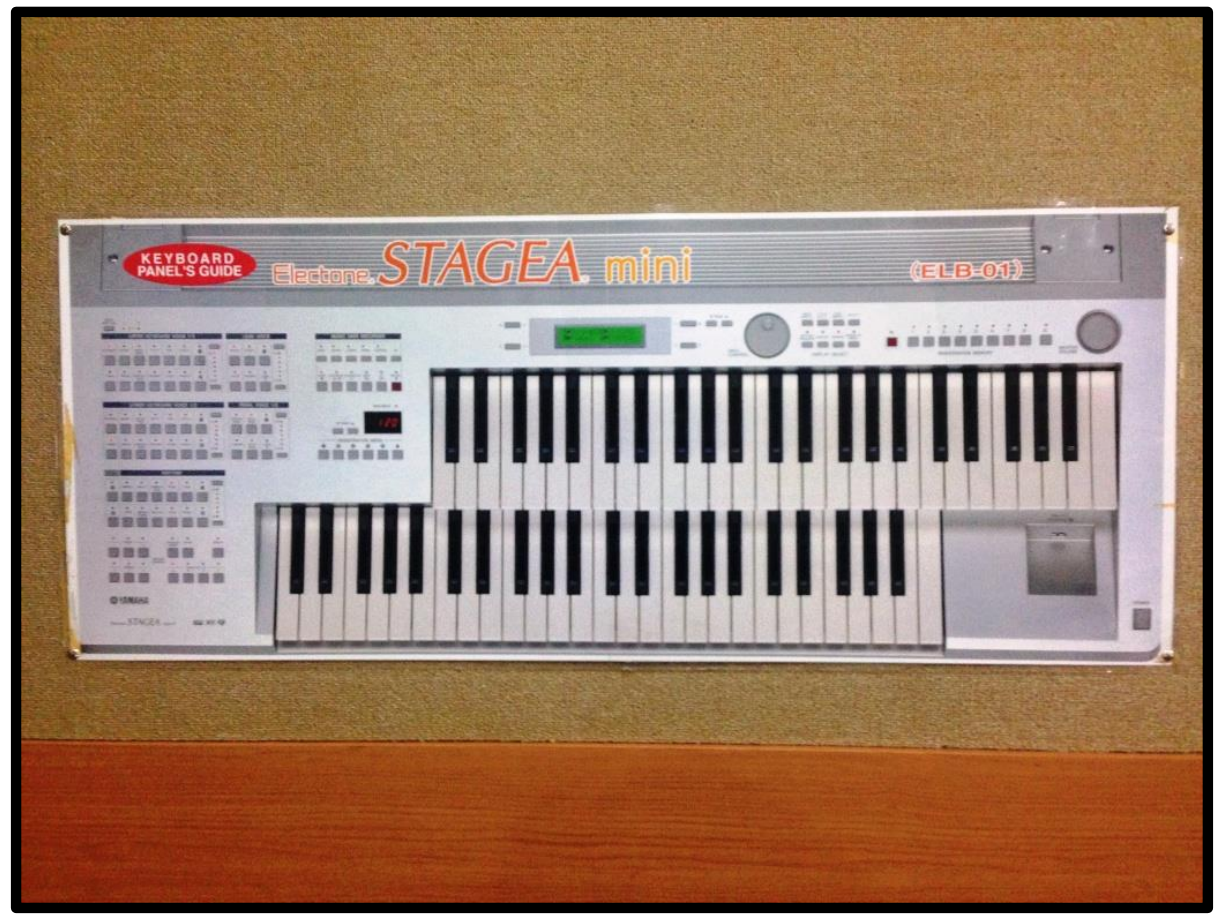

Gambar 14. Media pendukung di kelas Music Wonderland (Dokumentasi 2016, oleh Didi Hermanto) 


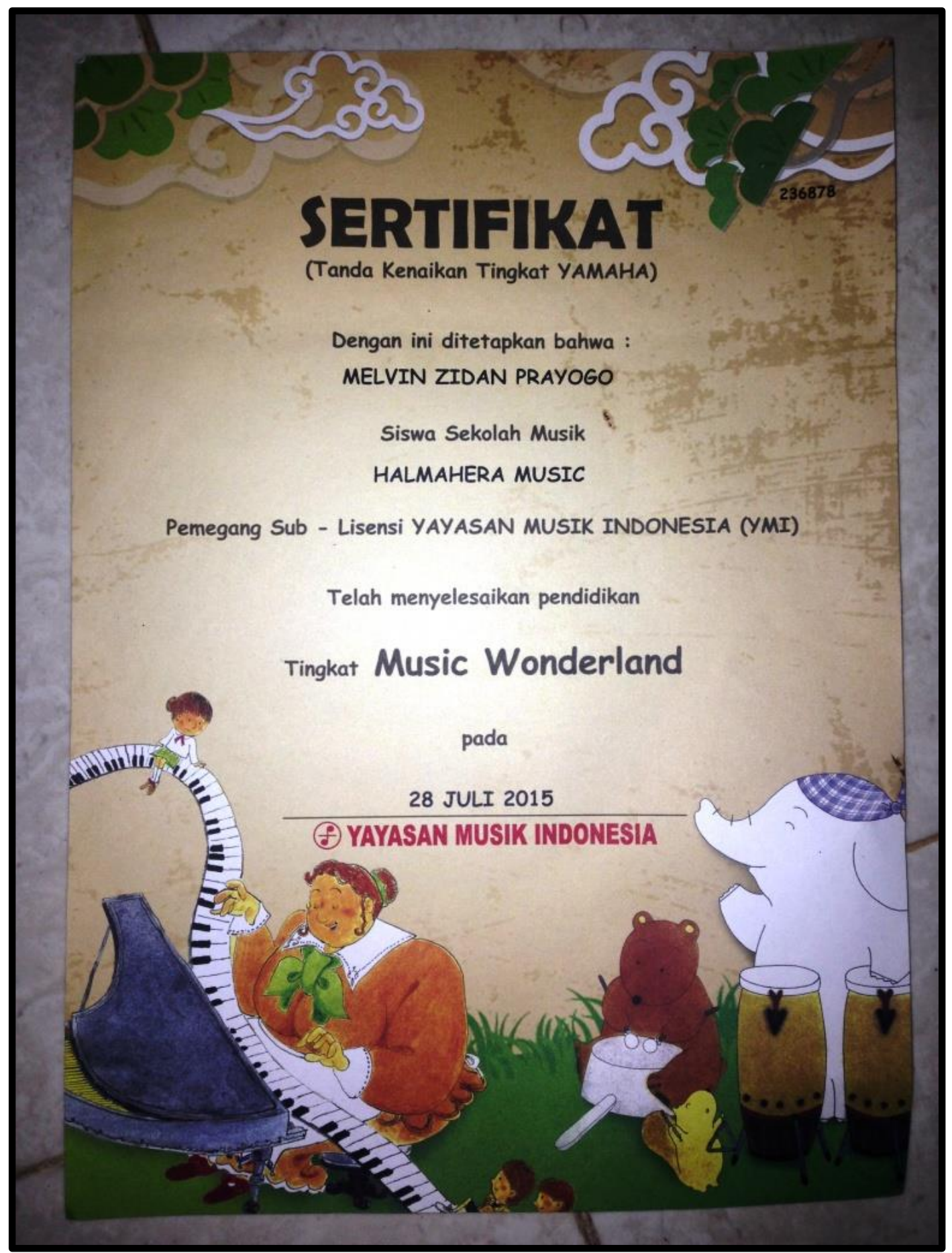

Gambar 15. Foto Sertifikat setelah menempuh program Music Wonderland (Dokumentasi 2016, oleh Didi Hermanto) 


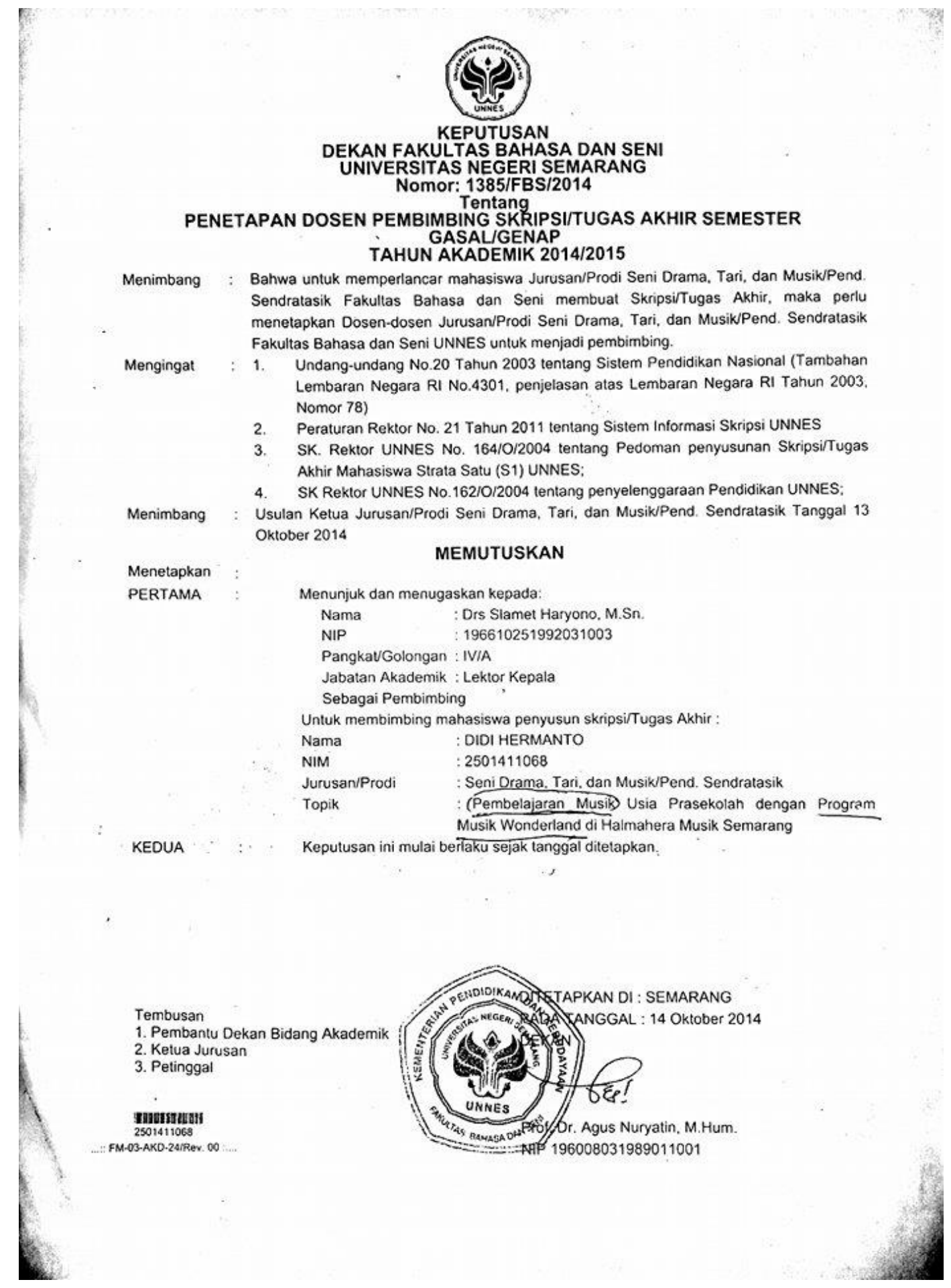




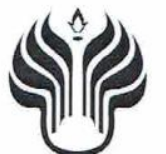

KEMENTERIAN RISET, TEKNOLOGI, DAN PENDIDIKAN TINGGI UNIVERSITAS NEGERI SEMARANG

FAKULTAS BAHASA DAN SENI

UNNES

Gedung B, Kampus Sekaran, Gunungpati, Semarang 50229

Telepon +62248508010, Faksimile +62248508010

Laman: http://fbs.unnes.ac.id, Email: fbs@unnes.ac.id

Nomor : :3047/UN37.1.2/LT/2016

Lamp. : :

Hal. : Permohonan Izin Penelitian

Yth. General Manager Halmaher Music School Semarang

di tempat

Dengan hormat kami beritahukan bahwa dalam rangka penyusunan skripsi mahasiswa kami,

nama : Didi Hermanto

nim :2501411068

jurusan : : Pendidikan Seni Drama Tari dan Musik

program studi : : PENDIDIKAN SENI MUSIK

jenjang : :S1

tahun akademik : 2016/2017 judul : Metode Pembelajaran Musik Dengan Program Musik Wonderland di Halmahera Music School

akan mengadakan penelitian di Halmahera Music School Semarang, waktu pelaksanaan Juli 2016 s.d September 2016 . Untuk itu kami mohon Saudara berkenan memberikan izin kepada mahasiswa di atas untuk keperluan tersebut.

Atas perhatian dan kerja sama Saudara, kami sampaikan terima kasih.

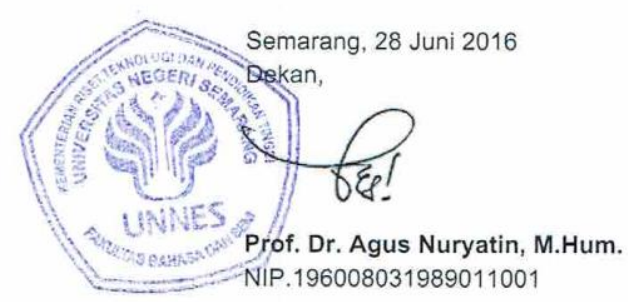

Tembusan:

1. Pembantu Dekan Bidang Akademik

2. Ketua Jurusan

3. Pertinggal 


\section{Wه}

Hal: Surat Perijinan Penelitian

Yth. Dekan Fakultas Bahasa dan Seni

Universitas Negeri Semarang

di Kota Semarang

Dengan hormat kami sampaikan bahwa dalam rangka penyusunan skripsi mahasiswa:

Nama : Didi Hermanto

NIM $\quad: 2501411068$

Jurusan $\quad$ : Pendidikan Sendratasik

Jenjang : :S1

Judul : Pembelajaran Musik dengan Program Music Wonderland di Halmahera Music School Semarang

menyetujui adanya penelitian di:

Tempat : HALMAHERA MUSIC SCHOOL

Alamat : Jalan Achmad Yani 193 Kota Semarang

Waktu : Senin, 5 September 2016

Demikian surat perijinan dari kami, mohon dapat dipergunakan sebagaimana mestinya, atas perhatian dan kerjasama Bapak/lbu kami sampaikan terima kasih.
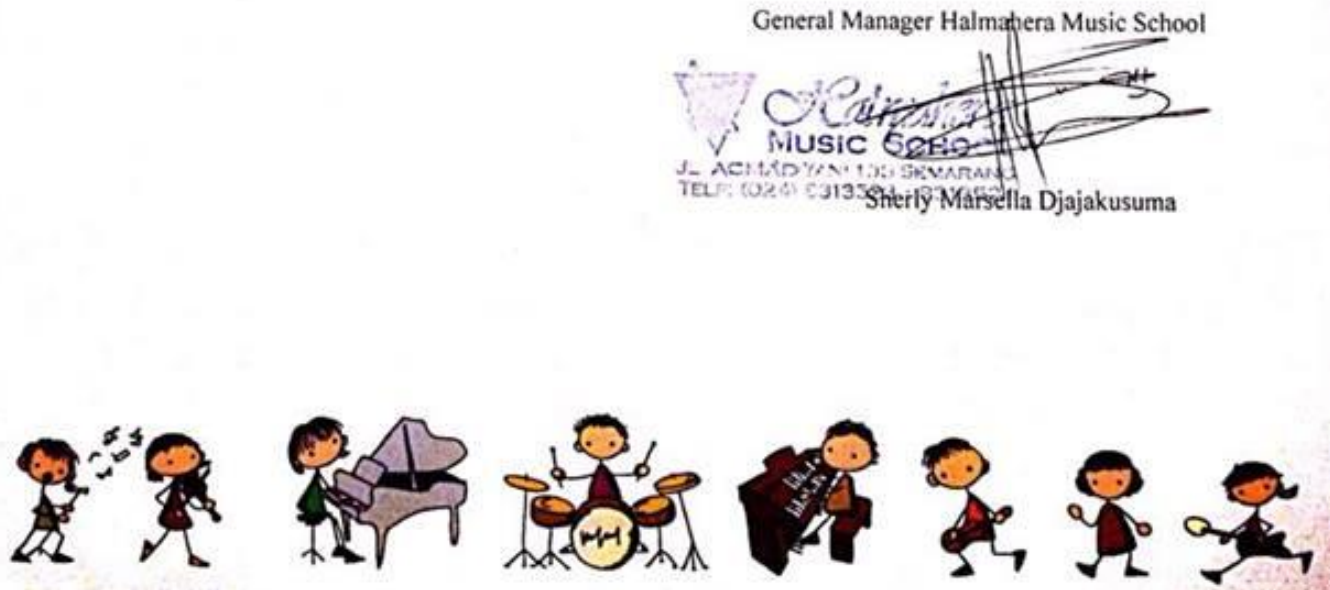
